UNIVERSIDADE DE SÃO PAULO

FACULDADE DE FILOSOFIA, LETRAS E CIÊNCIAS HUMANAS

DEPARTAMENTO DE LINGUÍSTICA

ELIANE DOMANESCHI PEREIRA

Crer e Saber:

UM ESTUDO SEMIÓTICO

Versão corrigida

SÃO PAULO

2013 


\title{
Crer e saber: \\ UM ESTUDO SEMIÓTICO
}

\begin{abstract}
Dissertação de Mestrado apresentada ao Programa de Pós-Graduação em Semiótica e Linguística Geral do Departamento de Linguística da Faculdade de Filosofia, Letras e Ciências Humanas da Universidade de São Paulo, para a obtenção do título de Mestre em Linguística.
\end{abstract}

Área de concentração: Semiótica e Linguística Geral Orientador: Prof. Dr. Waldir Beividas

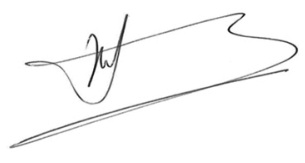

Versão corrigida

SÃO PAULO

2013 
Nome: PEREIRA, Eliane Domaneschi

Título: Crer e Saber: um estudo semiótico

Dissertação de Mestrado apresentada ao Programa de Pós-Graduação em Semiótica e Linguística Geral do Departamento de Linguística da Faculdade de Filosofia, Letras e Ciências Humanas da Universidade de São Paulo, para a obtenção do título de Mestre em Linguística.

Aprovado em: 2013

Banca Examinadora

Prof. Dr. Waldir Beividas

Instituição: Universidade de São Paulo (USP)

Julgamento: Assinatura:

Prof. Dr. Ivã Carlos Lopes

Instituição: Universidade de São Paulo (USP)

Julgamento: Assinatura:

Prof. Dr. Dilson Ferreira da Cruz Junior Instituição: Universidade Presbiteriana Mackenzie Julgamento: Assinatura: 


\section{Agradecimentos}

À professora Norma Discini, cujas aulas, cursos, palestras e falas sempre foram, desde a graduação, um estímulo sólido e autêntico para que eu avançasse na pesquisa semiótica.

Ao professor Luiz Tatit, cujo didatismo original com que ensina a teoria só perde para a generosidade e alegria com que a compartilha - e pelas contribuições dadas a esta dissertação no exame de qualificação.

Ao Ivã Carlos Lopes, professor na acepção ampla, pelo conhecimento que transmite de forma irrestrita, e em todas as ocasiões, a seus alunos, estando eu aí inclusa - e também pelo que contribuiu para esta dissertação por meio de sua leitura atenta do relatório de qualificação.

Ao professor Waldir Beividas, orientador desde minha iniciação científica, por ter acolhido e apoiado meu tema de pesquisa, tornando minha trajetória acadêmica possível. Por ter me acompanhado ao longo dela, pavimentando-a conceitualmente tanto com as bases da teoria como com os últimos desdobramentos da Semiótica da Escola de Paris. Por, diante disso, ter norteado minha postura enquanto pesquisadora. Pela disponibilidade, o comprometimento e o bom humor. E, finalmente, por ter plantado a semente que deu origem às reflexões contidas neste trabalho - e que guarda o potencial para florescer em outros a virem no futuro.

Aos professores Marcos Lopes, Elizabeth Harkot-de-La-Taille, Jean Cristtus Portela, Dilson Ferreira da Cruz, Renata Mancini, Esmeralda Negrão e Mayra Rodrigues Gomes por terem contribuído para a minha formação em Semiótica e Linguística. 
Aos meus colegas do Ges - Usp, contemporâneos a mim enquanto mestrandos e doutorandos em Semiótica, Conrado Mendes, Nathália Guirado, Kiko Merçon, Paula Martins de Souza, Luis Damasceno, Lucas Shimoda, Carolina Tomasi, Marina Maluli, Guilherme Demarchi, Daniela Bracchi, Taís de Oliveira e Ilca Suzana Lopes, por terem me acompanhado nessa jornada.

Aos meus amigos da Editora Abril, Flávia Martinelli, Lana Bitu, Leo Branco e Cauê Yuiti, pelo apoio incondicional e tático, pelo entusiasmo e carinho com que encaram minha vida acadêmica, sem vocês não teria sido tão divertido.

Ao Cauê Yuiti por, além de tudo, ter diagramado esta dissertação.

Ao meu pai, Hélcio Domaneschi, pelo ímpeto intelectual que desde cedo me apontou a existência de um universo a ser descoberto que vai muito além do que se vê.

Ao Paulo, por todo o amor.

Ao Departamento de Linguística da Faculdade de Filosofia, Letras e Ciências Humanas, por oferecer o programa de excelência em que pude realizar meu Mestrado.

Ao CNPq, Conselho Nacional de Desenvolvimento Científico e Tecnológico, pela bolsa concedida a esta pesquisa, essencial para que este trabalho existisse. 
"O mundo continua, assim como a vida e o espírito, em razão da resistência que nos impõem as coisas dificeis de conhecer. Assim que tudo fosse decifrado tudo se dissiparia, o universo revelado seria tão improvável quanto uma trapaça desvendada ou um passe de mágica do qual já se conhece o segredo.”

(Paul Valéry)

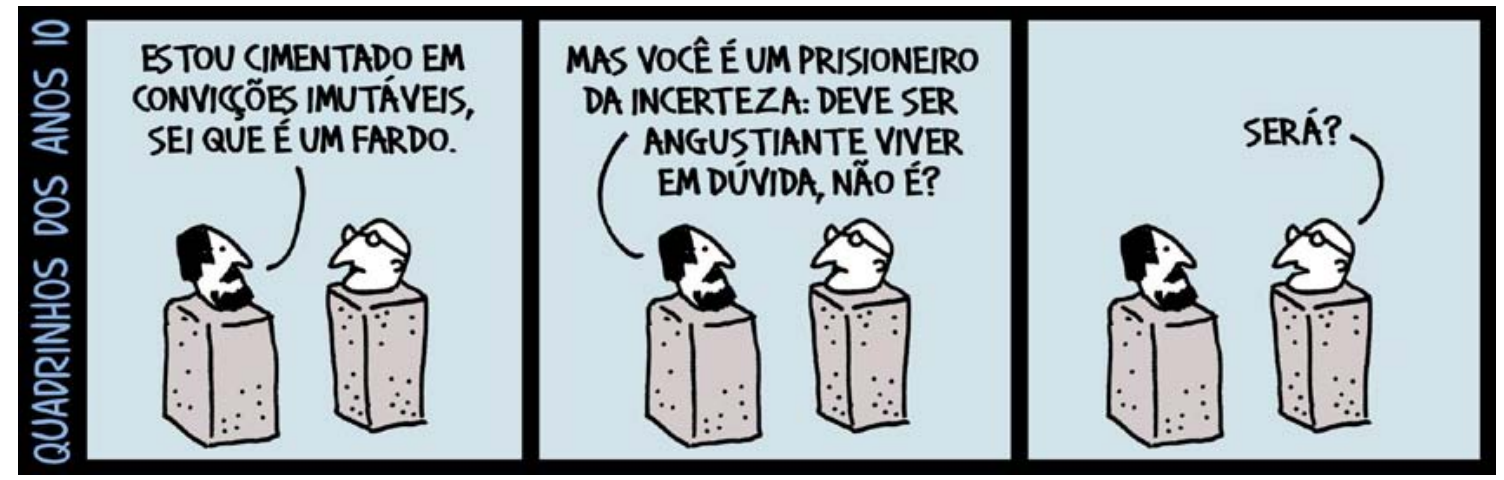

(Andre Dahmer) 
PEREIRA, E. D. Crer e Saber: um estudo semiótico. 2013.163 f. Dissertação (Mestrado) - Faculdade de Filosofia, Letras e Ciências Humanas, Universidade de São Paulo, 2013.

\section{Resumo}

Dentro do domínio teórico da Semiótica da Escola de Paris, o CRER e o SABER são concebidos como modalidades que se articulam em um único e mesmo universo cognitivo e que encontram distinção pelo modo de relacionamento e valorização que estabelecem com o objeto cognitivo. Inicialmente abordadas sob uma perspectiva eminentemente categorial, como a de Greimas (1983), que descreve o ato epistêmico por meio de termos alocados nas categorias previstas no quadrado semiótico e de operações juntivas, elas passam posteriormente por certa reformulação teórica, notadamente a feita por Zilberberg (1988), que privilegia os aspectos tensivos aderidos aos termos. Com base, de forma central, nessas noções, este trabalho tem como objetivo investigar as oscilações tensivas associadas às operações cognitivas do sujeito, o funcionamento, a distinção, a hierarquização e o intercruzamento do SABER e do CRER no interior do fazer interpretativo humano, a incidência do CRER no âmbito da produção de conhecimento e as condições de verdade na ciência enquanto prática discursiva. Para tanto, procuramos fomentar uma discussão teórica acerca desse tema, reunindo, além dos textos paradigmáticos de Greimas e Zilberberg, formulações de outros semioticistas que também se debruçaram sobre a questão do CRER e do SABER, como Fontanille (1982) e (1987), Pottier (1983), Landowski (1983), Coquet (1983) e Geninasca (1983). A fim de ensejar tais reflexões, empreendemos a análise, munidos dos procedimentos metodológicos e das ferramentas de investigação textual providas pelos autores supracitados, de três objetos que põem em jogo as modalidades CRER e SABER, exploram-nas tematicamente e extraem alguns efeitos de sentido de sua oposição, sobreposição, exacerbação, atenuação e falta: o conto Funes, o memorioso (1944), de Jorge Luis Borges, o longa-metragem Doubt (2008), de John Patrick Shanley, e um breve poema recitado por Antonio Abujamra no programa televisivo Provocações. Ao realizarmos este estudo, buscamos ainda fazer face à previsão de Greimas e Courtés, encontrada em seu Dicionário de Semiótica (1979), que aponta o CRER, por sua centralidade no fenômeno humano de produção discursiva, como tema pertinente para a pesquisa semiótica dos anos a virem.

Palavras-chave: crer; saber; modalidades epistêmicas; dúvida; certeza; fé 
PEREIRA, E. D. Believing and Knowing: a semiotic study. 2013. $163 \mathrm{f}$. Dissertação (Mestrado) - Faculdade de Filosofia, Letras e Ciências Humanas, Universidade de São Paulo, 2013.

\section{Abstract}

In the framework of French Semiotics, knowing and believing are conceived as articulated modalities at the same and unique cognitive universe and that can be discriminated by the type of relationship and valuation they establish with the cognitive object. Initially treated by a categorical perspective, as Greimas's (1983), who describes the epistemic act by means of the semiotic square terms and junctive operations, they suffer a theoretical reformulation by Zilberberg, who privileges tensive aspects associated to the terms. Based on these notions, this study aims to investigate tensive oscillations linked to subject cognitive operations, understand in each way knowing and believing operate and cross each other in the cognitive dimension, and also how they can be discriminated and placed on hierarchy. We also intend to discuss how believing takes part in sciences and the conditions of "truth" in science as a discursive practice. Keeping this in mind, we promote a theoretical debate about these modalities, resorting to, besides Greimas and Zilberberg, authors that also thought and wrote about knowing and believing, as Fontanille (1982) e (1987), Pottier (1983), Landowski (1983), Coquet (1983) e Geninasca (1983). In order to give rise to those reflections, and based on the methodological procedures and approach text tolls provided by the aforementioned authors, we undertake the analysis of three objects that thematically explore the modalities knowing and believing and extract some sense effects from their opposition, overlap, exacerbation, attenuation and lack: the short story Funes the memorious (1944), by Jorge Luis Borges, the movie Doubt (2008), by John Patrick Shanley, and a brief poem recited by Antonio Abujamra at a television show named Provocações. By the fulfillment of this study, we also aim to tackle Greimas and Courtés prediction, at their Dictionnaire raisonné de la théorie du langage (1979), that points out the concept of believing, for its centrality at the human phenomenon of discursive production, as a relevant theme for the semiotics research of the years to come.

Keywords: believing; knowing; epistemic modalities; doubt; certainty; faith 
I Apresentação do tema___ 10

II Justificativa e interesse __ 11

III Objetivos — 13

IV Metodologia__ 14

V Estrutura da dissertação _ـ 16

1 EVOLUÇÃO DA TEORIZAÇÃO

SEMIÓTICA ACERCA DO CRER E DO SABER __ 19

1.1 Greimas e o paradigma semiótico:

herança binaria e perspectiva categorial __ 20

1.2 A reformulação de Zilberberg:

da semiótica narrativa à semiótica tensiva __ 23

1.3 As contribuições teóricas de Fontanille (1982) e (1987) __ 27

$1.4 \mathrm{O}$ horizonte de retrospecção teórico __ 47

\section{TENSÃo ENTRE O CRER E O SABER __ 54}

2.1 Os termos em relação - A relação como produtora de diferenças __ 55

2.2 Duas hipóteses em jogo segundo Lopes e Beividas (2009) _ 59

2.3 Contra-hipótese e a questão do CRER no discurso religioso___ 64

$2.4 \mathrm{O}$ ponto de vista de Fontanille __ 67

2.5 Dúvida e percurso transgressivo - uma análise de cena do longa-metragem Doubt__ 74

2.5.1 Prática e ética religiosas: a retenção do percurso transgressivo _ 75

2.5.2 Tensão: a verificação das hipóteses___ 81

\section{As Operações COGNITIVAS___ 93}

3.1 Modalização, tensão e tipologia de sujeitos__ 94

3.2 Crer-SAber, SABER mal e SABER pouco análise de três operações cognitivas em um poema ___ 101

3.2.1 Corpus__ 101

3.2.2 "uma diferença muito grande"___ 102 
3.2.3 Saber mal

3.2.4 Saber pouco

3.3 O CRER na ciência - A questão da aposta

3.4 Enunciação e universo cognitivo:

relações de precedência e hierarquização

\section{Modalização e PercepÇão}

(UNIDADE PRESSUPONENTE E PRESSUPOSTA)

4.1 Linguagem e categorização, modalização e percepção 132

4.2 Apreensão e significação em Funes, o memorioso

4.2.1 Introdução

4.2.2 "Recordo (creio)..."

4.2.3 O cão das três e catorze

4.2.4 A linguagem antes da linguagem

4.2.5 Balanço da análise 


\section{INTRODUÇÃO}

\section{Apresentação do tema}

A distinção entre as modalidades CRER e SABER constitui uma discussão de fundo, já clássica, dentro do domínio teórico da semiótica de linha francesa, pois, como aponta Fontanille (2007, p. 227): "Por um lado, ela traz ao debate muitas outras considerações além daquelas sobre as lógicas significantes do discurso e, por outro, ela supõe a intervenção, no interior da lógica cognitiva, das duas outras dimensões lógicas (ação e paixão)".

Greimas (1983, p. 116) chama a atenção para o fato de que esses dois termos, nas línguas naturais, não somente se sobrepõem sem se confundir, mas chegam a de fato se opor, como podemos observar no exemplo dado pelo semioticista lituano: "Nous savons tous que nous mourrons, mais nous ne le croyons pas". Alexandrescu, em seu artigo "Saying and (Dis)believing" (1983, p. 16), nos fornece outro exemplo flagrante dessa característica dos verbos crer e saber nas línguas naturais ao citar o seguinte trecho do soneto $C X X X V I I I$, de Shakespeare: "When my love swears that she is made of truth, I do believe her, though I know she lies"2 (2005, p. 657).

Concebidos pela semiótica como duas modalidades que se articulam dentro de "um único e mesmo universo cognitivo" (Greimas, 1983, p. 133) e que, de acordo com Fontanille (1999, p. 227), encontram tênue distinção dada pelo "modo de relacionamento e de valorização do objeto cognitivo", o CRER e o SABER convocam a teoria semiótica a refletir e produzir criticamente sobre seu liame e funcionamento no interior das relações intersubjetivas de comunicação.

Encontramo-nos, aqui, no campo de reflexão epistemológica sobre os milenares problemas filosóficos da "verdade" e da "crença”. E os esforços teóricos que se ocupam das modalidades CRER e SABER vêm ao auxílio de tal reflexão. Eles

1 Em tradução livre: Todos sabemos que vamos morrer, mas não acreditamos nisso.

2 Em tradução livre: Quando minha amada jura que é feita de verdade, eu realmente acredito nela, apesar de saber que ela mente. 
também se mostram especialmente relevantes para a teoria semiótica, visto que, no cerne de qualquer situação intersubjetiva de comunicação humana, temos o exercício persuasivo de um FAZER-CRER que conta com, no outro extremo da cadeia comunicativa, o próprio ato de CRER, um ato essencialmente epistêmico.

\section{Justificativa e interesse}

A relevância dos estudos sobre as modalidades no âmbito da teoria semiótica greimasiana parece emergir paulatinamente e de modo crescente no eixo de evolução dessa disciplina. Uma primeira fase em que sua importância entra em evidência aparece descrita no seguinte trecho de Geninasca:

Sabemos como, numa primeira fase, a teoria narrativa centralizou seu interesse na relação Sujeito-Objeto, ligada à sequência central da performance. Só pudemos abordar de maneira útil as sequências extremas, primeira e última, do esquema narrativo canônico, depois de ter reconhecido a autonomia e a importância da dimensão cognitiva das narrativas e enfrentado a questão das modalidades. (1983, p. 118)

Diante, então, da produção de estudos acerca das modalidades, a questão do CRER desponta, posteriormente, como detentora de especial interesse para definição, inclusive, dos rumos para a semiótica enquanto ciência que se propõe a investigar o sentido. É o que observamos no excerto abaixo:

A questão do crer, e portanto da veridicção, está hoje no centro da reflexão semiótica. Das respostas que lhe dermos dependerá, em última instância, o modelo da produção e da comunicação da significação. (Geninasca, 1983, p. 110) 
Esse trecho integra um conjunto de textos produzidos por semioticistas que apontam com igual veemência a centralidade do CRER nos estudos concernentes ao fenômeno da comunicação humana e à construção de um mundo dotado de sentido para os sujeitos. Do conjunto, pode ser considerada expoente a passagem encontrada no Dicionário de Semiótica (2008), de Greimas e Courtés, ao longo da definição dada pelos autores em sua obra para o termo CRER:

De fato, o crer não é somente o fundamento da fé religiosa, mas constitui também e entre outras coisas - certas análises recentes o mostram muito bem - a instância crucial do discurso científico; numa visão mais ampla, o fazer crer, o qual, enquanto fazer persuasivo, não pode ser tratado independentemente do crer, constitui uma das formas principais de manipulação. Sendo assim, a questão do crer aparece como um dos temas de pesquisa semiótica dos anos a virem. (Greimas e Courtés, 2008, p. 107)

É por meio dessas palavras de Greimas e Courtés que nossa pesquisa se pretende explicitamente justificada. Ela também se demonstra engajada e alinhada aos objetivos projetados pelos autores para o futuro da teoria. Encontramo-nos hoje nos "anos a virem” apontados por Greimas e Courtés em 1979, e tomamos como tarefa de nossa dissertação um tema que cabe à semiótica atual abordar: a centralidade do CRER no fenômeno cognitivo humano de construção de "verdades" sobre o mundo. Nesse quadro, buscamos ainda refletir e produzir criticamente acerca dos valores de "crença" e "verdade", voltando-nos também às questões retóricas, em que os mecanismos da persuasão desempenham papel fundamental.

Desse modo, propõe-se aqui um estudo das modalidades CRER e SABER dentro do campo de conhecimento da semiótica da Escola de Paris, procurando-se dar resposta à seguinte questão de partida: "Seria possível ao sujeito efetivamente saber algo sobre o mundo?". Em nossa pesquisa, privilegiaremos a abordagem tensiva das modalidades, como encontrada no modelo teórico zilberbegiano, porém, sem abandonar a pertinente contribuição que a teoria semiótica narrativa, de caráter categorial, desenvolveu em termos de gramática modal que subjaz aos movimentos cognitivos do sujeito. 


\section{Objetivos}

De modo geral, os objetivos deste trabalho podem ser resumidos em três frentes:

a) Identificar os movimentos tensivos presentes na narrativa do longametragem Doubt (2008), de John Patrick Shanley, em estreita ligação com o jogo modal entre CRER e SABER que se dá no interior do fazer interpretativo dos sujeitos, buscando demonstrar a pertinência e os possíveis desdobramentos da hipótese de Lopes \& Beividas (2009, p. 447): "O crer tensiona e o saber distensiona. Mais e mais crer, maior tensão; mais e mais saber, maior distensão, estando nas valências intermediárias e 'elásticas' desses vetores a nossa situação geral de homens sem garantia de verdade".

b) Lançar mão de um protocolo de análise que leva em consideração a modalização, o modo de presença (Fontanille e Zilberberg, 2001, p. 134) e aspectos tensivos (tonicidade, ritmo, andamento) do sujeito para estabelecer a diferenciação entre três tipos de sujeitos identificados em um poema recitado por Antonio Abujamra ao final do programa televisivo Provocações; a partir do arranjo CRER-SABER, encontrado no poema, discutir possibilidades de precedência e hierarquização entre os termos e analisar as condições de verdade na ciência, que, afinal: é UT SABER? É UT CRER? É um CRER-SABER?

c) Trazer elementos da fenomenologia para a abordagem e análise da etapa que precede a modalização do sujeito: a sua percepção do fenômeno, no conto Funes, o memorioso, de Jorge Luis Borges. Sabendo-se que o sujeito constrói o objeto com sua percepção e, ao fazê-lo, constrói a si mesmo como sujeito desta percepção, buscar-se-á na sucessão percepção seguida de modalização também o que pode ser depreendido sobre a identidade do sujeito sob análise. As elaborações teóricas próprias da fenomenologia servirão ainda para fomentar a discussão concernente ao estatuto linguageiro da própria percepção: como ver sem nomear? É possível ver o que não está categorizado pela linguagem? Esse é 
um campo onde a percepção disputa com a linguagem uma primazia, problema para o qual semiótica e fenomenologia ainda não encontraram solução.

\section{Metodologia}

Aspectos próprios ao funcionamento do CRER no interior da comunicação humana suscitam algumas reflexões de implicação metodológica e epistemológica para a semiótica, enquanto disciplina, por parte de Landowski. Esse semioticista abre seu artigo "Sincérité, confiance et intersubjectivité" (1983) afirmando o seguinte:

Partiremos de uma observação banal: no âmbito da comunicação cotidiana, da qual a semiótica notadamente se propõe a dar conta, podemos constatar (...) que nem sempre é necessário se justificar racionalmente para ser acreditado: "Poupe-me de suas explicações, eu confio inteiramente em você"; e nem, por vezes, provar o que se diz é o suficiente para se fazer crer: "Você claramente tem razão, mas eu não acredito em você”. (Landowski, 1983, p. 161)

Diante do que essas afirmações contêm de paradoxal, Landowski aponta, então, que:

(...) é preciso, portanto, encontrar, em um nível intermediário entre o formalismo lógico e o substancialismo psicológico, um outro sistema explicativo, capaz de dar conta - em termos racionais, e não metafísicos - daquilo que nos leva efetivamente à confiança ou à esperança, para "além daquilo a que a lógica nos autoriza". É à semiótica narrativa que recorreremos para tentar construir esse nível intermediário, que põe primordialmente em jogo - esta é nossa hipótese - diversos dispositivos da sintaxe actancial. (1983, p. 162) 
O pendor analítico e metodológico de Landowski à sintaxe actancial pode ser justificado pelo momento em que esse artigo é produzido, quando uma semiótica tensiva de fato ainda não existia. A pertinência desse tipo de abordagem, porém, mesmo hoje, não se perde. Ao fugir das explicações lógicas acerca da linguagem e da comunicação, ela atende ao modo de funcionamento do discurso, que não é um sistema lógico, mas sublógico, como apontado e defendido por Hjelmslev em La catégorie des cas (1972).

Esse aspecto encontra-se patentemente exemplificado pela coexistência das proposições "Poupe-me de suas explicações, eu confio inteiramente em você" e "Você claramente tem razão, mas eu não acredito em você"(Landowski, 1983, p. 161). Ele também é destacado no Dicionário de Semiótica (2008), de Greimas e Courtés, que, ao justificarem a impertinência da lógica em determinada relação ${ }^{3}$ na estrutura elementar da significação, destacam que: "Na linguística, as coisas se sucedem de outro modo: aí o discurso conserva traços das operações sintáticas anteriormente efetuadas" (2008, p. 402) e, por isso, "qualquer identificação apressada dos modelos semióticos com os lógico-matemáticos só pode ser perigosa” (2008, p. 404).

$\mathrm{O}$ afastamento dos parâmetros lógicos para empreendermos a investigação a que nos propomos, que forçosamente encampa a análise de noções como a "verdade", os "saberes", o "conhecimento" e o "real", é um gesto metodológico e epistemológico próprio à semiótica em relação à abordagem de seus objetos. Como Fontanille (1982, p. 5) destaca, enquanto que para a lógica "a avaliação do crer e do saber é limitada à sua relação com a verdade, ou seja, a um sistema de dois valores, não hierarquizável", para a semiótica, "essa avaliação só pode se fundar nas relações de adequação, internas ao enunciado”.

3 A relação é entre os termos contrários "oui" (s1) e "non" (s2), diante dos contraditórios "non" (s2) e "si" (s2). O que rege a distribuição desses termos no quadrado semiótico não é uma questão lógica, visto que o termo "si" é naturalmente equivalente a "oui". Porém "si" comporta, e aí observamos o caráter sublógico da linguagem, "sob a forma de pressuposição implícita, uma operação de negação anterior" (Greimas e Courtés, 2008, p. 402). Assim, "si" não é contrário a "non", mas é a sua negação, o seu termo contraditório, como demonstrado em:

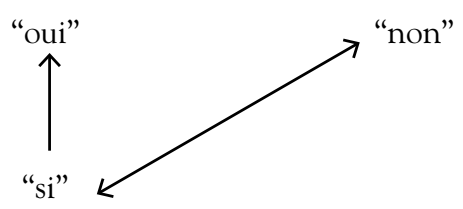


Além disso, em nossa metodologia de análise, buscamos atender outros dois princípios, contidos no seguinte excerto de Greimas: o descarte de domínios semânticos pré-estabelecidos como próprios ao CRER ou ao SABER; e a postura de análise imanente, que toma a linguagem como forma, e não substância, e, ao fazê-lo, afasta-nos do "substancialismo psicológico" também desaconselhado por Landowski:

Existiriam domínios semânticos privilegiados que seriam - exclusivamente ou somente em parte - recobertos por redes fiduciárias de crença, enquanto outros domínios estariam reservados às ciências? À primeira vista, o crer parece se exercer, ao menos no universo ocidental, sobre um território que corresponde grosso modo à religião, à filosofia e à poesia, e que se ocupa essencialmente dos "fins primeiros e últimos do homem". Porém, se retornarmos ao exemplo da emergência do simbolismo, percebemos que este se desenvolveu justamente no momento em que a ciência pretendia dar respostas aos problemas metafísicos, ou seja, o momento quando os dois domínios do saber e do crer se sobrepuseram e se entrecruzaram (...). Dito de outra forma, não é tal ou tal substância de conteúdo que determina a relação cognitiva que o sujeito mantém com ela, mas, ao contrário, a forma do conteúdo: somente o exame das formas de organização do universo cognitivo pode nos informar sobre a parte que aí ocupam o saber e o crer. (Greimas, 1983, p. $125-126)$

Desse modo, primeiramente, analisaremos os princípios expostos por nosso arcabouço teórico tendo como plano de fundo os estudos já feitos no âmbito da reflexão sobre as modalidades CRER e SABER. Trabalharemos, então, de acordo com o método hipotético-dedutivo. Em seguida, por ocasião da análise de nossos objetos, verificaremos de que maneira se encontram com a teoria utilizada e quais são as particularidades encontradas. Nessa etapa, o procedimento respeitado será o empírico-indutivo. A abordagem do corpus de análise será acionada pelos pressupostos teóricos contidos na base teórica sugerida, tendo-se sempre em mente os objetivos definidos em a), b) e c). 


\section{Estrutura da dissertação}

Assim, ao longo do capítulo 1 desta dissertação, apresentamos o tratamento teórico dispensado pela semiótica da Escola de Paris ao nosso tema de pesquisa. Tomamos como formulações centrais, que constituem nosso arcabouço teórico, o texto paradigmático de Greimas "Le savoir et le croire: un seul univers cognitif", capítulo de Du Sens II (1983), a posterior reelaboração tensiva que a abordagem dos termos CRER e SABER recebe por parte de Claude Zilberberg, em sua obra Raison et poétique du sens (1988), o artigo de Jacques Fontanille "Un point de vue sur 'croire' et 'savoir' - Les deux systèmes de l'adéquation cognitive" (1982), e a parte I de Le savoir partagé - Sémiotique et théorie de la connaissance chez Marcel Proust (1987), obra também de autoria de Jacques Fontanille. No último item desse capítulo, 1.4 "O horizonte de retrospecção teórico", reunimos ainda alguns pontos de determinadas teorias que contribuíram historicamente para que a questão do CRER o do SABER se constitua como um objeto de pesquisa para a semiótica hoje.

No capítulo 2 , introduzimos a questão da tensão aderida às modalidades sob análise, cujo ponto de partida é a defesa de Greimas (1983) de que entre CRER e SABER não teríamos uma dicotomia, tampouco uma relação de oposição polarizada entre termos, mas uma gradualidade. Lançamo-nos, então, à investigação sobre esse tópico teórico ancorada essencialmente nos conceitos explanados ao longo do capítulo 1 e à verificação da hipótese central do artigo de Lopes e Beividas (2009), segundo a qual o CRER tensiona e o SABER distensiona.

Já no capítulo 3, voltamo-nos às operações cognitivas empreendidas pelo sujeito quando modalizado de acordo com um CRER ou um SABER. Buscamos compreender de que maneira os modos de presença, como definidos por Fontanille e Zilberberg (2001), podem estabelecer ligação com operações dessa natureza e destacamos a estreita relação encontrada entre modalização e delineamento da identidade do sujeito. É a partir de tal relação que procedemos à caracterização tensiva de três sujeitos construídos discursivamente em nosso objeto de análise, o poema recitado por Abujamra no programa Provocações: o que crê-SABER, o que sabe mal e o que sabe pouco - evidenciando o papel central que as quantificações assumem para determinação de uma identidade. 
É ainda nesse terceiro capítulo que, a partir da diferença de generalidade e possibilidade de hierarquização dos termos que o arranjo "CRER-SABER" suscita, lançamo-nos à análise e ao debate das condições de "verdade" encontradas no âmbito da ciência enquanto prática discursiva. No rescaldo dessa discussão, trazemos à baila possibilidades de organização hierárquica do CRER e do SABER, baseando-nos na precedência que o CRER deteria junto à enunciação, prioridade sintática apontada por Greimas (1983) e referendada por Fontanille (1987), e na diferença de generalidade contraída pelos termos, como defende Fontanille (1987). Para o autor, o CRER seria o termo marcado, enquanto o SABER, o não marcado, e por isso eles não ocupariam o mesmo nível no percurso gerativo de sentido.

Finalmente, no capítulo 4, a partir das noções de apreensão, significação, stase e estetização desenvolvidas pela semiótica da Escola de Paris, e valendonos de algumas elaborações teóricas próprias da fenomenologia, notadamente a de Husserl, empreendemos a análise do conto Funes, o memorioso, de Jorge Luis Borges. Esse texto foi escolhido como objeto de análise por nos apresentar o sujeito de percepção sobre-humana e memória prodigiosa Funes, que instaura a expectativa de ser aquele que de tudo sabe. Porém, o que nos parece ser o aspecto mais inquietante desse conto, originalmente publicado em 1942, e que suscitou o desenvolvimento da análise ora apresentada, é o fato de que essa excepcional percepção do mundo por Funes e sua acumulação enciclopédica de informações, em vez de torná-lo um gênio, faz com que o memorioso paralisese diante dos fenômenos que o cercam, renegue a linguagem, feneça e morra. Desse modo, por meio da abordagem semiótica de seu percurso narrativo, e dispensando-se maior atenção ao modo de apreensão que Funes estabelece com o mundo discursivizado, busca-se melhor compreender qual é a natureza do liame entre apreensão e significação e também entre memória e linguagem. 

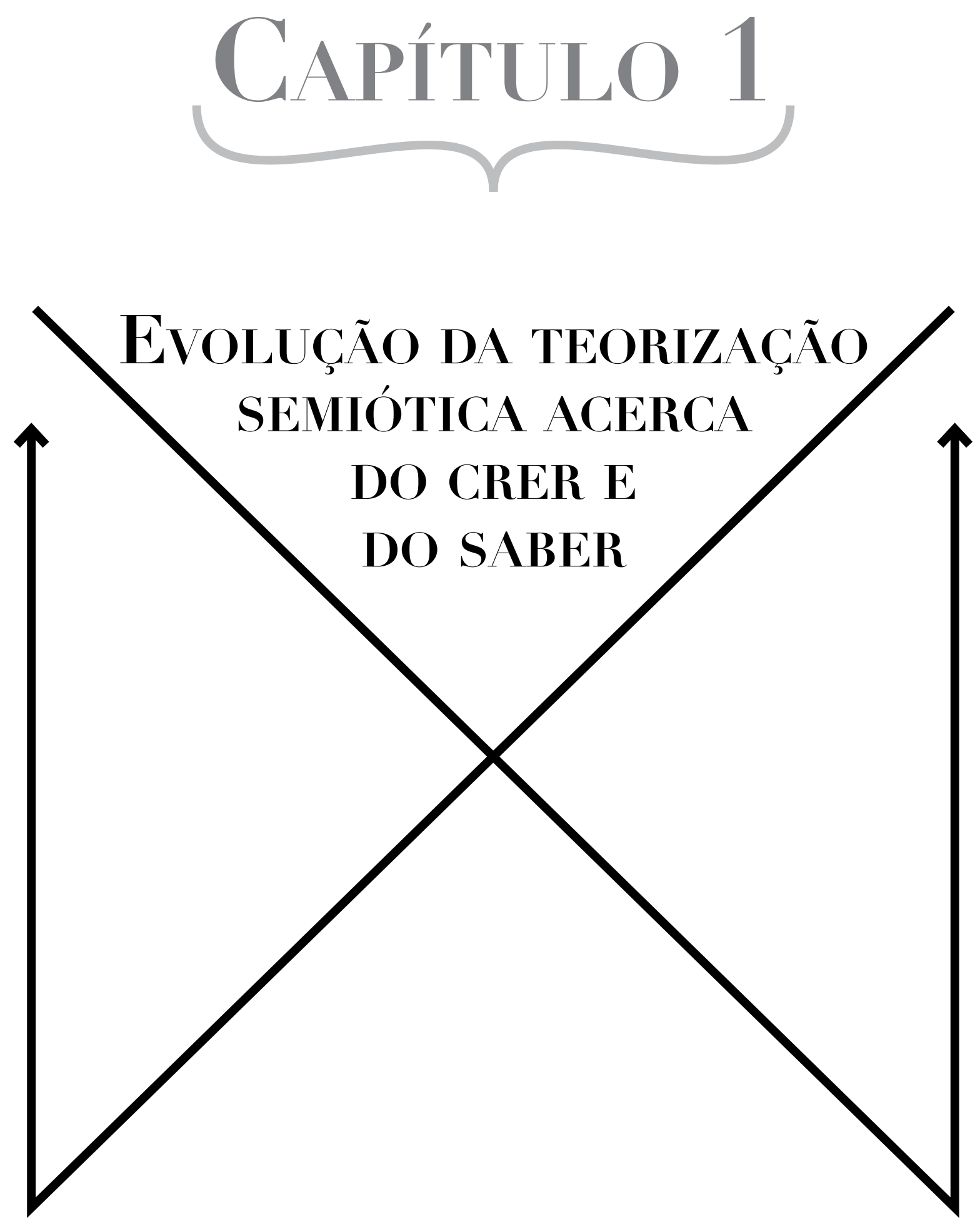


\subsection{Greimas e o paradigma semiótico: herança binária e perspectiva categorial}

O texto de Greimas "Le savoir et le croire: un seul univers cognitif", capítulo de Du Sens II (1983), possui conteúdo paradigmático em relação ao tratamento teórico dispensado pela semiótica da Escola de Paris às modalidades CRER e SABER. Nele, o autor aborda tais modalidades em termos predominantemente categoriais, ou seja, alocadas nas categorias previstas pelo quadrado semiótico. Isso configura e caracteriza um primeiro momento da teoria acerca da questão, como descrito no seguinte trecho de Lopes e Beividas:

Numa primeira fase da teoria, é consensual dizer que o "ponto de vista" lançado sobre o modo de construção da significação dos discursos foi incidente no seu aspecto "gerativo" e descrito sob as relações de contrariedade e contradição acionadas pelo quadrado semiótico. Podemos dizer, resumidamente, que o universo das modalidades do saber e do crer foi descrito em termos "categoriais", isto é, alocado nas categorias previstas no quadrado semiótico. (2009, p. 446)

\section{Da estrutura binária à estrutura quaternária expandida}

O modelo teórico da estrutura elementar da significação, ou quadrado semiótico, é um elemento central no paradigma semiótico greimasiano e em grande parte responsável pela fecundidade e alcance da teoria de Greimas. De fato, desde a sua elaboração, nos anos 1960, o quadrado semiótico, como ferramenta para a abordagem e análise textual, vem sendo amplamente empregado pela patente reprodutibilidade de análise que garante enquanto método científico de pesquisa.

No momento em que Greimas formula sua teoria, nos anos 1960 (Semântica Estrutural data de 1966), as ideias estruturalistas estavam no auge. E uma das heranças articuladas por Greimas na fundação de seu paradigma, como afirma Zilberberg (2006, p. 95), é a herança do Círculo de Praga. Associado a nomes como N. Trubetzkoy, R. Jakobson e A. Martinet, o Círculo de Praga empreendeu 
estudos fonéticos e fonológicos dos quais Greimas herda a estrutura de oposições fonológicas binárias desenvolvida por Jakobson. As estruturas de oposição são denominadas binárias porque trabalham com dois termos que se distinguem pela presença/ausência de um só traço. As oposições fonológicas qualitativa (A vs. B) e privativa (A vs. ̃) dão origem aos termos da primeira geração do quadrado semiótico, respectivamente os termos contrários (oposição qualitativa, como em "dia" vs. "noite") e os contraditórios (oposição privativa, como em "dia" vs. "não-dia”). Já os termos da segunda geração, complexo, neutro e dêixis, obedecem à lógica das oposições participativas, onde termos extensivos (mais vagos) e intensivos (mais precisos), de acordo com definição de Hjelmslev, se relacionam. De forma geral, temos, no quadrado semiótico, uma perspectiva estrutural em que as relações dão sentido aos termos.

\section{Herança binária e perspectiva categorial}

Um primeiro aspecto que nos interessa ressaltar é que as relações de contrariedade e contradição encontradas no quadrado semiótico instituem oposições polares entre os termos. Esse aspecto polarizador pode ser identificado na postura teórica predominantemente categórica assumida por Greimas em relação ao CRER e o SABER em alguns trechos de seu texto de 1983 "Le savoir et le croire: un seul univers cognitif", mas, como veremos mais a seguir, não norteia de forma exclusiva a sua reflexão sobre o tema.

Podemos constatar o aspecto categorial da abordagem de Greimas quando o semioticista afirma, por exemplo, que "o crer por vezes repousa, e até mesmo se consolida, sobre a negação de um saber" (1983, p. 116), "O saber precede o crer" (1983, p. 117), "O crer precede o saber" (1983, p. 122), "O ato epistêmico pode assim ser representado em sua dupla face como uma afirmação ou uma recusa, o que nos autoriza, por sua vez, colocá-lo no quadrado" (1983, p. 119):

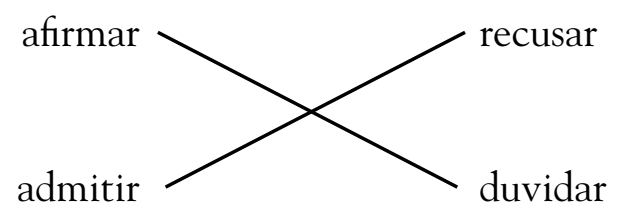

(Greimas, 1983, p. 120) 
É possível, aqui, depreender uma perspectiva categorial que aloca o CRER em oposição ao SABER, ambos em posições polares sobre um mesmo eixo ${ }^{4}$. Assim, o CRER se consolida sobre a negação de um SABER, e o SABER, por sua vez, sobre a negação de um CRER. A noção de precedência (do SABER em relação ao CRER, e vice-versa) também nos permite vislumbrar a abordagem categorial: se uma lógica de precedência organiza os termos, não existe possibilidade de ocorrência simultânea de CRER e SABER.

\section{A intuição do gradual no categorial}

$\mathrm{O}$ ato epistêmico, para Greimas, guarda inicialmente algo de oposição binária ao ser concebido como "uma afirmação ou uma recusa" e posteriormente desdobrado nos termos contraditórios observados no quadrado anterior. Mais adiante, porém, Greimas, ao apresentar o ato epistêmico como uma operação juntiva, chama atenção para o fato de que as modalizações epistêmicas devem ser entendidas como graduais e não categoriais: "Sendo as modalizações epistêmicas graduais e não categóricas (como é o caso, por exemplo, das modalizações aléticas), /afirmar/ e /recusar/ não podem ser considerados senão como polarizações extremas das operações juntivas, bem-sucedidas (= conjunção) ou fracassadas (= disjunção)" (1983, p. 120), como podemos observar em:

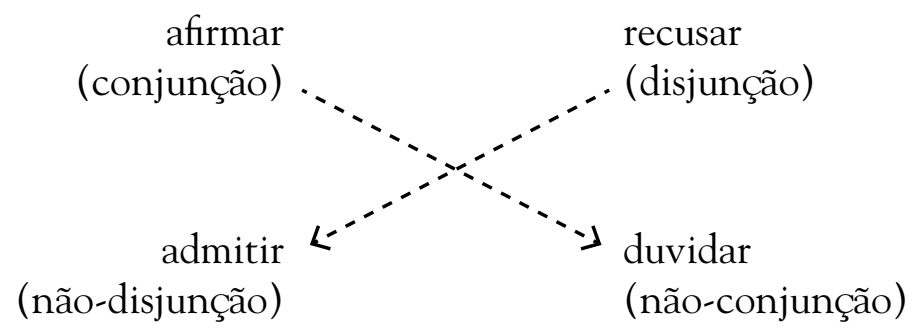

(Greimas, 1983, p. 120)

É importante observar que, nesse ponto de seu texto, Greimas dá ênfase ao caráter gradual das modalidades epistêmicas ao contrastá-las às modalidades aléticas, de aspecto categorial, em que um DEVER-SER, uma vez projetado no quadrado semiótico, engendra os termos s1 necessário, s2 impossível, s1 contingente e $\overline{\mathrm{s} 2}$ possível. O caráter eminentemente categórico das modalidades

4 É preciso ter em mente que, apesar de Greimas realizar uma distinção categorial entre CRER e SABER, ele defende que esta não pode ser praticada como uma dicotomia. 
aléticas pode ser exemplificado pelo fato de que não se considera algo mais ou menos impossível, e sim possível ou impossível, em uma oposição essencialmente polarizada.

Assim, se de modo geral a abordagem de Greimas em "Le savoir et le croire: un seul univers cognitif" privilegia a perspectiva categorial ao descrever o ato epistêmico por meio de termos alocados nas categorias previstas no quadrado semiótico e de operações juntivas, de modo mais específico, e sobretudo quando se volta às modalidades epistêmicas, podemos identificar na postura teórica do semioticista lituano a preocupação em apontar e ressaltar a importância do aspecto gradual que dirige e organiza tais operações do fazer cognitivo do sujeito.

Ao postular que "/afirmar/ e /recusar/ não podem ser considerados senão como polarizações extremas das operações juntivas”, Greimas deixa entrever, avant la lettre, o que posteriormente reconheceríamos como uma formulação tipicamente zilberberguiana, em que os termos são colocados em pontas de um gradiente (tensivo) e comportam inúmeras posições intermediárias (gradações) entre si.

\subsection{A reformulação de Zilberberg: da semiótica narrativa à semiótica tensiva}

De fato, é Zilberberg quem, em Razão e poética do sentido, texto de 1988, procede a notória reformulação concernente à teoria semiótica a partir das bases já lançadas e consolidadas por Greimas para a disciplina. Sabe-se que, em sua origem e momentos iniciais, a semiótica ocupou-se predominantemente do esquema narrativo canônico (caracterizando-se, assim, como uma "semiótica narrativa"), em que o sujeito, manipulado por um destinador e dotado de determinadas competências, vai em busca de seus objetos, com os quais se relaciona de acordo com uma lógica juntiva (que institui conjunções ou disjunções), e percorre, dessa maneira, as três etapas da fórmula mínima de produção de sentido nas narrativas: manipulação, ação e sanção. Nesse contexto, privilegiava-se a abordagem dos conteúdos inteligíveis com a finalidade de verificar como se dava a construção de sentido nos textos e havia certo interesse pela operacionalização do modelo semiótico. 
Entretanto, com o avanço da teoria, surge a necessidade de dar tratamento teórico à dimensão sensível aderida aos discursos, ou seja, faz-se necessária certa reformulação teórica para que os conteúdos passionais possam também ser semiotizados e, portanto, descritos, analisados e compreendidos enquanto elementos geradores de sentido.

Zilberberg, então, mantém-se dentro do paradigma greimasiano, mas o ajusta e articula, formulando um modelo que tem como objetivo dar conta de um aspecto não centralmente discutido ou mais profundamente elaborado no texto de Greimas: os conteúdos sensíveis aderidos ao discurso, ou seja, o investimento afetivo do sujeito em sua relação com seus objetos ou com outros sujeitos, dimensão tímica indissociável de qualquer tipo de produção discursiva.

Tal reformulação é notadamente um dos objetivos centrais do texto de Zilberberg, como ressalta Tatit ${ }^{5}$ na apresentação da edição brasileira de Raison et poétique du sens: "Este livro é uma das respostas dadas à grande questão semiótica surgida no curso da década de 1980: como abordar os conteúdos sensíveis ao lado dos conteúdos inteligíveis já então previstos pelo modelo de Algirdas-Julien Greimas?”. Uma perspectiva mais ampla que caracteriza mais detidamente tal demanda por reformulação teórica, além de situá-la em relação a seu momento histórico, pode ser encontrada no seguinte trecho de Beividas:

Uma formulação feliz caracteriza com propriedade o movimento interno das pesquisas semióticas nas últimas duas décadas. É a que Landowski nos apresenta - não importa aqui o grau de seu engajamento nela - quando, na abertura do texto "Le corps de la nouvelle" de G. Marrone, atesta a situação "como se de um século a outro tudo o que era verbo se tivesse feito carne" (2000, p. 5). O texto deixa de ser "ponto de partida" e "ponto de ancoragem de nossas vociferações" sobre o sentido, sobre a semiose - como pleiteava vivamente Greimas, nos anos 70 e 80, juntamente com sua famosa expressão: "fora do texto não há salvação" (hors du texte, pas de salut) (1987, p. 302 - 311) (...) A problemática da narratividade, das modalidades, da discursivisação, figurativização... - todas elas congruências estruturais fortemente amarradas à substância mesma do discurso (de papel) - vê-se transportada para a arena onde o discurso toma corpo, literalmente, faz-se carne, a exigir reflexão mais centrada na sensibilização, na percepção (interoextero-proprioceptiva), na tensividade ou na foria (...). (2003, p. 45)

5 Em nota de apresentação na orelha da edição brasileira de Raison et poétique du sens, publicada em 2006 pela Edusp, com o título Razão e poética do sentido e tradução de Ivã Carlos Lopes, Luiz Tatit e Waldir Beividas. 
Zilberberg, então, em seu texto de 1988, debruça-se, mormente ao longo do capítulo "Reconhecimento do espaço fiduciário", sobre o mesmo problema teórico abordado por Greimas em "Le savoir et le croire: un seul univers cognitif": a questão do CRER e do SABER. Ao fazê-lo, como já apontamos, mantémse sob o paradigma de Greimas, compartilhando com este a metalinguagem, os conceitos e procedimentos teóricos, especialmente a articulação de termos no quadrado semiótico. Porém, adota uma perspectiva tensiva, em oposição à perspectiva categorial privilegiada pelo semioticista lituano; e, de modo específico às modalidades por nós analisadas, reformula a noção de Greimas de ato epistêmico como uma operação juntiva entre um sujeito e um objeto.

Como já observamos, para Greimas, o "ato epistêmico" (de saber algo ou conhecer algo) é concebido como uma transformação cognitiva ou processo, como uma operação juntiva, onde o SABER precede ou até mesmo expulsa o CRER, e vice-versa. Já Zilberberg define a consistência do saber como "uma isotopia propriamente cognitiva, cujo objeto seria, de certo modo, a relação" (Zilberberg, 2006, p. 161). Afirma também que "as estruturas cognitivas são gerais por sua forma e universais por seu objeto. Por forma, entendemos o quadrado semiótico em sua versão tensiva, fórica":

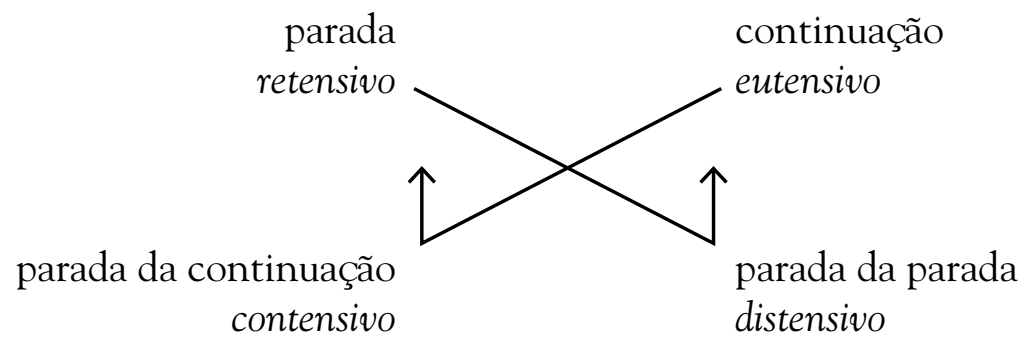

(Zilberberg, 2006, p. 161)

Dessa maneira, Zilberberg redefine a dimensão cognitiva já em termos tensivos. Em Greimas (1983, p. 133), o universo cognitivo é entendido como "uma rede de relações semióticas formais entre as quais o sujeito epistêmico seleciona as equivalências das quais necessita para acolher o discurso veridictório", mas não é apresentada uma solução ou esquematização visual para tal definição e o ato epistêmico é concebido em termos de relações de conjunção ou disjunção, estas, sim, esquematizadas em quadrados.

Ao apresentar a forma da estrutura cognitiva como a própria versão tensiva do quadrado semiótico, Zilberberg atualiza, sob uma perspectiva tensiva, um 
dos sentidos que podem ser depreendidos da definição de universo cognitivo de Greimas. Isso é feito por meio de uma solução esquemática e visual que se torna, então, uma ferramenta teórica para a abordagem dos conteúdos sensíveis.

Essa abordagem se torna possível porque, sobre o quadrado tensivo que representa a forma (geral) das estruturas cognitivas, é depositado um novo quadrado, que articula os termos s1 /escapar/, s2 /compreender/, s1 /apreender/ e $\overline{\mathrm{s} 2}$ /espantar-se/, relativos ao que Greimas denominaria "ato epistêmico" do sujeito, ou seja, à ação do sujeito para conhecer, apreender, compreender, saber etc., algo sobre seu mundo. Desse modo, a cada termo encontra-se já aderido um conteúdo tensivo (provido pelo quadrado tensivo observado na página anterior). A estrutura final constitui o que Zilberberg define como o "quadrado da cognição":

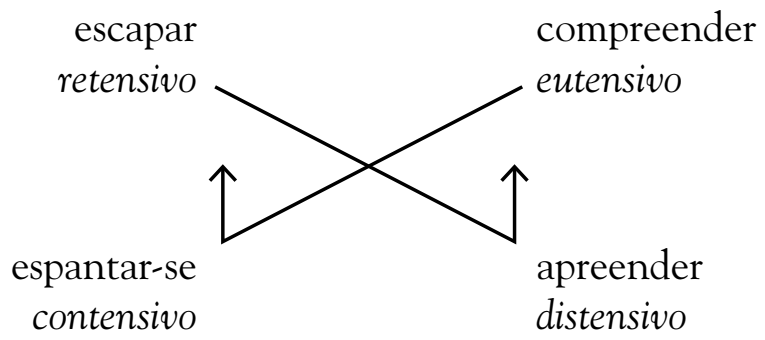

(Zilberberg, 2006, p. 162)

Ao definir o objeto cognitivo como, "do ponto de vista figural, uma relação" (Zilberberg, 2006, p. 161), este autor também postula que, nessa relação, o sujeito pode estar ativado em relação ao objeto (quando o compreende) ou apassivado em relação a ele (quando se espanta com o novo), por exemplo. Isso reformula a noção de que o ato epistêmico opera por meio de operações juntivas de um sujeito com seu objeto, como visto em Greimas (1983). Ou seja, para Zilberberg, ao conhecer o mundo, o sujeito oscila por gradientes tensivos, onde já se encontram aderidos conteúdos tímicos, em vez de se alocar em uma categoria polarizada (conjunto ao objeto ou disjunto). Abaixo, apresentamos um exemplo de esquematização de um percurso do sujeito em "atividade fiduciária", de acordo com Zilberberg:
compreender
espantar-se
escapar
sujeito ativado
sujeito apassivado
não-conjunção
objeto ativado
disjunção

(Zilberberg, 2006, p. 163) 
Finalmente, parece-nos importante ressaltar que, assim como Lopes e Beividas (2009, p. 446) afirmam, "o ponto de vista tensivo vem a complementar e, por vezes, retificar o ponto de vista gerativo/categorial”. Entendemos, portanto, que a reformulação tensiva elaborada por Zilberberg não caracteriza o final dos anos 80 como um momento de substituição ou descarte de um conjunto de noções e procedimentos teóricos em benefício de outros, mas como um estágio de complexificação e enriquecimento da teoria semiótica. Esta, então, passa a contar também, de forma geral, com as ferramentas tensivas como dispositivos de análise textual, podendo, assim, engajar-se na tarefa de quantificação e análise dos afetos aderidos às produções discursivas e, em suma, empreender a investigação do inteligível contido no sensível.

\subsection{As contribuições teóricas de Fontanille $(1982)$ e $(1987)$}

Os avanços que a teoria das modalidades, em um momento ainda anterior à reformulação tensiva, conquistou para a melhor compreensão do jogo modal entre o CRER e o SABER no interior dos discursos destacam-se em nosso estudo como importantes vias de abordagem semiótica das referidas modalidades e também por oferecerem pertinentes protocolos e metodologia de análise para o CRER e o SABER, como os encontrados no artigo de Fontanille "Un point de vue sur 'croire' et 'savoir' - Les deux systèmes de l'adéquation cognitive” (1982).

De acordo com Fontanille, o desenvolvimento e a consolidação da teoria das modalidades são elementos que contribuem para a passagem da semiótica narrativa, caracterizada por sua herança proppiana ${ }^{6}$, à semiótica discursiva, como já concebida por Greimas, ambas etapas anteriores à reformulação tensiva, como podemos observar no seguinte trecho de "Conversations avec Jacques Fontanille":

O fim dos anos 80 , uma vez estabelecida a teoria das modalidades, que havia feito a transição entre a semiótica do narrado e a do discurso, é em primeiro lugar o seminário sobre as paixões, a

6 Entendemos como semiótica de herança proppiana aquela que incorporou e, posteriormente, reformulou em sua teoria os estudos de Vladimir Propp reunidos em Morfologia do conto maravilhoso (1928). Nessa obra, Propp se volta à investigação da estrutura narrativa do conto maravilhoso russo buscando, de forma geral, identificar e classificar as variantes e invariantes do narrado. 
virada 'sensível' das pesquisas semióticas, o crescimento em poder das abordagens fenomenológicas, é o momento em que nasce a semiótica que se faz hoje. (Portela, 2006, p. 166)

São justamente de autoria de Fontanille as contribuições teóricas que, ao lado das extraídas de Greimas (1983) e Zilberberg (1988), completam a fundamentação teórica básica de nossa pesquisa. Apresentamos e comentamos brevemente a seguir, portanto, os conteúdos caros à nossa investigação encontrados no referido artigo de 1982 e em Le savoir partagé - Sémiotique et théorie de la connaissance chez Marcel Proust, obra de Fontanille de 1987.

De modo cronologicamente concomitante à estruturação teórica que as modalidades CRER e SABER recebem da parte de Greimas e, posteriormente, Zilberberg, Jacques Fontanille também se volta ao estudo desses termos sob a visada semiótica. $\mathrm{O}$ aspecto concomitante das pesquisas de Fontanille em relação, sobretudo, às de Greimas, exige certa explicação sobre como o caráter paradigmático do texto "Le savoir et le croire: un seul univers cognitif" (1983) pode ser preservado apesar de contar com data de publicação posterior à do artigo “Un point de vue sur 'croire' et 'savoir' - Les deux systèmes de l'adéquation cognitive" (1982), de Fontanille.

Aprecedência (característicainerenteàs teorias consideradasparadigmáticas em uma disciplina) dos estudos de Greimas em relação aos de Fontanille não fica expressa aqui por meio de datas de publicação, mas é notória pelo fato de que, em 1972, é o jovem Fontanille quem, após ter lido Semântica Estrutural (1966), procura Greimas em busca do que ele descreve como "uma teoria do texto que fosse compatível com meus estudos de linguística (...). Um tipo de conciliação entre as ciências da linguagem e as abordagens textuais" (Portela, 2006, p. 162). É a partir, então, da resposta de Greimas, que o convida a ir a Paris, que Fontanille passa a frequentar os seminários ministrados pelo semioticista lituano, onde entra em contato com grande parte das ideias greimasianas posteriormente reunidas na publicação de Du Sens II (1983). Além disso, é sob a orientação de Greimas que Fontanille produz sua thèse d'Etat ${ }^{7}$, trabalho que posteriormente

7 Fontanille, J. Les points de sue dans le discours. De l'épistémologie à l'identification. Thèse d'Etat, Paris, Sorbonne, 1984.

De acordo com Portela (2006, p. 169 - 170), quando Fontanille chegou às mais de 800 páginas escritas para sua thèse d'Etat, Greimas o orientou a editar esse texto, diminuindo sua extensão. Fontanille, então, suprimiu partes de sua tese e guardou esse material. Dele, surgem posteriormente dois livros: Le savoir partagé - Sémiotique et théorie de la connaissance chez Marcel Proust (1987) e Les espaces subjectifs (1989).

Greimas também orientou a tese de troisième cycle de Fontanille, intitulada Consciences et paroles romanesques. Sémiotique littéraire: la dimension cognitive dans La Semaine sainte d'Aragon, de 1979. 
dá origem à obra Le savoir partagé - Sémiotique et théorie de la connaissance chez Marcel Proust (1987).

Desse modo, as elaborações teóricas de Greimas impõem-se como precedentes, e mesmo originadoras e norteadoras, das produções de Fontanille de 1982 e de 1987 que tomamos como componentes da base teórica desta dissertação. A própria escolha dos temas para esses trabalhos, que se concentram sobre a questão do SABER e da dimensão cognitiva, reflete diretamente os conteúdos debatidos nos seminários promovidos por Greimas, como observamos no seguinte trecho em que Fontanille explica por que seus primeiros trabalhos ocuparam-se de tais questões: "Era a questão da atualidade à época, visto que o seminário sobre as modalidades havia acabado de terminar, o número 43 de Langages $^{8}(1976)$ estava publicado e o artigo de Greimas sobre a veridicção ${ }^{9}$ também" (Portela, 2006, p. 164).

De fato, é a ênfase à gramática modal que subjaz às operações intersubjetivas ou interactanciais do sujeito em seu, como definido inicialmente por Greimas, "um só universo cognitivo", que identificamos (e procuraremos demonstrar) como o elemento caracterizador da abordagem feita por Fontanille das modalidades CRER e SABER. Tal ênfase se faz presente tanto no artigo de 1982 quanto no texto de 1987, que parecem ser regidos pelo objetivo geral de extração de uma sintaxe modal pela qual os sujeitos estabelecem valores de "verdade" e "crença" no interior das narrativas.

Podemos observar o estabelecimento dessa meta já nas páginas iniciais de "Un point de vue sur 'croire' et 'savoir' - Les deux systèmes de l'adéquation cognitive" (1982), onde Fontanille afirma que seu artigo visa a: "Isolar as operações discursivas subjacentes à transmissão de conhecimentos" $(1982$, p. 7$)$ e, mais adiante, define o objetivo central de seu texto da seguinte maneira:

Este estudo se detém à caracterização da relação entre /S2 - O/ nos universos do saber e do crer, dito de outra forma, visa exclusivamente à diferenciação modal dos objetos cognitivos, adotando, para

8 Onde encontramos o artigo: Greimas, A. J. "Pour une théorie des modalités". Langages, $10^{\circ}$ ano, $n^{\circ} 43,1976$, p. $90-107$.

9 Greimas, A. J. "Le contrat de véridiction". Man and World, 13/3-4, 1980. (Posteriormente, em 1983, esse artigo foi publicado em forma de capítulo em Du Sens II. 
tanto, uma perspectiva de construção de objetos, que não dispensa, como veremos, a evocação da competência correlata aos sujeitos ${ }^{10}$. (Fontanille, 1982, p. 12 - 13)

Para tanto, o autor lançar-se-á à investigação de modelos de adequação cognitiva, noção central de seu artigo, e que surge a partir da importante distinção inicial que abre o texto:

Para a lógica, a avaliação do saber e do crer é limitada à sua relação com a verdade, ou seja, a um sistema de dois valores, não hierarquizável. Para a semiótica, essa avaliação só pode se fundar nas relações de adequação, internas ao enunciado. (Fontanille, 1982, p. 5)

A seguir, Fontanille fornece, então, uma definição provisória para a adequação cognitiva e apresenta o corpus em que baseará sua reflexão:

Se admitirmos que o fazer avaliativo de um sujeito interpretativo se aplica a determinado enunciado de estado, podemos definir provisoriamente a adequação cognitiva como o conjunto de sobremodalizações aplicadas a esse enunciado, e que constituem a prova qualificante do sujeito interpretativo. Como hipótese, escolhemos essa problemática para descrever os pontos comuns e as diferenças entre o crer e o saber. O corpus escolhido se compõe de quatro Diálogos de Platão: Protágoras, Eutidemo, Górgias e Mênon. (...) Buscam-se nos Diálogos platônicos um ou mais modelos de adequação cognitiva. (Fontanille, 1982, p. 5 - 6)

A escolha desse conjunto de textos de Platão como corpus de seu artigo é justificada pelo fato de que a "arte de Platão", termo empregado pela maior parte dos comentários críticos que acompanham as diferentes edições ${ }^{11}$ para descrever

10 De acordo com Fontanille, existem três operações que formam o sintagma intersubjetivo subjacente às relações de transmissão de conhecimento: entre S1 e S2 (em que S1 é o mestre e S2, o discípulo, por exemplo), onde temos um fazer persuasivo; entre S2 e $\mathrm{O}$ (objeto cognitivo), onde encontramos um fazer epistêmico; e entre S2 e S1, onde há um fazer fiduciário, em que S2 faz um julgamento favorável de S1. Discorremos mais detidamente acerca desses conceitos no item 2.4 "O ponto de vista de Fontanille".

11 A tradução utilizada por Fontanille é a de E. Chambry (Garnier-Flammarion). 
a habilidade de Platão em conduzir as mais áridas discussões filosóficas de modo agradável, consiste essencialmente em "explicitar e descrever as relações intersubjetivas, e mais precisamente as diversas estratégias fiduciárias que permitem aos locutores fazer crer e fazer saber" (1982, p. 6). Em relação ao modo de abordagem de seu corpus, Fontanille sugere o progressivo afastamento da superfície dos textos de Platão a fim de que, então, as operações discursivas que subjazem à transmissão de conhecimento (cuja identificação foi apontada no início deste item como objetivo central do artigo de 1982 de Fontanille) possam ser atingidas e postas em análise.

Por meio dessa estratégia metodológica, Fontanille tece uma sequência de reflexões embasadas nos Diálogos, entendidos como um "inventário empírico que permite destacar uma série de eixos semânticos sobre os quais se opõem os universos axiológicos do 'crer' e do 'saber' em Platão” (1982, p. 11). De fato, o autor distingue sucessivamente em seu corpus relações de oposição de acordo com o conteúdo, o procedimento de aquisição (do objeto cognitivo), a origem do conhecimento, os tipos de relações e figuras dominantes no sintagma intersubjetivo e, a partir disso, apresenta-nos um quadro que, de forma esquemática, descreve o que Fontanille nomeará como dois "universos de racionalidade"12.

\begin{tabular}{|c|c|c|}
\hline & Crer & Saber \\
\hline Conteúdos cognitivos & $\begin{array}{c}\text { crenças } \\
\text { ("conhecimento falso") }\end{array}$ & $\begin{array}{c}\text { ciências } \\
\text { ("conhecimento } \\
\text { verdadeiro") }\end{array}$ \\
\hline Estratégia cognitiva & persuasão & convicção \\
\hline $\begin{array}{c}\text { Origem do } \\
\text { conhecimento } \\
\end{array}$ & $\begin{array}{l}\text { S1 (exterioridade) } \\
\text { por manipulação }\end{array}$ & $\begin{array}{l}\text { S2 (interioridade) } \\
\text { por reminiscência }\end{array}$ \\
\hline Relação ao objeto & $\begin{array}{c}\text { imediata } \\
\text { não aspectualizada }\end{array}$ & $\begin{array}{c}\text { mediata, aspectualizada, } \\
\text { com resistência do } \\
\text { objeto }\end{array}$ \\
\hline $\begin{array}{l}\text { Relação dominante no } \\
\text { sintagma intersubjetivo }\end{array}$ & $\begin{array}{c}\mathrm{S} 2-\mathrm{S} 1 \\
\text { (ligação às pessoas) }\end{array}$ & $\begin{array}{c}\mathrm{S} 2-\mathrm{O} \\
\text { (ligação às ideias) }\end{array}$ \\
\hline Figuras dominantes & $\begin{array}{c}\text { consenso, acordo, } \\
\text { identidade } \\
\end{array}$ & $\begin{array}{c}\text { desacordo, discussão, } \\
\text { alteridade }\end{array}$ \\
\hline
\end{tabular}

(Fontanille, 1982, p.11)

12 Os termos contidos nesse quadro proposto por Fontanille e que não são mencionados nesta explanação inicial encontram-se comentados de forma mais detida ao longo do capítulo 2. 
$O$ fato de que Fontanille postula a existência de dois universos de racionalidade, um referente ao CRER e o outro, ao SABER, pode, em um primeiro momento, sugerir possível discordância epistemológica de seu artigo em relação ao texto paradigmático de Greimas (1983), onde encontramos a definição de "um único universo cognitivo" que abarca ambas as modalidades. Atemos-nos, aqui, a duas evidências textuais, extraídas do artigo de Fontanille (1982), para considerar os dois textos, além de alocados sob o mesmo paradigma semiótico, o fundado por Greimas, como partícipes de um projeto preponderantemente uníssono, e antes caracterizado pela continuidade do que pela ruptura, de construção do universo das modalidades CRER e SABER enquanto objeto de investigação para a semiótica.

A primeira evidência é pontual: Fontanille remete, por meio de uma nota de rodapé, a expressão "universos de racionalidade” ao próprio Greimas, atribuindo a este a autoria do termo, produzido "a respeito dos trabalhos do Professor J. P. Vernant" (1982,p.11).A segunda permeia todo o texto de Fontanille: o semioticista denomina os universos do SABER e do CRER de maneira predominante como "dois universos de racionalidade" (os termos "dois universos de conhecimento" (1982, p. 12), "dois universos axiológicos" (1982, p. 11) e “dois sistemas axiológicos contrários" (1982, p. 9) também são pontualmente empregados) e entendemos que essas noções constituem um movimento de esforço para a especificação do que é encontrado em Greimas de modo mais geral: o universo cognitivo do sujeito.

Dessa maneira, o universo de racionalidade do CRER e o universo de racionalidade do SABER seriam formas englobadas em um único universo cognitivo englobante, arranjo depreensível do texto de Fontanille a partir de uma importante decorrência semiótica extraída do quadro apresentado na página anterior: para o autor, as diferenças entre os universos do CRER e do SABER podem se resumir essencialmente da seguinte maneira:

a) a oposição entre "crer" e "saber" é a homologia cognitiva da oposição geral entre "manipulação" e "ação"; e se trata, de fato, de se distinguir na dimensão cognitiva a relação somente aos objetos da relação aos outros sujeitos e aos objetos;

b) em consequência, podemos supor que a modalização própria aos objetos de crença é o / dever-ser/, porque ela remete à dominação de um outro sujeito (S1), e que a modalização própria aos objetos 
do saber é o / poder-ser/, porque ela remete estritamente ao desejo de domínio cognitivo do sujeito S2 sobre o objeto. (Fontanille, 1982, p. 12)

A decorrência que nos interessa aqui está contida no item b) pois, a partir dela, Fontanille afirma que "todas as diferenças entre os dois universos de conhecimento parecem depender, em profundidade, da relação do sujeito a respeito do conhecimento, uma relação de dominação reversível” (1982, p. 12, grifo nosso):

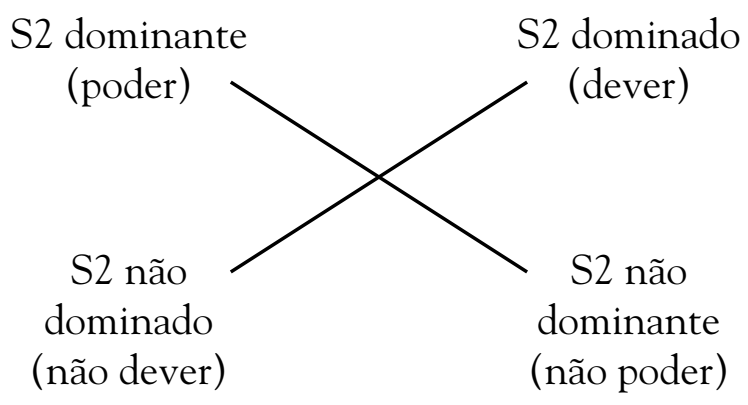

(Fontanille, 1982, p.12)

A reversibilidade, esquematicamente apresentada no quadrado acima, implica, portanto, que um mesmo sujeito, em seu único universo cognitivo (como definido por Greimas), seja capaz de acessar alternadamente os universos de racionalidade do SABER e do CRER (como especificado por Fontanille). Para estruturar seu modelo teórico de maneira que esse duplo acesso fosse esquematicamente representado, Fontanille realiza a homologação dos quadrados das modalidades aléticas /dever-ser/ e /poder-ser/ e, ao projetar nessa homologação as operações cognitivas equivalentes a cada modalização (por exemplo: o poder-ser engendra a operação cognitiva "admitir" no sistema do SABER; o não dever-ser, a operação cognitiva "duvidar" no sistema do CRER), chega à representação do que ele define como a "forma global de interpretação dinâmica das operações cognitivas" (1982, p. 28).

Tal procedimento teórico é detidamente descrito e demonstrado no capítulo 2 desta dissertação, mais especificamente no item 2.4 "O ponto de vista de Fontanille". O que nos é relevante nesse primeiro momento de apresentação das teorias é que entendemos, aqui, que as formulações de Fontanille não interditam ou contradizem o que é defendido por Greimas (1983) em termos de definição e funcionamento das modalidades CRER e SABER. Pelo contrário, Fontanille logra especificar, ao conceber seus dois universos de racionalidade, 
termos que parecem estar subsumidos pelo que Greimas nos apresenta, de modo mais geral, como universo cognitivo.

Um ganho metodológico e que oferece um rico protocolo de análise do jogo entre essas modalidades no interior dos discursos provém do fato de que Fontanille põe os sistemas do CRER e do SABER em relação ao homologar os quadrados que trazem as operações cognitivas correlatas a cada um dos universos, ao postular que esses universos estão no mesmo nível do percurso gerativo de sentido e ao afirmar que eles pressupõem, juntos, um mesmo objeto e um mesmo sujeito cognitivo, suscetível alternadamente ao CRER e ao SABER.

A respeito dessa dinâmica de alternâncias, Fontanille defende que "crenças' e 'saberes' se virtualizam uns aos outros. Quando as operações de adequação são atualizadas em um sistema, elas são virtualizadas no outro" (1982, p. 27). A passagem de um sistema a outro se dá, então, por um percurso transgressivo, outra noção concebida e demonstrada por Fontanille em seu artigo, e que se mostra uma produtiva ferramenta semiótica para a abordagem dos textos, sobretudo daqueles em que a alternância entre o CRER e o SABER no fazer interpretativo do sujeito é especialmente produtora de sentidos. A proficuidade analítica da noção de percurso transgressivo é o que tentaremos demonstrar nas análises apresentadas nesta dissertação nos itens 2.5 "Dúvida e percurso transgressivo uma análise de cena do longa-metragem Doubt" e 3.2 "CRER-SABER, SABER mal e SABER pouco - análise de três operações cognitivas em um poema”.

Da mesma maneira que inicia "Un point de vue sur 'croire' et 'savoir' - Les deux systèmes de l'adéquation cognitive" (1982) fazendo a distinção do modo como lógica e semiótica são capazes de avaliar o SABER e o CRER (respectivamente, uma avaliação limitada à relação dos termos com a "verdade" e, a outra, uma avaliação fundada nas relações de adequação, internas ao enunciado), Fontanille abre o texto Le savoir partagé - Sémiotique et théorie de la connaissance chez Marcel Proust (1987) também diferenciando dois termos: primeiro, o saber compartilhado enquanto "saber posto em comum", que figura como uma concepção da semiologia a respeito do SABER, datada dos anos 60 ou até mesmo de antes disso, quando ela se apoiava na teoria da informação e da comunicação e, consequentemente, quando entendia que o problema do SABER se resumia àquele de sua transmissão entre um destinador e um destinatário e à sua análise em unidades mínimas de informação; e o segundo, o saber compartilhado como "saber dividido, quebrado", que corresponderia à concepção atual da semiótica sobre a modalidade: uma abordagem fundada sobre as operações fundamentais 
da discursivização.

Assim, segundo Fontanille, para a semiótica, a questão do SABER só se coloca, no discurso, a partir do momento em que se observa um desnível entre o SABER do enunciatário e o do enunciador, ou seja, entre o SABER efetivamente enunciado, posto à disposição do enunciatário, e aquele que podemos em princípio supor pertencer ao sujeito da enunciação. $\mathrm{O}$ autor afirma que "para a semiótica, o saber compartilhado entre parceiros da comunicação só é interessante, ou seja, pertinente e observável, se ele for mal compartilhado, deformado, desviado, economizado" (Fontanille, 1987, p. 9) e, sobre os dois tipos distintos de saber identificados, postula:

Em um caso, o saber é um dado quase inerte que se confunde com o conteúdo da mensagem e que em suma é apenas um conteúdo, do qual a mensagem é o contenente, e sobre o qual o único critério de avaliação é a maior ou menor fidelidade em relação ao referente. No outro caso, o saber se torna um desafio possível para as buscas narrativas e para as estratégias enunciativas, justamente porque não se confunde nem com a mensagem que é objeto de uma enunciação nem com o conteúdo do enunciado. (Fontanille, 1987, p. 9)

O autor avança destacando que, apesar de frequentemente ser considerada uma revolução "copérnica" a proposição vinda da filosofia da linguagem de que a linguagem não é apenas feita para transmitir informação, mas também para agir sobre o mundo e sobre os outros, poderíamos na verdade nos perguntar se ela é mesmo feita para transmitir informações: certamente ela o faz, mas manipulando-as, deturpando-as, explorando-as com fins estratégicos "cuja transmissão de informação propriamente dita é apenas um caso particular, quando não um pretexto" (Fontanille, 1987, p. 10).

Isso posto, temos que a semiótica não negligencia o fato de que o SABER possa ser compartilhado "posto em comum", e não somente compartilhado "quebrado". Mas, partindo da hipótese de que "toda enunciação suspende a unidade de saberes enunciados" (Fontanille, 1987, p. 10), a semiótica mostrarnos-á que essa unidade é um objetivo jamais atingido completamente. Nisso, ela não inova, pois retoma na trama de discursos literários, pictóricos, científicos, entre outros, as questões que se colocam a maior parte dos filósofos: como o 
sujeito pode acessar o conhecimento, como ele pode escapar às limitações do seu entendimento e construir uma objetividade no mundo? Aqui, Fontanille chama a atenção para o fato que, se o SABER for considerado uma informação entregue pela mensagem sobre a situação e o mundo, essa questão remete apenas a uma epistemologia externa, submetida aos métodos e aos conceitos da filosofia. Por outro lado, se o SABER for considerado como ocupante de uma das dimensões da semiose, tais questões podem receber ao menos uma nova formulação, senão novas respostas, no quadro de uma epistemologia interna do discurso que, na medida em que obedece ao princípio da imanência, remete à análise semiótica do discurso.

Desse modo, Fontanille define a epistemologia semiótica - ou epistemologia interna - como "o estudo da economia do SABER nos discursos" (Fontanille, 1987, p. 11), quaisquer que sejam eles: não apenas os discursos científicos ou didáticos, entendidos por definição como aqueles que tratam e transmitem os saberes, mas também o discurso literário, a pintura e a escultura, que igualmente manipulam saberes e põem em jogo buscas e estratégias cognitivas. Tal epistemologia tem como objeto, portanto, uma das dimensões da semiose, a dimensão cognitiva, que se opõe às duas outras dimensões: a tímica e a pragmática. E ela deve satisfazer, de acordo com Fontanille, a duas condições complementares: a primeira é precisar o que é o SABER na teoria semiótica de maneira a garantir a sua autonomia, ou seja, de modo que fique provado que o SABER não é somente uma modalidade indissociável dos enunciados modalizados e que detém tipologias e percursos independentes; a segunda e complementar condição decorre do fato de que o questionamento sobre a autonomia da dimensão cognitiva tem, como contraparte necessária, o estudo das dependências e inter-relações que essa dimensão apresenta face às duas outras.

Para tanto, Fontanille realiza, em toda a primeira parte de Le savoir partagé, um inventário da questão do SABER: procede a uma análise do semema /saber/, trata de sua definição, seu lugar e seu papel na semiose. Sobre a análise sêmica do termo, que é caracterizada como "exclusivamente sintática" e que busca "captar o saber antes mesmo do investimento antropomórfico na sintaxe narrativa de superfície" (1987, p. 12) para construir uma primeira definição, em nível mais abstrato, do termo, Fontanille afirma: 
A análise sêmica do /saber/, por mais obsoleta que possa parecer a alguns, e por mais insuficiente que ela seja no que concerne ao método, aos nossos olhos em particular, apresenta, porém, uma vantagem considerável nesse caso: somente ela pode nos salvar da deriva cognitivista; os fundamentos da epistemologia interna não estão nas operações psicológicas dos sujeitos retornaríamos então a uma epistemologia externa -, mas na própria língua, nas estruturas sintáticas dos enunciados elementares. (1987, p. 21)

Assim, Fontanille busca apontar as direções de sua análise para os componentes semânticos e sintáticos particulares que oporiam a natureza da junção cognitiva aos outros dois tipos de junção (tímica e pragmática), visto que a especificidade do núcleo sêmico /saber/, segundo o autor, seria a própria junção cognitiva. A hipótese que sustenta essa abordagem é o fato de que existem, tanto na enunciação quanto no enunciado, três tipos de junção interdefiníveis no seio da teoria semiótica, e que dão conta da totalidade de percursos manifestáveis. Mas avancemos na caracterização dessa modalidade como apresentada pelo autor.

O SABER, para Fontanille, encontra não apenas uma, mas várias definições em semiótica, "que se complementam em certo sentido, mas que não são suficientemente articuladas" (1987, p. 19). Ele destaca que encontramos o SABER tanto nas trocas entre os protagonistas do enunciado quanto nas trocas entre enunciado e enunciatário. No primeiro caso, o SABER é comumente considerado o próprio objeto de circulação da informação e do conhecimento do enunciado que, de forma paralela aos eventos práticos, tece também o desenrolar narrativo. Já no segundo, o SABER parece estar diretamente implicado nos processos de discursivização, na construção da significação, como objeto do próprio fazer semiótico. Mas, seja nas manifestações enuncivas ou enunciativas, o SABER é definido como um "objeto", e até mesmo, no nível abstrato, como um "valor" posto em circulação entre protagonistas do enunciado ou da enunciação.

Enquanto objeto, portanto, Fontanille defende que o SABER tem dois grandes "modos de existência", tanto no enunciado quanto na enunciação: 
(...) distinguimos ordinariamente o operador modal, sob as espécies do "saber fazer" e "saber ser", e o saber objeto de sentido, cujo conteúdo é a unidade de significação que ele pressupõe. Como operador modal, o saber sobredetermina um predicado de base, como é o caso, por exemplo, em uma gramática frasal ou em lógica: o "saber fazer" é pressuposto pela performance narrativa, pela própria ação; e o "saber ser" por um conjunto notável de paixões do sujeito. Como "contenente de sentido", por outro lado, o saber funciona como um vetor no qual o conteúdo é reduzido a uma significação. Transparente ao conteúdo de sentido que veicula, ele se diferencia deste unicamente pelo fato de que põe esse conteúdo em relação com um sujeito. (Fontanille, 1987, p. 20)

Enquanto o SABER como operador modal, pressuposto pela performance narrativa (saber-fazer) e por uma classe de paixões ou existência modal (saberser), é um habitual conhecido da teoria semiótica padrão, a noção de SABER como contenente de sentido, conforme nos é apresentada por Fontanille, introduz uma inovação teórica especialmente cara à nossa análise. Ela traz ao debate semiótico sobre o SABER uma nova dimensão para reflexão, visto que instaura entre "operador modal" e "contenente de sentido" uma diferença que é da ordem classêmica, ou seja, associada a um mesmo núcleo sêmico. Ela produz dois modos de existência do SABER, que não compartilham da mesma posição hierárquica no percurso gerativo de sentido:

Suporemos que a oposição entre esses dois modos de existência é da ordem classêmica, de fato, a distinção entre "operador modal" e "contenente de sentido" pode ser interpretada como uma distinção hierárquica entre os saberes semióticos e os saberes meta-semióticos. (Fontanille, 1987, p. 20 - 21)

Os saberes meta-semióticos, para Fontanille, estão associados ao saber-fazer e saber-ser, operadores modais. $\mathrm{O}$ autor afirma que o "saber-fazer remete a um conhecimento da organização semiótica do fazer" (Fontanille, 1987, p. 31) e que o mesmo pode ser generalizado em relação ao saber-ser. O que temos aqui são saberes que estão em um nível diferente de seus objetos: o saber-fazer é um conhecimento ideal das estruturas narrativas, ou seja, um saber não sobre o conteúdo semântico do fazer, mas sobre as condições ideais de exercício do fazer. A essa altura do texto, Fontanille traça um paralelo saussuriano para enriquecer 
seu argumento: se a langue, em termos de saber, consiste em uma memória social que reúne os mecanismos pressupostos pela parole, ao generalizarmos essa observação para o discurso, lembraremos que aquilo que faz, em semiótica, o papel da langue de Saussure são as estruturas narrativas - e é do conhecimento ideal delas que se ocupam os saberes meta-semióticos.

Por outro lado, os saberes semióticos se relacionam ao saber:fazer e saber:ser. Fontanille elege o sinal gráfico $(:)$ - dois pontos - para diferenciar o SABER contenente de sentido do SABER operador modal, expresso pelo uso do hífen (saber-fazer, saber-ser). O que essencialmente caracteriza o saber semiótico é o fato de que ele se encontra no mesmo nível de seu objeto, e a aquisição de um saber:fazer ou um saber:ser permite a apreensão de conteúdos de sentido. Nas palavras do semioticista:

Se conservarmos a ideia de que aquilo que está no centro da distinção classêmica é a tomada de consciência de uma distância hierárquica, o saber "semiótico" se definirá como um saber no mesmo nível que seu objeto; assim, o saber:fazer supõe que, em um nível "n", o fazer seja um conteúdo de saber para um objeto de mesmo nível; o saber meta-semiótico se definirá como um saber de nível diferente (superior ou inferior) de seu objeto; assim, saber-fazer supõe que em um nível $\mathrm{n}+1$ o fazer seja um objeto de saber a ser construído, e no nível $\mathrm{n}-1$ o fazer seja um objeto de saber a ser analisado. Por exemplo, uma das versões do saber-fazer, o "saber como fazer" pode ser ilustrada da seguinte maneira. Seja, em nível "n”, um programa a ser realizado: se deslocar; "saber como fazer" se refere aqui a construir, no nível " $n+1$ ", uma atitude que permitirá que se sucedam de modo conveniente as etapas, os programas de uso e as aquisições de meios (de locomoção). Inversamente, uma outra versão do saber-fazer, o "saber por que fazer" consistirá por exemplo em analisar o programa a ser cumprido (se deslocar), e em acessar, por exemplo, no nível "n-1", um programa de base e valores mais profundos, como "ir ao escritório" ou "trabalhar". O saber-fazer supõe então que um sujeito cognitivo tenha acesso seja às organizações mais figurativas (diríamos que a um espírito "concreto" e "prático"), seja às organizações mais abstratas (diríamos, então, que ele saiba "ir ao essencial"). (Fontanille, 1987, p. 32)

Para ilustrar o funcionamento do saber semiótico, em nível "n”, junto do saber meta-semiótico, no caso em nível n+1 (objeto de saber a ser construído), em um exemplo prático, Fontanille conta-nos a pequena narrativa: 
(...) ao contar um episódio infeliz de sua vida, que considera representativo de suas atitudes fracassadas, um depressivo explica como ele conseguiu ser demitido sem (receber) indenização de demissão; ao ficar sabendo que sua usina iria fechar, ele entregou sua demissão antes do aviso de demissão, e, portanto, não pôde se beneficiar da cláusula econômica da demissão. Ele sabia "aquilo que estava para ser feito" e que ele iria deixar um emprego, mas ele não soube ordenar convenientemente as etapas, mais figurativas, do percurso de demissão. Ele detinha um "saber:fazer", mas não um "saber-fazer" de nível n+1. (Fontanille, 1987, p. 32 - 33)

Dessa forma, observamos que os saberes semióticos, ou contenentes de sentido, contam com estatuto mais geral (mais adiante, porém, observaremos em um esquema gráfico, na página 43 desta dissertação, que Fontanille posiciona saberes semióticos e meta-semióticos lado a lado no nível classêmico, ficando a diferença hierárquica por conta na notação " $n$ " em relação a “n+1" e "n-1") por promoverem a apreensão de um conteúdo de sentido (objeto de saber) por parte do sujeito, enquanto os saberes meta-semióticos se ocupam de operações de âmbito mais específico, de caráter regulatório, entre outros, relativas ao saberfazer e saber-ser. Em suma, Fontanille considera:

(a) que a aquisição do saber:fazer e do saber:ser permite uma apreensão de conteúdo de sentido, e que ela dá lugar às provas qualificantes "apreensivas"; (b) que a aquisição do saber-fazer permite uma otimização do fazer quando ela concerne um saber de nível " $n+1$ ", e uma finalização do fazer quando ela concerne um saber de nível "n-1", dando lugar respectivamente às provas qualificantes "optimizantes" e "finalizantes"; (c) que a aquisição do saber-ser permite uma regulação das paixões ou uma contenção da atitude; a "regulação" e "contenção" funcionam aqui (...) respectivamente como "ser" e "parecer"; podemos prever as provas qualificantes "contensivas", que afetam mais precisamente a manifestação passional (nível "n+1"), e "regulatórias", que afetam mais precisamente a imanência, ou seja, o ser stricto sensu ("n-1"). (1987, p. 33) 
Para completar sua análise do núcleo sêmico /saber/, que busca garantir a autonomia de tal modalidade na teoria semiótica e, para tanto, demonstrar, entre outros aspectos, a especificidade dos enunciados cognitivos em oposição aos enunciados tímicos e pragmáticos, Fontanille apresenta ainda três distinções. $\mathrm{O}$ autor caracteriza a junção segundo o saber como uma junção noológica. $\mathrm{O}$ aforismo de Sócrates "Só sei que nada sei" ilustra uma particularidade essencial do SABER que constrói seu caráter noológico: a recursividade dos enunciados cognitivos, ou seja, o fato de um enunciado cognitivo poder ser tomado, ele mesmo, como objeto de outro enunciado cognitivo de nível superior, e assim por diante ${ }^{13}$. As construções sintáticas “*A única coisa que posso é que não posso nada", "? A única coisa que quero é que não quero nada" e "*A única coisa que devo é que não devo nada", por serem questionáveis (sinalizadas por *) ou insignificantes (sinalizadas por ?), mostram que as demais modalidades não apresentam a mesma propriedade e, portanto, engendram junções pragmáticas. Em oposição às junções noológicas, que constituem enunciados onde a recursividade sempre tem sentido (seja em séries recursivas reflexivas, com sujeito único, ou transitivas, com diferentes sujeitos), as pragmáticas constituem os enunciados em que a recursividade só tem sentido se for transitiva, ou seja, se os sujeitos forem diferentes.

Além disso, os objetos do saber são considerados discretos: acumuláveis como entidades discretas, eles se diferenciam dos objetos pragmáticos (também discretos) pois sua recursividade permite uma ultrapassagem hierárquica e a síntese de saberes parciais acumulados. De fato, é por causa dessa natureza específica dos objetos de saber que "mesmo pontos de vista excludentes que, por definição, fazem obstáculo a tal reunificação, podem assim ser ultrapassados, englobados, e seus saberes solipsistas reintegrados a um saber homogêneo" (Fontanille, 1987, p. 23). Apesar disso, os objetos do SABER permanecem descontínuos, pois a argumentação do SABER, segundo Fontanille, tem a forma de justaposição ou concatenação, em oposição aos objetos tímicos, contínuos e não discretos, cuja argumentação, ou a diminuição de "atrações" e "repulsões", se faz pelo modo da intensidade, “em uma variação gradual contínua” (Fontanille, 1987, p. 27).

A última distinção, finalmente, dá conta de que os objetos do SABER possuem determinação subjetiva. Fontanille destaca que admitimos correntemente, em semiótica, que o objeto de valor venha em primeiro lugar na relação sujeito-

$13 \mathrm{~A}$ recursividade dos enunciados cognitivos e as consequências que daí decorrem para a organização hierárquica dos sistemas cognitivos são explicadas mais tarde por Fontanille pela noção de hiper-saber. 
objeto, pois é o conteúdo semântico do objeto e o universo de valor ao qual ele faz parte que determina e semantiza todo o enunciado, aí compreendido o sujeito. Mas, em relação a essa precedência, o autor faz a ressalva:

Para o /saber/, parece que é o contrário, visto que tudo pode ser objeto de saber: um fazer, um actante, uma figura, qualquer que seja o conteúdo semântico; ou melhor: se esse conteúdo ainda não é conhecido, ele está para ser atualizado no enunciado, e essa atualização para o sujeito é o próprio jogo da busca cognitiva. Dessa maneira, não é mais aqui o objeto que semantiza o sujeito, mas o sujeito cognitivo que transforma qualquer grandeza em objeto cognitivo. (Fontanille, 1987, p. 28)

Tal transformação empreendida pelo sujeito cognitivo em relação a qualquer que seja a grandeza define a noção de determinação subjetiva dos objetos cognitivos. Por oposição, os objetos tímicos e pragmáticos se caracterizam por sua determinação objetiva, visto que, por definição, são "marcados" em profundidade de forma anterior à sua junção com o sujeito: nesse caso, é o objeto que semantiza o sujeito (seja ele tímico ou pragmático).

Como um resumo dos resultados obtidos por meio de sua investigação sêmica do núcleo /saber/, Fontanille apresenta-nos, então, o seguinte quadro: 


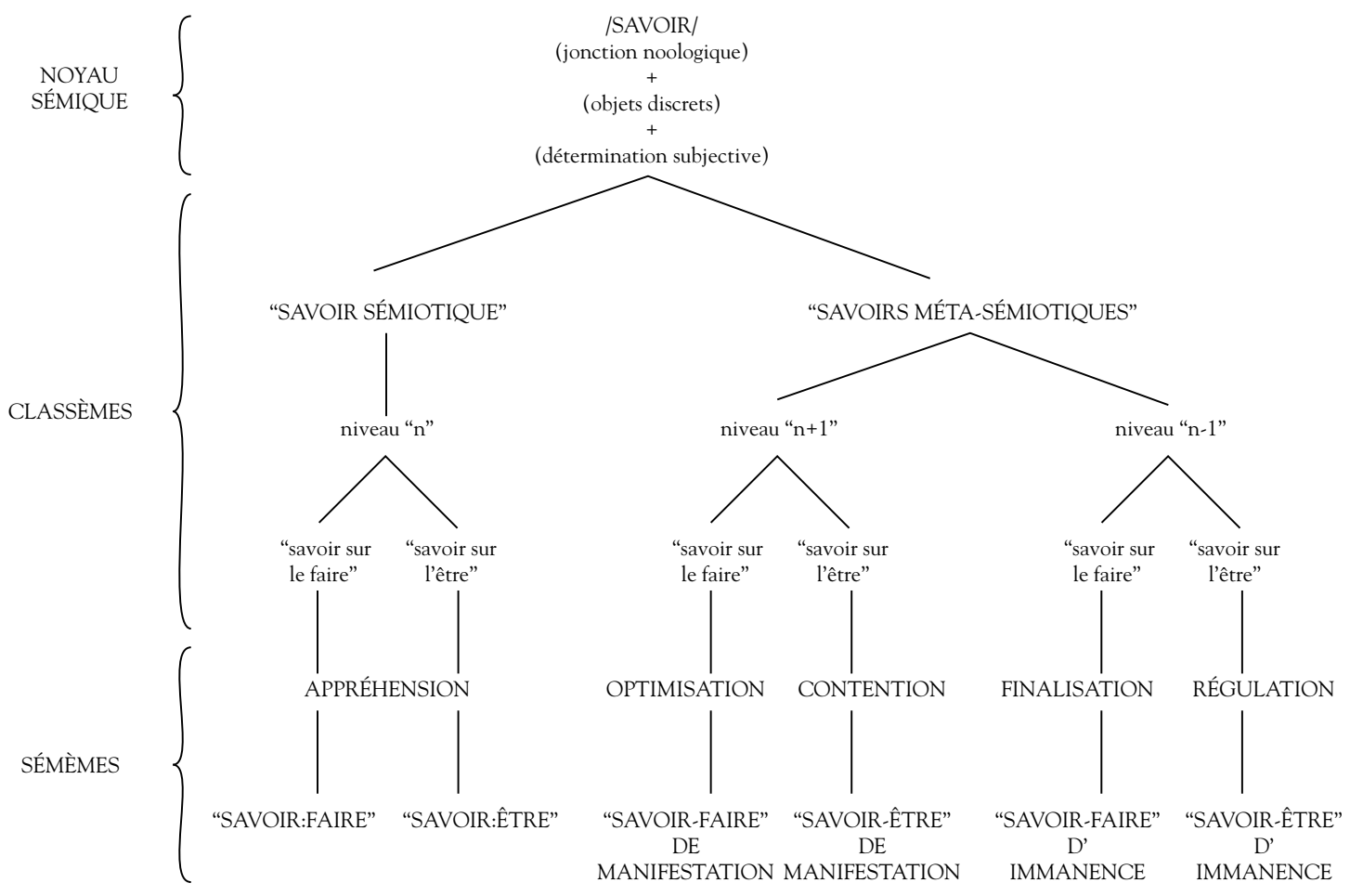

(Fontanille, 1987, p. 34)

Um último conteúdo teórico que gostaríamos de recuperar de Le savoir partagé - e que fomenta a discussão a ser apresentada no capítulo 3 desta dissertação - está contido no item II.5 do texto de Fontanille, que traz o título "Savoir et croire", em que o semioticista põe as modalidades SABER e CRER em relação e discorre sobre a natureza de seu liame.

Fontanille introduz a questão retomando o texto de Greimas "Le savoir et le croire: un seul univers cognitif" (1983): "Em Du Sens II, A. J. Greimas sustenta a ideia de que o saber e o crer fazem parte do mesmo universo cognitivo, e até mesmo que o crer precede e engloba o saber" (Fontanille, 1987, p. 54). Para Fontanille, duas restrições de Greimas relativas à distinção entre SABER e CRER são incontornáveis: a diferença de generalidade de uma parte e a antecedência sintática do crer de outra.

Aqui, abrimos um parêntese. Ao afirmar que Greimas defende que o CRER precede o SABER, Fontanille faz referência pontual ao conteúdo do item "2.2 Le croire précède le savoir" do texto contido em Du Sens II. Ao longo desse item, Greimas argumenta pela precedência do CRER em um local bem delimitado do percurso gerativo de sentido: ele toma como pano de fundo para sua reflexão 
uma situação intersubjetiva de comunicação que, para existir, pressupõe um "eu creio que" por parte do destinador e, consequentemente, um "é preciso que você creia que eu creio que" relativo ao destinatário.

Uma vez instaurado por esse pacto fiduciário mínimo, o contrato, que Greimas denomina também como "prelúdio à comunicação" (1983, p. 123) e que, por si só, já é um "fazer-crer" (aqui, de caráter primordial à comunicação), o destinador então pode pôr em funcionamento inúmeros procedimentos de manipulação para levar o destinatário a crer no que ele diz, uma ação essencialmente epistêmica. Nas palavras de Greimas:

(...) toda comunicação humana, toda transação, mesmo se ela não é verbal, repousa sobre o mínimo de confiança mútua, que engaja os protagonistas naquilo que chamamos de contrato fiduciário. Que esse contrato seja anterior a qualquer comunicação ou que ele se instaure a partir do primeiro contato pouco importa: isso lembra um pouco a história do ovo e da galinha. Praticamente, o analista tem necessidade de uma situação-limite e de um gesto epistêmico que abre a comunicação. Que se trate de um eu penso seguro de si ou de um eu sei hesitante, que eles sejam proferidos em voz alta ou somente implícitos, o desencadeamento que eles provocam pode ser chamado de proposição de contrato. (...) Ou seja, em outros termos, toda proposição formulada pelo enunciador repousa sobre uma base epistêmica que leva da afirmação à dúvida e da refutação à admissão (...). Esse ato epistêmico, porém, que serve de prelúdio à comunicação, não é uma simples afirmação de si, mas um avanço, uma solicitação de consenso, de um contrato, aos quais o enunciatário dará sequência por uma aceitação ou recusa. Entre essas duas instâncias e essas duas tomadas de posição se encontra organizado um espaço cognitivo da persuasão e da interpretação que corresponde, no plano das estruturas semionarrativas, aos vastos maquinários da manipulação e da sanção. (1983, p. 122 - 123).

Em suma, para que exista o contrato, caracterizado essencialmente por seu aspecto fiduciário, é preciso que haja o mínimo de crença. E, por esse motivo, Greimas argumenta, para esse local específico do esquema narrativo global, pela precedência sintática do CRER.

Porém, e isso justifica nosso parêntese, nesse mesmo capítulo de Du Sens II, encontramos também o item 2.1 intitulado "Le savoir précède le croire". 
Nele, Greimas propõe captar a especificidade do fenômeno "crer" no interior da comunicação intersubjetiva substituindo-se as instâncias "neutras" de emissor e receptor respectivamente pelas noções de um fazer-crer e um crer, um ato essencialmente epistêmico resultante de uma persuasão. Para ilustrar sua reflexão, Greimas elege como um sinônimo para persuasão o verbo "convaincre”, retirado da língua natural francês, onde encontra a seguinte definição dicionarizada: "Conduzir alguém a reconhecer a verdade de uma proposição" (Greimas, 1983, p. 117).

A partir daí, Greimas concebe o ato epistêmico, situado na dimensão cognitiva do discurso, como uma transformação, uma passagem "daquilo que é negado àquilo que é admitido; daquilo de que duvidamos àquilo que aceitamos, etc." (Greimas, 1983, p. 118) e afirma que o fazer interpretativo pode ser reduzido, em última instância, "a uma operação de reconhecimento (da verdade). Porém, o re-conhecimento, contrariamente ao conhecimento, é uma operação de comparação daquilo que é proposto (...) com aquilo que já se sabe/ crê. O reconhecimento, enquanto comparação, comporta necessariamente uma identificação" (Greimas, 1983, p. 119). O ato epistêmico, assim, opera por meio de um controle de adequação, uma adequação ao nosso próprio universo cognitivo, uma "adequação do novo e do desconhecido ao velho e conhecido" (Greimas, 1983, p. 119), um processo de comparação do que é proposto com o que é sabido. É nesse sentido, e por esse viés, que identificamos e propomos entender, no texto de Greimas, a defesa de uma precedência do SABER em relação ao CRER.

Dessa maneira, fica expresso que, embora Fontanille retome e destaque o fato de que Greimas defende a precedência do CRER em relação ao SABER em Du Sens II, o que encontramos no texto do semioticista lituano é a coexistência das duas proposições: o SABER precede o CRER e o CRER precede o SABER. Cada uma delas, porém, parece se aplicar a momentos distintos do percurso gerativo de sentido. Enquanto a precedência do CRER em relação ao SABER estaria legitimada pelo fato de que, para que qualquer contrato comunicacional seja instaurado entre destinador e destinatário, é exigida a existência de uma crença mínima, a precedência do SABER em relação ao CRER se coloca no interior do fazer interpretativo do destinatário, que procede a operações cognitivas de comparação e adequação do que é proposto com o que é sabido, sob a lógica do re-conhecimento e da identificação, para conhecer algo no mundo.

Se pensarmos, porém, na ordem canônica do percurso gerativo de sentido ou do esquema narrativo global, a instauração do contrato antecede, forçosamente, 
o fazer interpretativo do sujeito destinatário. E, por isso, a precedência do CRER poderia ser entendida, efetivamente, como uma precedência primeira nos fenômenos de comunicação humana. Daí a reiteração, por parte de Fontanille, da antecedência sintática do CRER.

Voltando a Le savoir partagé, podemos verificar Fontanille considerar, de fato, que "nenhum saber pode ser enunciado sem ser antecipadamente modalizado por um julgamento epistêmico (de certeza, de improbabilidade, etc.), que o transforma ipso facto, em crer" (Fontanille, 1987, p. 55) e defender, assim, que toda comunicação e, portanto, até mesmo toda troca de saberes, pressupõe uma confiança e uma suposição, ou seja, como já vimos, um "eu creio que" e, correlativamente, um "é preciso que você creia que eu creio que". A esse respeito, Fontanille afirma que (e aqui ele toca na outra restrição greimasiana incontornável em relação a essas duas modalidades, a sua diferença de generalidade), se considerarmos apenas esses fatos, "a diferença entre crer e saber lembra um pouco aquela que a gramática distribucional chama de "sistema da marca" que pode ser observada, por exemplo, na categoria semântica do gênero (feminino e masculino) nas línguas naturais:

(...) em vez de se manifestar sob a forma de dois traços distintivos em relação ao todo, uma categoria semântica ou morfológica, como o gênero, se realiza pela oposição "presença/ausência” de um traço de expressão. Aquilo que caracteriza no plano semântico o sistema da marca é que os dois constituintes da categoria não têm o mesmo estatuto e nem a mesma distribuição: um dos dois, o termo não marcado, serve de termo genérico, de termo neutro, etc. (Fontanille, 1987, p. 55)

O autor argumenta que, portanto, em relação ao CRER e ao SABER, poderíamos fazer a mesma observação: "o saber seria o termo não marcado, e o crer o termo marcado" e, nesse sentido, poderíamos facilmente explicar, visto que um termo "comporta uma carga semântica suplementar, que eles não fazem parte do mesmo nível do percurso gerativo de sentido" (Fontanille, 1987, p. 55). Para Fontanille, no desenrolar desse percurso, os saberes encontrariam inevitavelmente os julgamentos epistêmicos, que os converteriam em crenças. Relacionando essa noção com a sua distinção precedente entre saberes semióticos, em nível "n", e saberes meta-semióticos, em nível "n+1" ou "n-1", Fontanille afirma que: "De 
fato, toda troca de saber, situada em um nível narrativo 'n', é sobredeterminada, em um nível 'n+1', por uma relação fiduciária” (1987, p. 55). E ressalta, além disso, que tal sobredeterminação não é exclusiva à troca de saberes: não somos capazes de fugir ou nos abster dessa relação fiduciária para garantir a troca de valores, quaisquer que sejam eles.

Nesse contexto, ele analisa o caso extremo de troca em que os valores são crenças, como no catecismo, e indica que essa troca será também sobredeterminada pela relação fiduciária, ou seja, aqui o crer pressupõe o crer, e estão preservados os níveis " $n$ ”, ocupado por uma troca de valores, e um nível "n+1", ocupado por uma relação fiduciária. Finalmente, o autor postula que o conteúdo semântico que está presente no CRER (termo marcado) e ausente no SABER (termo não marcado) é o traço /tímico/: no CRER ele aparece combinado ao traço /cognitivo/, e essa combinação determina, assim, sua menor generalidade.

Ficam, dessa maneira, apresentados e, de certa forma, resenhados, os quatro textos recolhidos à teoria semiótica da Escola de Paris por apresentarem tratamento eminente sobre as modalidades investigadas nesta dissertação de mestrado: "Le savoir et le croire: un seul univers cognitif", capítulo de Du Sens II (1983), de Algirdas Julien Greimas, "Reconnaissance de l'espace fiduciaire", capítulo de Raison et poétique du sens (1988), de Claude Zilberberg, "Un point de vue sur 'croire' et 'savoir' - Les deux systèmes de l'adéquation cognitive” (1982), artigo de Jacques Fontanille, e a parte I de Le savoir partagé - Sémiotique et théorie de la connaissance chez Marcel Proust (1987), obra também de autoria de Jacques Fontanille.

\section{$1.4 \mathrm{O}$ horizonte de retrospecção teórico}

Sob o contexto das observações acima, podemos traçar um brevíssimo histórico da questão do CRER e do SABER para além (e aquém, cronologicamente) dos quatro textos que formam a base teórica de nossa reflexão semiótica apresentados nos itens precedentes. Propor uma revisão da literatura relativa ao tema CRER e SABER é uma tarefa de ampla envergadura que não cabe nas pretensões de fôlego mais curto que o presente trabalho sustenta. Porém, interessa-nos aqui ao menos pontuar, em um eixo cronológico, alguns autores que instituíram ao CRER e o SABER como um tema, questão ou "problema filosófico". 
Ressaltamos que, frente ao caráter multidisciplinar desse objeto de investigação científica, é a visada semiótica que norteia nossa análise e nos mune de instrumentos, reflexões e modelos teóricos para a abordagem das modalidades CRER e SABER e também das categorias modais aí aderidas, a dúvida e a certeza. É importante atentar para o fato de que a semiótica, enquanto ciência autônoma, constrói seu objeto para análise e, portanto, o CRER e o SABER sobre o qual nos debruçamos aqui é distinto daquele construído em outras ciências, como na filosofia, por exemplo. Por outro lado, lembramos que, em ciência, as ideias não surgem no vácuo.

Justamente por isso, os textos que constroem o nosso objeto-problema tratam de um tema milenarmente discutido em filosofia e também já amplamente debatido em outras áreas da linguística que não a semiótica, como a pragmática: a questão da definição, descrição, distinção e funcionamento, entre outros aspectos, do CRER e do SABER (em si e em relação). A partir desse cenário, colocamos a questão: qual é o horizonte de retrospecção teórico que a semiótica pode traçar para si?

Em 1983, Herman Parret organiza um volume intitulado De la croyance Approches épistémologiques et sémiotiques, que reúne 21 artigos que se valem tanto de abordagens epistemológicas como semióticas do tema. Sobre a questão, Parret afirma:

\begin{abstract}
Olhando-se para o landscape semiótico, tem-se a falsa impressão de que a semiótica da crença não tem mais do que dez anos. A definição de crença como "a adesão do sujeito ao enunciado de estado (...), como um ato cognitivo sobredeterminado pela categoria modal da certeza" ${ }^{14}$ (Greimas-Courtés, 1982 [1979], p. 24) manifesta categorias wittgensteinianas, e mostra que a semiótica não é uma disciplina idiossincrática escrita sobre uma tabula rasa. $(1983$, p. 4 - 5)
\end{abstract}

Mais adiante, Jean Petitot, em seu artigo que integra o volume, "Choix et croyance: vers une logique de l'idéal”, com vistas a compreender melhor a dimensão histórica aderida ao tema, aponta Crítica do Julgamento (1790), de Kant,

14 Na edição do Dicionário de Semiótica (Greimas e Courtés, 2008) utilizada por nós, e que consta em nossas referências bibliográficas, o trecho citado por Parret é encontrado na pág. 107. 
como o mais importante texto da "pré-história" do problema semiótico do CRER. De acordo com Petitot (1983, p. 243), nenhuma semiótica do CRER e do SABER pode ser instituída sem estabelecer uma relação essencial com a sistemática de Kant: a oposição SABER vs. CRER simula as oposições kantianas, como conceito vs. ideia e determinação vs. reflexão.

Para o autor, um estágio interventor entre Kant e as teorias contemporâneas sobre o CRER é a crítica de Husserl ao objetivismo da ciência positivista. Petitot relembra o fato de que, de acordo com Husserl, a ciência não é independente da crença e esse é o motivo pelo qual o conhecimento não pode se opor radicalmente à crença.

Os paradigmas evocados desse modo por Petitot (a saber: Kant, Husserl e teoria semiótica contemporânea) não nos deixam esquecer as bases fenomenológicas da semiótica greimasiana, sobretudo a herança de MerleauPonty, das quais a semiótica se reaproxima ao conceber as ferramentas tensivas: exatamente aquelas que permitem a abordagem dos conteúdos sensíveis tímicos, próprios do CRER) no interior do discurso. Retomaremos esse debate, que tenta refletir sobre a pertinência da recuperação de conceitos da fenomenologia e tese fenomenológica sobre a linguagem para a melhor compreensão da etapa pressuposta pela modalização do sujeito segundo um CRER ou um SABER, a sua percepção do fenômeno, no capítulo 4 desta dissertação, intitulado "Modalização e percepção (unidade pressuponente e pressuposta)".

Ainda em De la croyance (Parret, 1983), Paul Ricoeur, em seu artigo "La problématique de la croyance: opinion, assentiment, foi", amplia o horizonte de retrospecção como proposto por Petitot e aponta a contribuição do pensamento pré-kantiano para a definição do que debateriam teorias ulteriores quando se debruçassem sobre a questão do CRER e do SABER:

Para introduzir uma pesquisa interdisciplinar sobre o crer e o saber, é importante manter presente no espírito a diversidade de contextos filosóficos em que esses dois termos se revestiram de suas significações de base na tradição pré-kantiana. Essa revisão histórica tem a função crítica de alertar contra a ilusão de binarismo elementar que a dupla crer e saber parece apresentar; por outro lado, ela dá a medida das dificuldades encontradas por todas as tentativas de solução, de uma maneira ou de outra, do kantismo para ordenar a dupla crer e saber. (Ricoeur, 1983, p. 292) 
Nesse sentido, ele afirma que três contextos anteriores ao grande tournant da Crítica kantiana merecem ser reativados, ressaltando que o kantismo não se limita a eles e nem os abole, mas antes os conserva ao reinterpretá-los. A primeira das heranças pré-kantianas inscritas no tratamento do CRER e do SABER, para Ricoeur, é a problemática platônica da doxa, que toma a crença como opinião. Ela traz consigo dois caracteres: o epistemológico, segundo o qual "a opinião está abaixo em uma escala de saber na qual o nível superior é a episteme, a ciência"; e o ontológico, que, para conservar uma exigência parmediana, postula que "aquilo que é e aquilo que é pensado são a mesma coisa. Isso resulta no fato de que a oposição entre ser e parecer recupera aquela entre ciência e opinião" (Ricoeur, 1983, p. 292).

A segunda herança pré-kantiana é a problemática cartesiana do consentimento, que compreende a crença como julgamento e tem origem no estoicismo. Segundo o autor, essa problemática provém de uma distribuição totalmente distinta de noções, que ele define como uma "verdadeira análise psicológica" da operação em que consiste "a captura (catalepsis) ou apreensão de coisas, que se decompõe em dois termos, um é 'recebido': imagem, a representação (phantasia); e o outro é uma verdadeira ação: o consentimento (sunkatathesis)" (Ricoeur, 1983, p. 293). Em seguida, Ricoeur destaca:

\begin{abstract}
A noção estoica de consentimento comanda a filosofia cartesiana do julgamento, que se encontra curiosamente no cruzamento entre a tradição platônica sobre as relações entre o saber e a opinião e a tradição estoica sobre as relações entre o consentimento e a representação. Essa situação complexa explica sem dúvida por que Descartes não chama a "crença" de consentimento e continua, em bom platonismo, a opor a crença, tomada no sentido de "opinião", à ciência verdadeira. (1983, p. 293)
\end{abstract}

$\mathrm{O}$ autor ressalta ainda que, em $T^{e}$ Méditation Métaphysique, Descartes decompõe o julgamento em vontade e entendimento. Assim, a crença apresenta dois traços: ao mesmo tempo em que exprime a espontaneidade do pensamento como ato, ela marca a adesão do espírito a seus conteúdos pensados. Ricoeur chama atenção para o fato de que essa segunda herança ou problemática não 
abala a primeira, pois, aqui, a opinião, que se torna preconceito, permanece distinta da verdade.

Finalmente, para o autor, a terceira herança pré-kantiana consiste na problemática cristã da fé, que tem origem no Novo Testamento. Ricoeur a introduz afirmando:

No seu sentido no Novo Testamento, a fé responde à questão da salvação, vinda do fundo das religiões, e exprime a experiência central da comunidade que se confessa (fé na Ressurreição de Cristo). Essa problemática se distingue da primeira visto que o contrário da fé não é a ciência, mas o pecado. (...) A problemática da fé igualmente se distingue da do consentimento, visto que a semelhança entre o engajamento pessoal da fé e a adesão do julgamento permanece abstrata, levando-se em consideração a diferença entre as temáticas completas: a distância que separa "crer em..." e "crer que..." deve ser preservada apesar das homologações apressadas entre opinião, consentimento e fé no plano subjetivo. (1983, p. 293 - 294)

Diante de tais problemáticas heterogêneas que integram a herança prékantiana da filosofia, Ricoeur propõe em seu artigo, então, analisar o que considera como três tentativas de integração que visam colocar essas heranças em perspectiva: a filosofia kantiana, a fenomenologia husserliana e a semiótica textual. Para o autor, cada uma das tentativas "parte de pressuposições que podem ser empregadas com títulos diversos sob a sigla da "redução" (Ricoeur, 1983, p. 294): a filosofia kantiana realiza a redução ao fenômeno, a fenomenologia husserliana, a redução ao vivido, e a semiótica textual, a redução ao discurso enunciado.

Cada uma delas, para Ricoeur, realiza uma redistribuição das categorias da crença e "cada uma também paga um preço talvez cada vez mais custoso pelo sucesso de sua tentativa de pôr em ordem a crença-opinião, a crençaconsentimento e a crença-fé" (Ricoeur, 1983, p. 294). Sob o ponto de vista do autor, o principal preço pago pela redução ao discurso enunciado, e seu corolário dentro da teoria semiótica, a ilusão referencial, seria a perda de qualquer alteridade em relação à linguagem. Ao postular a imanência da linguagem, a semiótica substitui o problema da verdade pelo do verossímel. E seria, portanto, 
por meio de um empréstimo "disfarçado" das velhas categorias da epistemologia e da ontologia platônicas que o saber-ser, completamente imanentizado no discurso enunciado, viria ao socorro de um crer-verdadeiro para estruturar, então, a ilusão referencial, a instância do verossimilhante.

Por meio desse brevíssimo histórico, buscamos reunir alguns pontos de determinadas teorias que contribuíram historicamente para que a questão do CRER o do SABER se constitua como um objeto de pesquisa para a semiótica hoje. Se, ulteriormente às teorias desenvolvidas por Greimas, Fontanille e Zilberberg, apontamos alguns pensadores que se debruçaram sobre nosso tema de pesquisa, formando, desse modo, um horizonte possível de retrospecção para a semiótica enquanto ciência, muitos outros semioticistas, já sob o paradigma greimasiano, também colaboraram por meio de suas reflexões para a semiotização das noções do CRER e do SABER para além dos quatro textos que compõem a fundamentação teórica desta dissertação.

Entre inúmeras outras, podemos citar, por exemplo, as contribuições de Coquet, Landowski, Geninasca, Parret, Pottier, etc. Destacamos que o último, Bernard Pottier, em "Le croire dans une perspective sémio-linguistique dynamique" (1983), faz a mais importante crítica ao quadrado epistêmico tal como apresentado por Greimas e Courtés no Dicionário de Semiótica (2007, p. 172). Pottier argumenta que "não existe contrariedade entre 'certeza' e "improbabilidade" (Pottier, 1983, p. 272) e defende que o termo "excluído" deveria estar presente, sugerindo, portanto, em Théorie et analyse en linguistique (1987), que a modalidade epistêmica seja representada pelo seguinte quadrado:

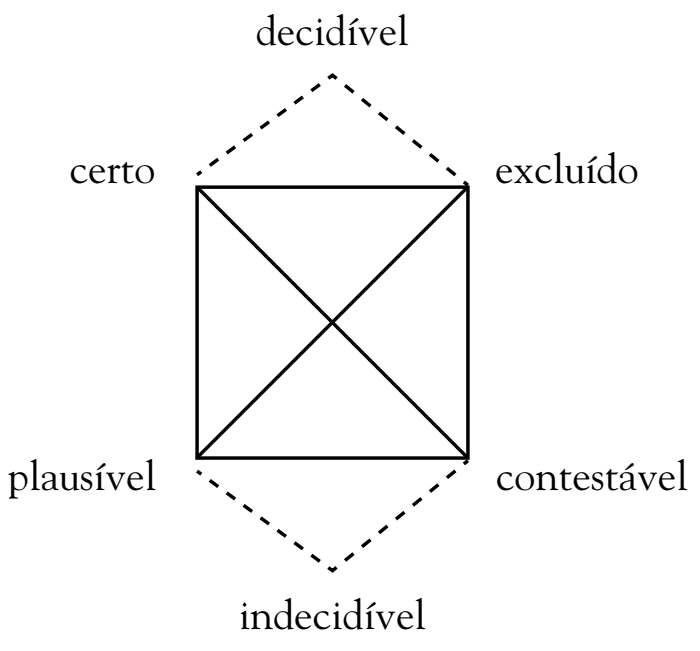

(Pottier, 1987, p. 208) 
Se, como já estipulamos, em relação ao histórico debate interdisciplinar concernente a nosso tema de pesquisa, tomamos para análise o objeto CRER e SABEr tal como ele é definido e descrito pela teoria semiótica, diante do rico conjunto de reflexões sobre essas modalidades desenvolvido já no âmbito da semiótica da Escola de Paris, buscaremos nos ater aos conteúdos teóricos convocados por nossos objetos de análise, que começam a ser apresentados a seguir. 


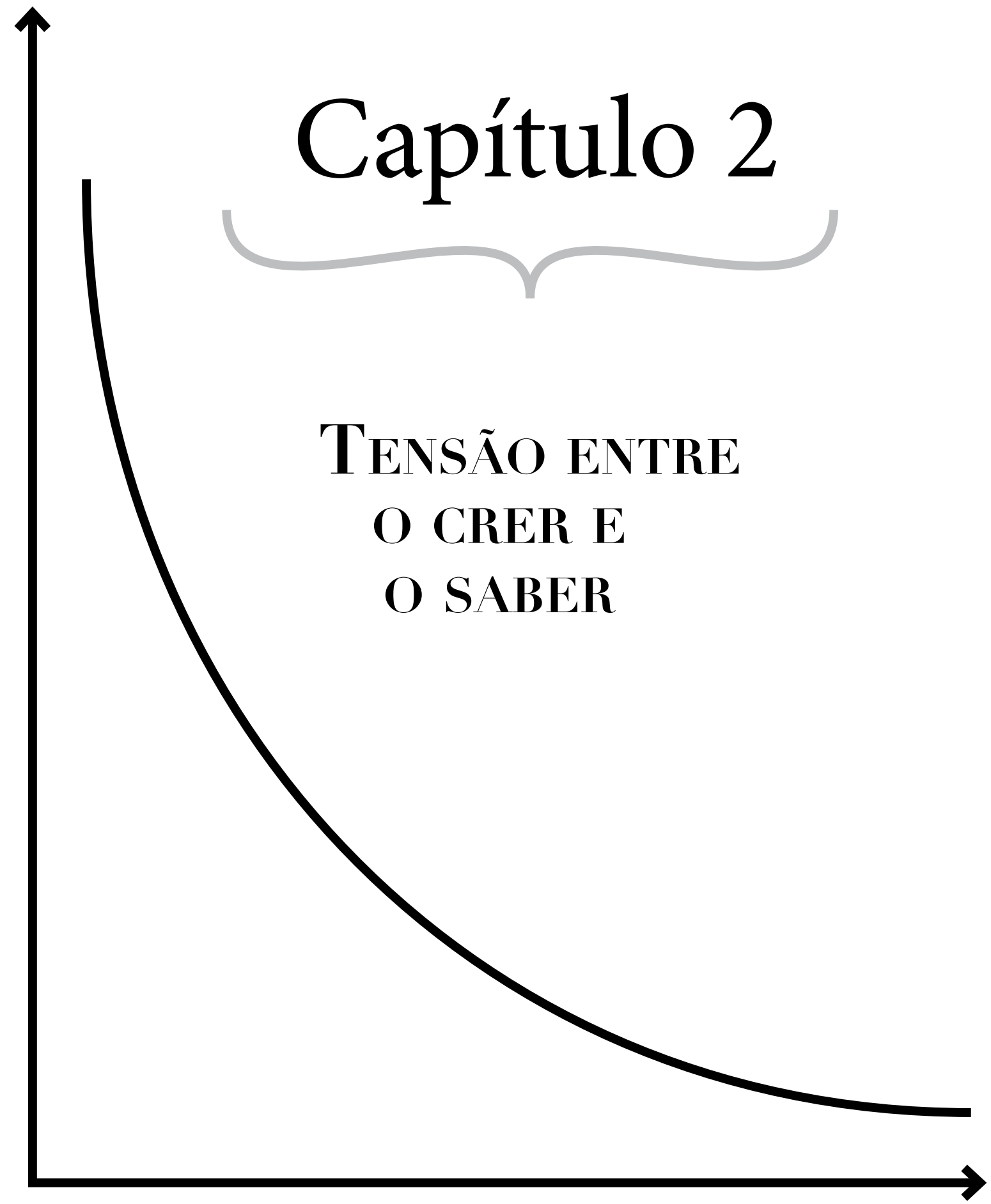




\subsection{Os termos em relação - A relação como produtora de diferenças}

A conceitualização semiótica relativa ao CRER e ao SABER aponta para um consenso teórico que aloca ambas as modalidades no âmbito do universo cognitivo. Encontramos também certa conformidade em relação ao elemento responsável pela diferenciação semiótica fundamental desses dois termos: o CRER, portador do traço /tímico/, convocaria para o interior da lógica cognitiva a dimensão da timia. É o que defende, por exemplo, Fontanille (1987, p. 56) no seguinte trecho: "Qual é portanto o conteúdo semântico que estaria presente no crer e ausente no saber? Propomos, como já fizemos antes ${ }^{15}$, reconhecer no semema /crer/ a combinação de um traço /cognitivo/ com um traço /tímico/".

Por ter sua consistência semiótica desse modo definida, ou seja, pela presença de uma carga semântica suplementar de caráter tímico, o CRER caracteriza modalmente o sujeito fiduciário que, como descrito por Zilberberg (2006, p. 159 , é aquele que acredita no objeto-valor e no valor do valor e, de acordo com Fontanille (1982, p. 20), procede por meio de operações cognitivas de adesão, e não apenas de afirmação, relativas a seus objetos. Se pensarmos em termos dos movimentos modais cognitivos contidos na argumentação - e Fontanille o faz em "Un point de vue sur 'croire' et 'savoir" (1982) ao se voltar a quatro dos Diálogos de Platão para dali extrair operações discursivas que delimitam e caracterizam dois tipos de sistemas de adequação cognitiva - verificaremos que a adesão, que reivindica tanto a dimensão intelectual (cognitiva) como a sentimental (tímica), ocorre como resultado de um procedimento intersubjetivo de persuasão bem-sucedido.

Em formulação semiótica, do traço /tímico/ aderido ao CRER decorre, para Fontanille, o fato de que, no sistema de adequação do CRER, o sujeito opera por meio de operações fiduciárias "denominadas por Sócrates como "persuasão", e, no sistema do SABER, por meio de operações científicas "denominadas por Sócrates como "convicção" (1982, p. 21). A retórica concebe a persuasão como procedimento argumentativo pelo qual o orador busca especificamente a adesão de sua audiência, ou seja, busca fazê-la crer no que ele diz. Guardadas as devidas especificidades conceituais de cada disciplina, e a não correspondência

15 Nesse ponto do texto, Fontanille insere uma nota que remete a seu artigo:

"Pour une topique narrative anthropomorphe", Actes Sémiotiques - Documents, VII, 57, 1985. 
de significado de um mesmo termo empregado por duas teorias distintas, a noção de persuasão encontrada no âmbito da semiótica é próxima: a persuasão aparece na instância da manipulação, na forma de um fazer persuasivo da parte do destinador, que pode proceder tanto por meio de uma manipulação fiduciária (que visa ao fazer-CRER) quanto de uma manipulação do tipo factitiva (que conduz ao fazer-fazer).

A partir dessa caracterização, o fazer-SABER, em semiótica, seria um dos resultados da manipulação factitiva que, de forma geral, faz-fazer? O SABER poderia resultar de um tipo de persuasão? De fato, se recorrermos à definição dicionarizada do termo, encontramos para "persuadir" uma definição que nos remete somente ao fazer acreditar:

Persuadir: $v$. (sXV cf. FichlVPM) 1.t.d., bit. e pron. levar ou convencer (alguém ou a si mesmo) a acreditar ou aceitar, convencer(-se) <tentou p. o jovem (a adotar uma crença) > <persuadiu o amigo (a ocupar o cargo) > <persuadiu-se da veracidade daquelas palavras>. (Houaiss, 2008, p. 2197, grifos nossos)

Aqui, colocamos a questão: seria possível, então, por meio de uma relação intersubjetiva de comunicação, fazer-SABER? Se recolhermos reflexões de Fontanille ao longo de Le savoir partagé (1987), constatamos que o autor tende a responder essa indagação com uma negativa:

Enquanto objeto de valor, o "saber" propriamente dito é um objeto conquistado e construído por um sujeito operador autônomo, que supõe obrigatoriamente o fazer cognitivo e exclui a intervenção de um destinador exterior para garantir o saber: o "répondant" 16 - para retomar uma expressão de M. de Certeau ${ }^{17}$ - só pode ser sincrético e interno. Em contrapartida, o crer não é conquistado ou construído, mas adquirido: de qualquer maneira, mesmo se há construção ou conquista parcial de um saber, o crer começa quando a construção ou conquista cessam, ou seja, onde intervém o destinador que atribui e garante ao mesmo tempo a crença. Se, no caso do saber propriamente dito, a relação típica é aquela entre o objeto de valor e o sujeito do fazer, no caso do crer, a relação

16 Algo como "fiador", aquele que garante a consistência do objeto cognitivo.

17 Certeau, M. de. "Le croyable". In: Parret, H. e Ruprecht, H. G. (org.) Exigences et perspectives de la sémiotique. Recueil d'hommages à A. J. Greimas, Amsterdã, Benjamins, 1985. 
típica é aquela que une o destinador e o destinatário. (Fontanille, 1987 , p. $56-57)$

Tal caracterização do CRER como a arena do intersubjetivo e do mediado, que traz como sua contraparte o SABER como construção individual do objeto, com o qual se trava uma ligação imediata, é encontrada também em Fontanille (1982, p. 11), onde temos a definição da relação dominante no sintagma intersubjetivo como sendo S2 - S1 (ligação às pessoas) para o universo do CRER, e S2 - Obj (ligação às ideias) para o universo do SABER; e ainda em Fontanille (2007, p. 227), onde o semioticista defende que a diferenciação entre o CRER e o SABER pode ser introduzida "formulando-se a questão do modo de relacionamento e de valorização do objeto cognitivo".

Assim, "o saber baseia-se na simples relação entre objetos cognitivos" e, se "o objeto cognitivo é relacionado a outros objetos cognitivos com o único propósito de avaliar sua diferença”, estamos no campo do SABER, enquanto que, se o objeto se relaciona "ao mesmo tempo com outros objetos e outros sujeitos (entre outros, o próprio observador)", estamos no âmbito do CRER, que guarda como base "uma relação triangular, tendo a instância de discurso tomado uma posição entre os dois objetos cognitivos" (Fontanille, 2007, p. 227).

Outra especificidade que pode ser destacada em relação à descrição e caracterização formal do CRER diz respeito a seu estatuto dentro da teoria semiótica da Escola de Paris, como aponta Zilberberg (2006, p. 160): "Mas seria o crer uma modalidade? Seu estatuto, na teoria semiótica, parece incerto: ele não figura no artigo 'Modalidade' ${ }^{18} \mathrm{e}$, no entanto, tem direito a um verbete próprio ${ }^{19}$ ". O CRER, para Zilberberg, guarda algumas semelhanças e diferenças quando comparado às demais modalidades formalmente definidas dentro do paradigma da semiótica padrão:

O crer compartilha com as demais modalidades a capacidade de reger um outro enunciado, mas diferencia-se delas pelo fato de reger um outro enunciado modal: afinal, o dever e o querer não pressupõem um crer, ou seja, uma junção com o valor do valor?

18 Greimas, A. J. \& Courtés, J. [1983] Dicionário de Semiótica. Tradução Alceu Dias Lima et al. São Paulo, Cultrix , p. 282 - 284.

19 Greimas, A. J. \& Courtés, J. [1983] Dicionário de Semiótica. Tradução Alceu Dias Lima et al. São Paulo, Cultrix , p. 126. 
Para levar a bom termo um empreendimento, o senso comum não recomenda "acreditar nele"? (Zilberberg, 2006, p. 160)

O CRER, enquanto dispositivo semiótico capaz de modalizar o já modalizado, como nos exemplos apontados por Zilberberg de CRER-DEVER e CRER-QUERER, convoca a teoria a novas reflexões sobre sua definição e seu funcionamento e demanda uma descrição que parece ir além daquela convencionalmente empregada para as modalidades. Uma vez que o traço/tímico/é apontado como uma carga semântica suplementar do termo CRER (/tímico/ e /cognitivo/) em relação ao SABER (apenas /cognitivo/), vislumbramos aqui outra carga suplementar aderida ao CRER, desta vez relativa ao poder de regência de enunciados modais.

Lembramos que tal capacidade engendra o CRER-SABER, arranjo modal a ser mais detidamente analisado no capítulo 3 desta dissertação. Tal arranjo modal abre o precedente para que mesmo a ciência possa ser analisada enquanto espaço para crenças e para a aposta, como definida semioticamente por Fontanille (1982, p. 29). De acordo com Greimas e Courtés (2008, p. 107 - 108), o CRER figura como instância fundamental do discurso científico, e não apenas como base do discurso religioso e da fé, sobretudo por ser incluído no eixo da comunicação, "no quadro do fazer interpretativo enquanto ponto de chegada e sanção final deste". Tal posicionamento canônico do CRER no esquema narrativo, como elemento central do "prelúdio da comunicação", para retomar um termo de Greimas (1983, p. 123), e como chave epistêmica que fecha a narrativa via sanção, mostra-nos tal modalidade como dispositivo semiótico constitutivo das portas de entrada e de saída que contêm, no espaço entre si, todo o labirinto possível da comunicação humana.

Ressaltamos ainda que, a partir do arranjo CRER-SABER, é possível pensar em relações de hierarquização e precedência entre os termos, conceitos que buscaremos discutir mais adiante nesta dissertação, ao longo do capítulo 3. Por ora, afastamo-nos momentaneamente da discussão concernente à capacidade suplementar do CRER em reger enunciados modais e nos voltamos para a análise do tipo de relação que se pode conceber entre os termos CRER e SABER enquanto modalidades no mesmo nível do percurso gerativo de sentido. 


\subsection{Duas hipóteses em jogo segundo Lopes e Beividas $(2009)$}

Se a distinção entre CRER e SABER funda-se primordialmente, como vimos, na presença do traço /tímico/ naquele termo, e daí decorrem algumas consequências teóricas que acabamos de elencar sucintamente, o que se pode dizer quanto à natureza do liame entre as duas modalidades? Sobre seu modo de relacionamento, Zilberberg (2006, p. 160) especula: "Seriam o crer e o saber, um em relação ao outro, variantes ou invariantes?"; e, logo, aponta que "A tendência atual em semiótica seria considerá-los sobretudo como variantes".

Essa tendência, ainda de acordo com Zilberberg, pode ser identificada em Fontanille (1982) e sua distinção de dois sistemas, o sistema do CRER, baseado na "manipulação" e no "dever-ser", e o sistema do SABER, baseado na "ação" e no "poder-ser", que pressupõem um só sujeito cognitivo e funcionam sob a lógica da alternância: quando um sistema está atualizado, o outro é virtualizado; e também em Greimas que, em "Le savoir et le croire: un seul univers cognitif", ao afirmar que "a sanção deve ser interpretada como uma adesão do enunciado proposto à parcela formalmente correspondente no universo cognitivo" (1983, p. 126), aponta ser no interior desse lugar formal que a sanção escolhe a variante de sua estrutura, que pode ser fiduciária ou lógica.

De nossa parte, ressaltamos ainda outra elaboração greimasiana, encontrada no mesmo texto de 1983, que, se por um lado, dá conta da relação entre CRER e SABER como variantes, em conformidade com o aspecto destacado por Zilberberg (2006, p. 160), comporta também a ligação de caráter paradoxal que parece unir esses dois termos. Greimas aponta para a existência de um processo de polarização categórica, que cria tensão entre os termos, ao lado de sua variante regulatória e limitante, a distensão que pode levar as modalidades a se confundirem. 
Sugerimos aqui as seguintes representações gráficas para esses processos complementares:

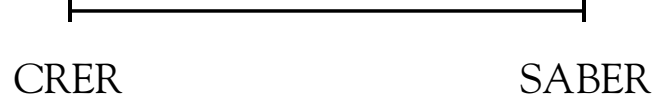

- Cisão

- Polaridade

- Alta tensão

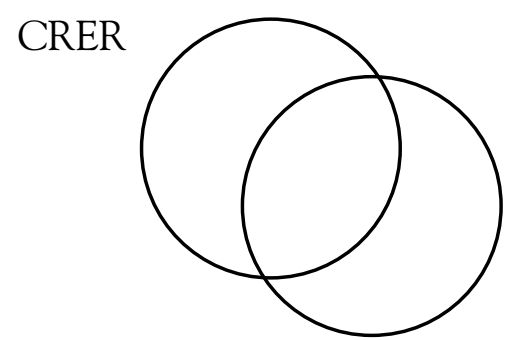

SABER

- Fusão

- Composição

- Baixa tensão (distensão)

Essa formulação greimasiana é um dos motes para o artigo "Argumentação e persuasão: tensão entre CRER e SABER em 'Famigerado', de Guimarães Rosa”, de Lopes e Beividas (2009). Segundo os autores, Greimas (1983, p. 115 - 133) sugere que:

(...) entre o saber e o crer - que defende como um "mesmo universo cognitivo" em texto memorável do livro Du Sens II -, há um jogo "elástico" de força, de um lado, para uma tensão de polarização categórica e, de outro, para uma distensão que pode fazê-los confundirem-se (...). (Lopes e Beividas, 2009, p. 446)

Nesse artigo, então, Lopes e Beividas buscam testar, ilustrativamente em um conto de Rosa, "até que ponto se pode manter como recorrente esta hipótese, simplificada ao mínimo necessário: o crer tensiona e o saber distensiona. Mais e mais crer, maior tensão; mais e mais saber, maior distensão, estando nas valências intermediárias e 'elásticas' desses vetores a nossa situação geral de homens sem garantia de verdade" (Lopes e Beividas, 2009, p. 447).

Os autores indicam que a abordagem do jogo de caráter elástico e tensivo que se estabelece entre as modalidades, onde se dá a interação de valores modais do SABER e do CRER, implica a análise de dispositivos semióticos cujas consequências incidem no domínio da persuasão e da argumentação. Sobre tal domínio, chamam atenção para o fato de que: "No final dos anos 80 passados, diferentes semioticistas reconheciam (...) não ter a disciplina cuidado, até então, de desenvolver mais diretamente uma teoria da argumentação ou estudo 
sistemático de uma racionalidade argumentativa" (Lopes e Beividas, 2009, p. 443).

Diante dos estudos, apontados como exíguos, da semiótica da Escola de Paris em relação a "possíveis estratégias sintáxicas e semânticas, modais e tensivas, que possam matizar singularmente os movimentos cognitivos da argumentação" (Lopes e Beividas, 2009, p. 444), os autores buscam evitar a confortável postura definida por eles como "ecumênica", que permitiria a importação irrefletida de conceitos já construídos em disciplinas afins, como a retórica, a pragmática e a análise do discurso, e sua transposição direta para o interior da reflexão semiótica. Para tanto, recorrem às definições dicionarizadas dos termos demonstração, argumentação e persuasão, que permitem estruturar uma hierarquia, alicerçada no funcionamento próprio das línguas naturais, relativa ao estatuto lógico dessas três operações:

(...) demonstrar tem um sentido mais lógico, digamos "superior", de estabelecer uma verdade de modo evidente e rigoroso. Num degrau "inferior", argumentar tem menor força lógica, a de apresentar razões ou raciocínios para se obter uma conclusão. Por fim, persuadir, no degrau menos nobre da hierarquia, embora o mais abrangente, é levar a pensar, a querer, a crer, a fazer (através da adesão completa, tanto sentimental quanto intelectual). (Lopes e Beividas, 2009, p. 445)

A partir dessa estruturação hierárquica, é possível caracterizar semioticamente de forma mais detalhada o jogo elástico entre valores modais do CRER e do SABER que se instaura no interior das situações intersubjetivas de comunicação. Ao percorrermos a série de três termos desse modo hierarquizados, partindo da demonstração, passando pela argumentação e chegando à persuasão, "revelam-se dois movimentos tensivos: uma diminuição do SABER acoplada a um aumento do CRER nessa mesma ordem" (Lopes e Beividas, 2009, p. 445). Isso ocorre porque:

Uma demonstração se fundamenta no saber e prescinde do crer ou minimiza-o; uma argumentação tenta fazer prevalecer um saber (novo) sobre o crer (anterior); e uma persuasão promove um crer 
adesivo, ainda que, para fazê-lo, tenha de atropelar algum saber. (Lopes e Beividas, 2009, p. 446)

A abordagem assim ancorada nas modalizações sintáticas inscritas nos discursos privilegia o enfoque dos movimentos elásticos entre o CRER e o SABER no interior da comunicação. Tal aproximação teórica é especialmente cara à semiótica por esta ser uma ciência que "diferentemente das teorias da comunicação então correntes", "entendeu que a comunicação entre os homens é menos transferência ou transmissão de informações, um fazer-saber, e mais um contrato fiduciário, incidente sobre o crer, um fazer-crer" (Lopes e Beividas, 2009 , p. 446). Ainda de acordo com os autores, "noutros termos, sem garantias de uma verdade intrínseca do mundo, nosso pouco de saber sobre o mundo está plenamente invadido pelo nosso crer nos outros" (2009, p. 446).

Munidos dessas ferramentas, um dos aspectos analisados no conto de Guimarães é justamente a elasticidade tensiva entre o CRER e o SABER, modalidades que emergem discursivamente na ação narrada, em que um jagunço, renomado assassino local, confronta um médico, único homem culto e instruído de um pequeno vilarejo sertanejo, sobre o significado da palavra que dá nome ao conto, famigerado. As oscilações modais, já enquadradas no gradiente tensivo subjacente à hipótese central do artigo de que o CRER tensiona e o SABER distensiona, caracterizam preponderantemente o fazer-interpretativo dos dois sujeitos que protagonizam a ação.

Damázio, o temível jagunço, é chamado de "famigerado" e, não sabendo se a alcunha consiste em insulto ou elogio, coloca-se à porta do médico, o narrador do conto, em companhia de outros três jagunços, para passar a limpo o significado do termo em questão. A partir daí, "o texto gerencia, portanto, os ascensos e descensos de tensão pela ótica desse narrador, surpreendido, um dia qualquer, pela chegada a sua casa daquele grupo de cavaleiros desconhecidos" (Lopes e Beividas, 2009, p. 449).

A proposta inicial de análise das "modulações tensivas do medo e das paixões correlatas" e das "formas de raciocínio inferencial mobilizadas pelas personagens do relato, e notadamente as ilações abdutivas ${ }^{20}$ postas em cena"

20 A definição de abdução empregada pelos autores é a de Peirce (2009): "A abdução é o processo de formulação de uma hipótese explicativa. (...) A dedução prova que algo deve ser. A indução mostra que algo é operatório de fato. A abdução apenas sugere que algo pode ser". Peirce, C. S. Collected papers: pragmatism and pragmaticism. V. 5. Disponível em: http:// www.textlog.de/7658.html. Acesso em 29/7/2013. 
(Lopes e Beividas, 2009, p. 443) encontra vasto material semiótico na narrativa onde se encontram imbricados dois sujeitos: de um lado, Damázio, sujeito do não-SABER que crê ter sido ofendido; do outro, o médico narrador da ação, sujeito tido por Damázio como competente e detentor de um SABER pressuposto pelo exercício de sua profissão, mas que, tomado de medo, define seu estado como o de "extrema ignorância em momento muito agudo" (Rosa, 1985, p. 14) por desconhecer (não-SABER) o motivo que levara até sua porta o jagunço mais perigoso daquelas bandas:

Desde esse instante, o medo e os sentimentos conexos assaltarão o narrador com intensidade variando em função daquilo que, a cada momento, ele pode diretamente observar (a linguagem somática sincretizada no comportamento de seus visitantes, por exemplo) e das inferências que irá fazendo a partir de tais observações, somadas aos saberes e crenças constitutivos de sua posição social (médico do vilarejo). Para o leitor, podemos esquematicamente dizer que as coisas reportadas como observadas pelo narrador são da ordem do saber, ao passo que as coisas inferidas por ele são, em princípio, da ordem do crer. (Lopes e Beividas, 2009, p. 449)

Nesse sentido, o quadro modal do narrador caracteriza-se inicialmente por uma acentuada presença do CRER (visto que, diante da surpresa da chegada de Damázio, a quantidade de dados inferidos ultrapassa a dos observados), que convoca vivamente a dimensão tímica para dentro de seu fazer-interpretativo e contribui para o aumento da tensão narrativa.

Num segundo momento, porém, quando o médico compreende o motivo da visita de Damázio e se dá conta de que é capaz de manejar a situação de modo que sua segurança seja garantida, ou seja, respondendo ao jagunço que famigerado significa "famoso" e é um elogio, a quantidade de dados observados, da ordem do SABER, sobrepujam o apenas observado, o que engendra a distensão narrativa. De acordo com os autores, "o final da narrativa estabiliza um estado distenso para o médico/narrador, mas isso se dá ao cabo de uma série de oscilações tímicas ao longo das quais ele, o interpelado (...), percorrerá diversos valores da escala passional centrada no medo" (Lopes e Beividas, 2009, p. 448).

Assim, a hipótese inicial de que "o crer tensiona e o saber distensiona. Mais e mais crer, maior tensão; mais e mais saber, maior distensão" (Lopes e Beividas, 
2009, p. 447) é observada e validada nesse conto de Rosa. Parece-nos pertinente, porém, atentar para o fato de que, se é um SABER que distende o estado tensivo do médico, Damázio apazigua-se por meio de um CRER. Ele crê que "famigerado" significa "importante", pois assim lhe informou o doutor. Mas não sabe que, no final das contas, o termo também pode ser um insulto ao assumir outro de seus sentidos possíveis: "aquele que tem má fama”.

Temos assim formulada uma contra-hipótese, segundo a qual o CRER distensiona e o SABER tensiona. Essa é uma formulação que Lopes e Beividas não descartam em seu artigo: os autores a preservam como hipótese possível e a mantém, junto de sua contraparte, por eles demonstrada, como duas inconclusividades que merecem maior investigação.

\subsection{Contra-hipótese e a questão do CRER no discurso religioso}

De fato, por ocasião da apresentação do conteúdo de "Argumentação e Persuasão: Tensão entre Crer e Saber em 'Famigerado', de Guimarães Rosa” em um congresso, o prof. Dr. Ivã Carlos Lopes comentou, em fala no IX Minienapol de Semiótica ${ }^{21}$, que um dos presentes na plateia, ao fim de sua exposição, apontou que no interior de uma religião a máxima crença propicia a máxima distensão. Esse é um arranjo tensivo relevante junto às práticas ${ }^{22}$ religiosas que propalam que na maior crença, no mais elevado grau de adesão à doutrina e de fé, o sujeito encontraria o mais consistente estado de apaziguamento, de conforto, ou seja, a maior distensão.

Por um lado, o princípio de que o CRER tensiona e o SABER distensiona mostra-se bastante pertinente e comumente observável para a prática e ética discursiva mundana, no sentido de oposta à religiosa. De fato, seu funcionamento

21 Encontro dos Alunos de Pós-Graduação em Semiótica e Linguística Geral, evento realizado na FFLCH - USP, em outubro de 2010.

22 A noção de prática é empregada aqui no sentido definido por Fontanille em seu artigo Pratiques sémiotiques: immanence et pertinence, efficience et optimisation (2006, p. 5): “As práticas recebem uma 'forma' (constituintes) de sua confrontação com outras práticas e, por isso, de um lado, integram os elementos materiais dos níveis inferiores (signos, textos objetos) para torná-los elementos distintivos e pertinentes e lhes dar 'sentido' e, de outro lado, recebem 'sentido' de sua própria participação nos níveis superiores (estratégias e formas de vida)”. 
foi atestado também em nosso estudo de Iniciação Científica ${ }^{23}$ (2010), que se ocupou da análise dos sujeitos Paulo Honório e Anna Karênina, respectivamente protagonistas dos romances São Bernardo, de Graciliano Ramos, e Anna Karênina, de Leon Tolstói. Nesse trabalho, observamos, para ambos os textos, um acréscimo de tensão narrativa associada à ativação dos valores modais do CRER no fazerinterpretativo dos sujeitos sob análise, seguido de distensão promovida pelo aumento do SABER, e consequente diminuição do CRER, no desfecho narrativo.

Tanto Paulo Honório quanto Anna, sujeitos de um CRER ascendente que eleva, consigo, a tensão narrativa até o clímax, só conhecem a distensão quando, ao fim de seus percursos narrativos, experimentam um aumento do SABER em relação ao CRER, ascensão figurativizada pelo desvelamento de uma verdade. Paulo Honório descobre que sua mulher, Madalena, diferentemente do que ele acreditava, nunca o havia traído em vida, e que o que ele guardava há anos na carteira como a prova do adultério, uma página de carta de amor escrita por ela supostamente a outro homem, consistia na verdade em um texto endereçado a ele: "Sobre a bancada de Madalena estava o envelope de que ela me havia falado. Era uma carta extensa em que se despedia de mim. (...) Faltava uma página: exatamente a que eu trazia na carteira (...)" (Ramos, 1979, p. 165 - 166). Já no texto de Tolstói, o aumento do SABER e diminuição do CRER surge na figura da chama de uma vela que, na ação final da narrativa, o suicídio de Anna, brilha intensamente iluminando todo o livro da vida da heroína, especialmente as páginas que haviam permanecido até então na penumbra:

E a vela, à luz da qual Ana lera o livro da vida com todos os seus tormentos, todas as suas traições e todas as suas dores, resplandeceu, de súbito, com uma claridade maior do que nunca, alumiando as páginas que até então haviam estado na sombra. Depois crepitou, estremeceu e apagou-se para sempre. (Tolstói, 1971, p. 705)

O SABER, porém, parece não assumir tal papel de modalidade promotora da distensão na prática religiosa. Nesta, o SABER não apazigua, mas antes incomoda, porque vem a cindir o objeto e a subverter os valores aí aderidos. A conservação

23 Pereira, E. D. Crer-ser: as ilusões de verdade de Anna Karênina e Paulo Honório. Iniciação Científica em Semiótica e Linguística Geral. Faculdade de Filosofia, Letras e Ciências Humanas, Universidade de São Paulo, São Paulo, 2010. Orientação: Waldir Beividas. 
dos objetos é tida como eufórica na lógica cristã e apontada como um efeito do CRER por Zilberberg no seguinte trecho de Razão e poética do sentido:

Parece que aí, mais uma vez, as modalidades do saber e do crer cifram de modo diferente seu objeto: a modalidade do crer privilegia os valores emissivos e poderíamos falar nesse caso de perobjeto. Assim, quando Proust diz "Lá onde reinam as crenças, os fatos não entram”, o elemento notável não é a oposição, no fundo banal, entre crer e saber, mas o modo pelo qual essa oposição é traduzida em significado (...): "reinar" propõe, de modo tautológico, uma dominância e "entrar" atribui a esta dominância uma figuralidade dicotômica, a de um "dentro" e de um "fora". A partir daí, uma narratividade elementar categoriza a "crença" como defensiva e os "fatos" como ofensivos.

Ao contrário, a modalidade do saber acentua os valores remissivos e tudo parece indicar que, se o crer conserva seu objeto, o saber, por sua vez, o extenua de tal forma que poderíamos conceber aqui o termo an-objeto. Se pensarmos na prática da adivinhação, da charada, do enigma, a operação cognitiva anula seu objeto no instante em que o apreende! Mas o que vale para o gesto infantil vale também para os procedimentos mais elevados. (Zilberberg, 2006, p. 142 - 143)

A partir dessa formulação, Zilberberg dá o exemplo da estética que, enquanto prática significante, "é conservadora, como um culto, uma devoção". Tal conservação de seus, assim, perobjetos é tanto pragmática, que "existe por criação de um 'reduto' no espaço social ou idioletal: museu, cripta, paredes de caverna...", quanto cognitiva, "sempre por clivagem do espaço: o não-saber (...) advém por divisão e compartimentação do espaço enquanto o saber, como processo, é apenas a resolução, a reabsorção dessa clivagem”. Desse modo, a atividade estetizante é considerada por Zilberberg, do ponto de vista cognitivo, como uma confissão do caráter "enigmático" ou "obscuro" das obras, e, uma vez que uma grandeza seja modalizada como um perobjeto, sua relação com o CRER e o SABER é definida pelo autor da seguinte forma: "Numa palavra, o saber consome-o, o crer soma-o" (Zilberberg, 2006, p. 144).

Propomo-nos, então, analisar, discutir e pensar semioticamente o CRER na prática discursiva religiosa. Para tanto, elegemos como objeto de análise uma 
cena do longa-metragem Doubt ${ }^{24}$ (2008), de John Patrick Shanley, em que o CRER e o SABER são postos em jogo no sermão do padre Flynn, protagonista da ação, que tematiza a dúvida em sua fala e valora, de acordo com uma prática e uma ética cristãs, as modalidades por nós investigadas.

Lançamo-nos à análise desse texto mantendo em mente as duas inconclusividades sinalizadas por Lopes e Beividas (2009), ou seja, a hipótese de que o CRER tensiona e o SABER distensiona ao lado de sua contraparte: o CRER distensiona e o SABER tensiona. Munimo-nos, em termos de base teórica mais geral, da definição da semiótica da Escola de Paris para a dúvida, concebida como uma categoria modal diretamente relacionada às modalidades epistêmicas e às atividades cognitivas empreendidas pelo sujeito para saber ou conhecer algo sobre o seu mundo. De forma mais específica, retomamos as formulações encontradas em “Un point de vue sur 'croire' et 'savoir"” (1982), em que Fontanille, ao delimitar dois universos de racionalidade, um referente ao CRER e o outro, ao SABER, aponta a dúvida como uma operação cognitiva própria do universo do CRER, visto que a operação equivalente no universo do saber seria a contestação.

Ainda segundo o autor, esses dois universos pressupõem juntos um mesmo sujeito cognitivo, suscetível alternadamente ao CRER e ao SABER, e que passa de um sistema a outro por meio de um percurso transgressivo. A noção de percurso transgressivo, como definido por Fontanille em "Un point de vue sur 'croire' et 'savoir"'(1982), é um dos insumos teóricos principais para a análise de nosso objeto. Consideramos, portanto, relevante apresentar a seguir uma súmula do pensamento de Fontanille no referido artigo como um preâmbulo à nossa análise.

\section{$2.4 \mathrm{O}$ ponto de vista de Fontanille}

Fontanille abre o artigo "Un point de vue sur 'croire' et 'savoir"'(1982, p. 5

24 O longa-metragem Doubt (2008) recebeu o título Dúvida em português e se baseia na peça Doubt: A Parable (Dúvida: Uma Parábola), de 2004, escrita por John Patrick Shanley. A peça, originalmente montada em novembro de 2004 no circuito off-Broadway no Manhattan Theatre Club, foi vencedora do Pulitzer Prize for Drama de 2005. A cena sob análise pode ser assistida em http://www.youtube. com/watch?v=xOaBjpXXnaE e sua transcrição completa é encontrada na seção "Anexos" desta dissertação. 
- 31) realizando uma importante distinção. Ela dá conta do fato de que, se, para a lógica, "a avaliação do saber e do crer é limitada à sua relação com a verdade, ou seja, a um sistema de dois valores não hierarquizável”, para a semiótica essa avaliação só pode se fundar em "relações de adequação, internas ao enunciado". Se admitirmos que o ato de conhecer o mundo "ato epistêmico", como denominado por Greimas) é um fazer avaliativo de um sujeito interpretativo que se aplica a determinado enunciado de estado, podemos, segundo Fontanille, definir a adequação cognitiva como "o conjunto de sobremodalizações aplicadas a este enunciado, e que constituem a prova qualificante do sujeito interpretativo". Fica assim instaurado o que busca o artigo de Fontanille: identificar e descrever um ou mais modelos de adequação cognitiva. Para tanto, o autor se volta a quatro Diálogos de Platão (Protágoras, Eutidemo, Górgias e Mênon), visando abandonar progressivamente a superfície dos textos a fim de isolar operações discursivas subjacentes à transmissão de conhecimentos.

A primeira das relações intersubjetivas analisada é a fundada no CRER e na confiança (relação entre S1 mestre e S2 discípulo, por exemplo). Fontanille a aborda a partir de três operações que formam um sintagma intersubjetivo: a operação entre S1 e S2, um fazer persuasivo (onde S1 afirma que sabe, S1 triunfa sobre os demais, $\mathrm{S} 1$ crê estar entre aqueles para os quais pode se mostrar superior, S1 não discute à maneira dos outros, mas à sua maneira, etc.); a operação entre $\mathrm{S} 2$ e O (o saber), um fazer epistêmico (onde Fontanille destaca a existência de uma ladainha de adesão, identificada em expressões pelas quais o interlocutor S2 participa da sua própria manipulação. Elas podem decorrer somente do exame do O cognitivo proposto, como "me parece que", "é assim", "exato", ou depender de maneira determinante do domínio do mestre, como "estou de acordo", "você tem razão", "sem dúvida", "forçosamente"); e finalmente a operação entre S2 e S1, um fazer fiduciário em que S2 faz um julgamento favorável de $\mathrm{S} 1, \mathrm{~S} 2$ é seduzido pela maneira de $\mathrm{S} 1$ falar, S2 supõe que S1 tem experiência suficiente, etc. Nessa relação intersubjetiva, S2 reconhece a competência e a superioridade de S1 e aceita não só o contrato explícito, mas também os implícitos.

O aspecto que nos é relevante aqui é o fato de que, nesse tipo de cena enunciativa, "o interlocutor não tem tempo de avaliar ele mesmo o objeto proposto. $\mathrm{O}$ orador usa seu poder de persuasão para introduzir, do exterior, um conhecimento inverificável e, portanto, admitido sem exame”. De forma análoga, o mesmo ocorre nos tribunais, em relação aos quais Sócrates defende: "o orador não está preparado para instruir os tribunais e os outros na assembleia sobre 
o justo e o injusto, ele pode apenas dar a eles crenças". A essa altura do artigo, é sublinhado que os textos de Platão também mostram que o universo do SABER é aquele em que o indivíduo se aventura e assume o risco da hostilidade e do ostracismo: "A ligação das disciplinas à pessoa moral e física do mestre no universo do crer, que se traduz por uma identificação, se opõe à ligação às ideias, defendida por Sócrates" (Fontanille, 1982, p. 10). A partir de tal análise empírica e indutiva dos textos de Platão, aos quais se encontra aderido o pensamento socrático, Fontanille nos apresenta a esquematização dos universos axiológicos do CRER e do SABER, que descreve "dois universos de racionalidade" (retomamos aqui o quadro já visto na p. 31 desta dissertação, agora seguido de comentários mais detidos sobre seus termos):

\begin{tabular}{|c|c|c|}
\hline & Crer & Saber \\
\hline Conteúdos cognitivos & $\begin{array}{c}\text { crenças } \\
\text { ("conhecimento falso") }\end{array}$ & $\begin{array}{l}\text { ciências } \\
\text { ("conhecimento } \\
\text { verdadeiro") }\end{array}$ \\
\hline Estratégia cognitiva & Persuasão & convicção \\
\hline $\begin{array}{c}\text { Origem do } \\
\text { conhecimento } \\
\end{array}$ & $\begin{array}{l}\text { S1 (exterioridade) } \\
\text { por manipulação }\end{array}$ & $\begin{array}{l}\mathrm{S} 2 \text { (interioridade) } \\
\text { por reminiscência }\end{array}$ \\
\hline Relação ao objeto & $\begin{array}{c}\text { imediata } \\
\text { não aspectualizada }\end{array}$ & $\begin{array}{l}\text { mediata, aspectualizada, } \\
\text { com resistência do objeto }\end{array}$ \\
\hline $\begin{array}{c}\text { Relação dominante } \\
\text { no sintagma } \\
\text { intersubjetivo }\end{array}$ & $\begin{array}{c}\mathrm{S} 2-\mathrm{S} 1 \\
\text { (ligação às pessoas) }\end{array}$ & $\begin{array}{c}\mathrm{S} 2-\mathrm{O} \\
\text { (ligação às ideias) }\end{array}$ \\
\hline Figuras dominantes & $\begin{array}{c}\text { consenso, acordo, } \\
\text { identidade }\end{array}$ & $\begin{array}{c}\text { desacordo, discussão, } \\
\text { alteridade }\end{array}$ \\
\hline
\end{tabular}

(Fontanille, 1982, p.11)

Mais adiante, Fontanille postula que "todas as diferenças entre os dois universos de conhecimento parecem depender em profundidade da relação do sujeito em respeito ao conhecimento, uma relação de dominação reversível": 


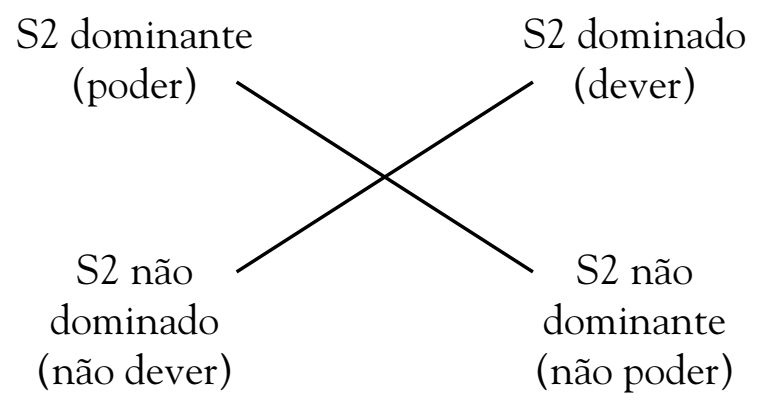

(Fontanille, 1982, p. 12)

Essa é a axiologia relacional sobre a qual se funda a oposição entre os dois universos cognitivos. Temos, assim, que a "modalização própria aos objetos da crença é o dever-ser, porque ela remete à dominação de um outro sujeito (S1), e que a modalização própria aos objetos do SABER é o poder-ser, porque ela remete estritamente ao desejo de domínio cognitivo do sujeito S2 sobre o objeto" (Fontanille, 1982, p. 12). Dessa forma, Fontanille também aponta que a oposição entre CRER e SABER é o equivalente cognitivo da oposição geral entre manipulação e ação. Sendo assim, quando os objetos circulam no universo do SABER, eles percorrem o seguinte sistema:

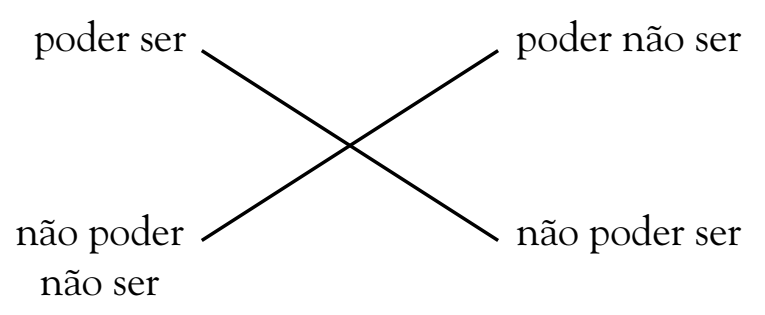

(Fontanille, 1982, p. 14)

E, quando circulam no universo do CRER, percorrem o sistema seguinte:

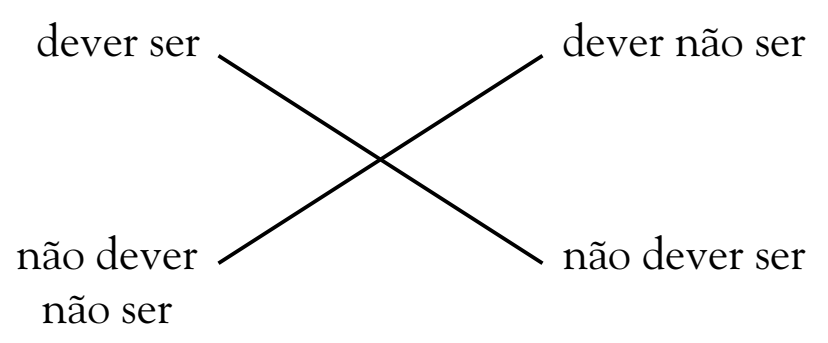

(Fontanille, 1982, p. 14) 
Em decorrência, as operações de adequação cognitiva são as seguintes:

a) Operações "científicas" (dominadas pelo SABER e denominadas "convicção" por Sócrates):

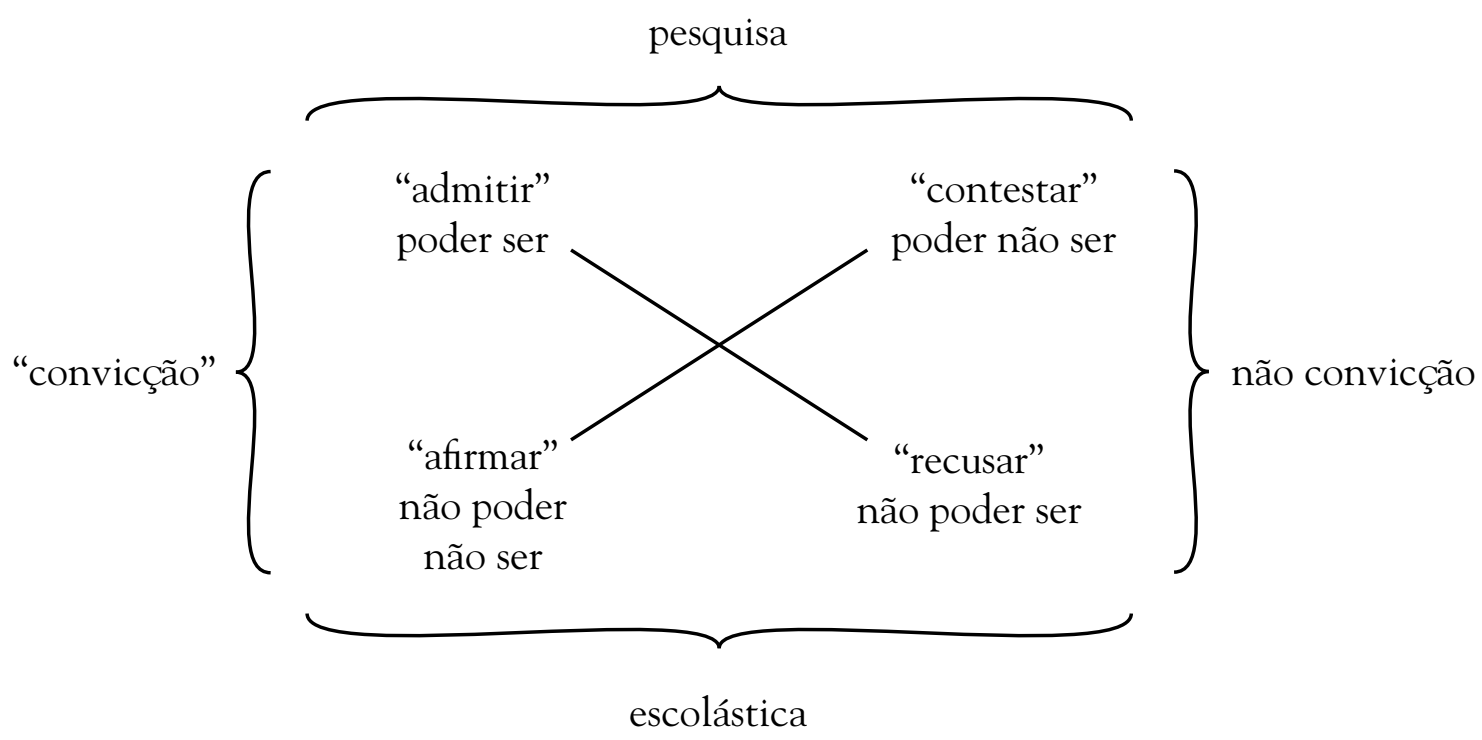

(Fontanille, 1982, p. 20)

b) Operações "fiduciárias" (dominadas pelo CRER e denominadas "persuasão" por Sócrates):

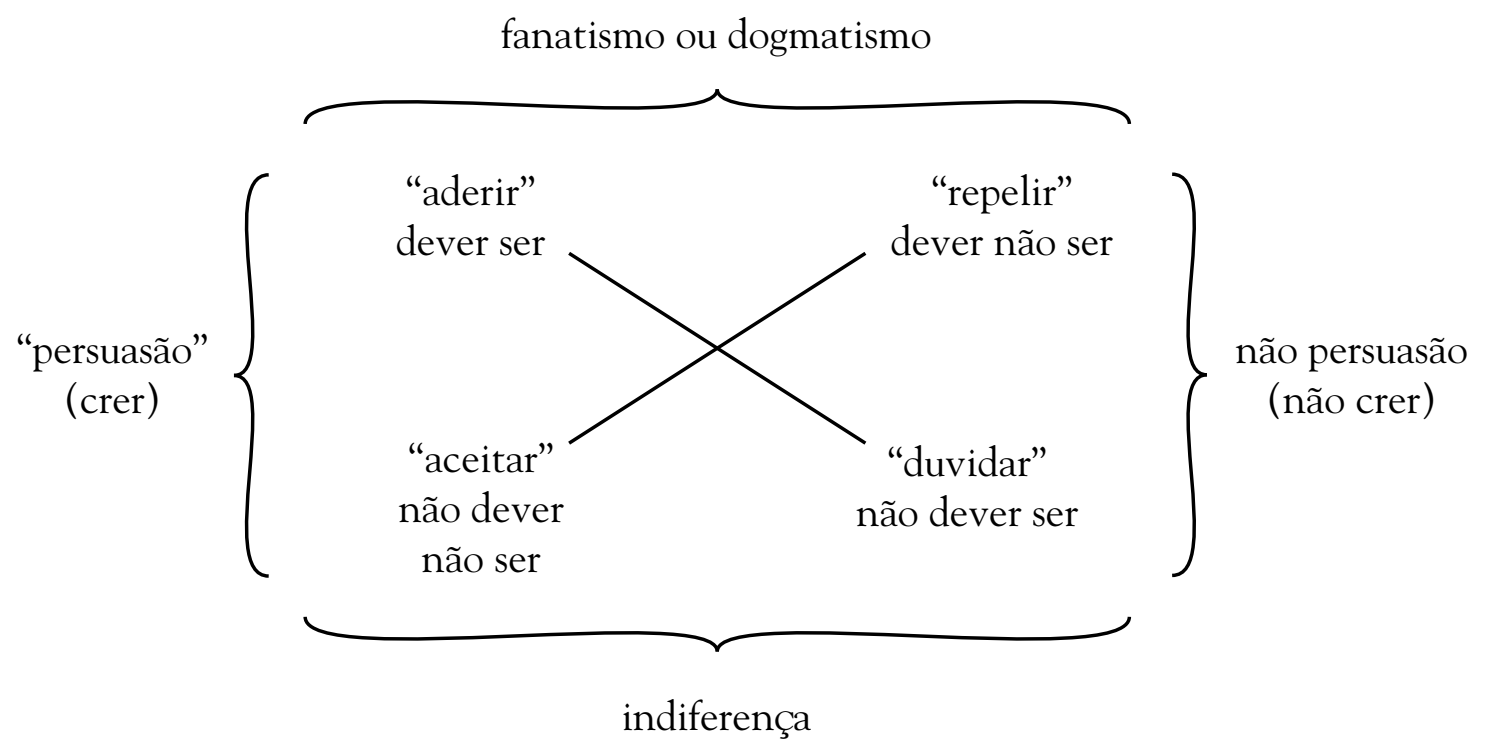

(Fontanille, 1982, p. 20) 
A partir disso, o procedimento teórico que enseja a noção semiótica de percurso transgressivo é a homologação dos quadrados das modalidades aléticas /dever-ser/ e /poder-ser/. A homologação é dirigida pelo fato de que, como já descrito por Greimas e Courtés em seu Dicionário de Semiótica (2008), os termos /não poder não ser/ e /dever ser/ "mesmo repousando apenas em uma intuição semântica", se encontram em "relação de complementaridade"(Greimas e Courtés, 2008, p. 373). Assim, “a necessidade, por exemplo, seria um não poder não ser que pressupõe um dever-ser" (Greimas e Courtés, 2008, p. 373). Devido a essa especificidade inerente às modalidades aléticas, os quadrados são homologados de maneira invertida. Para Fontanille, "essa solução evidencia singularmente a ligação paradoxal que une os dois sistemas" (do SABER e do CRER) (Fontanille, 1982, p. 22). O resultado é o seguinte:

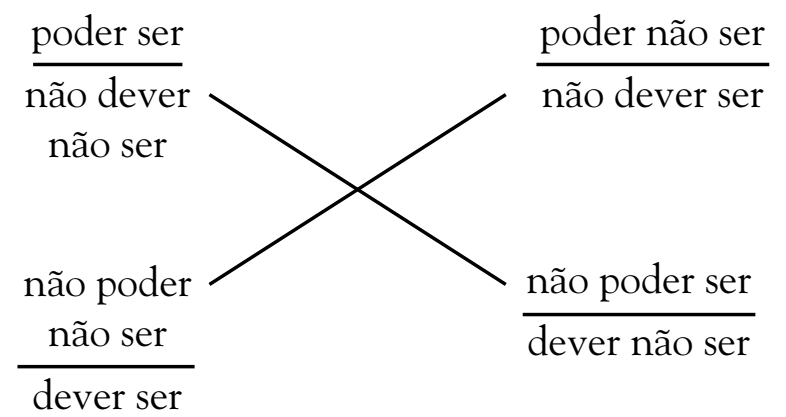

(Fontanille, 1982, p. 23)

A partir da homologação das modalizações, temos em consequência a homologação das operações cognitivas:

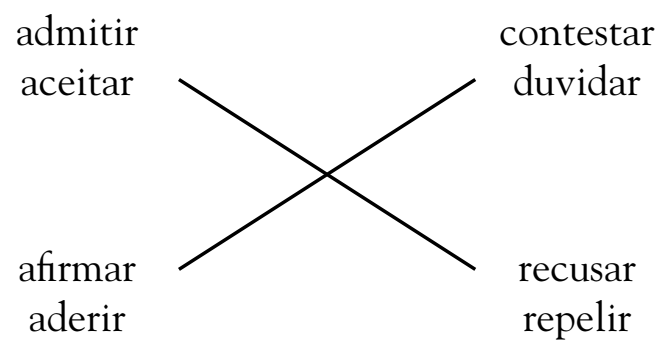

(Fontanille, 1982, p. 25)

As duas formulações homologadas apresentadas acima são "contraditórias, porque independentes no plano axiológico, mas complementares, porque pressupõem juntas um mesmo sujeito cognitivo, suscetível alternadamente ao 
crer e ao saber" (Fontanille, 1982, p. 24). É essa mobilidade do sujeito entre os dois sistemas modais no exercício de sua adequação cognitiva que o percurso transgressivo capta e representa teórica e graficamente. A adequação é uma operação cognitiva dinâmica, em que “crenças' e 'saberes' se virtualizam uns aos outros. Quando as operações de adequação são atualizadas em um sistema, elas são virtualizadas no outro" (Fontanille, 1982, p. 27). A representação gráfica para a dinâmica das operações cognitivas e circulação do sujeito entre os dois universos de racionalidade, o SABER e o CRER, é a seguinte:

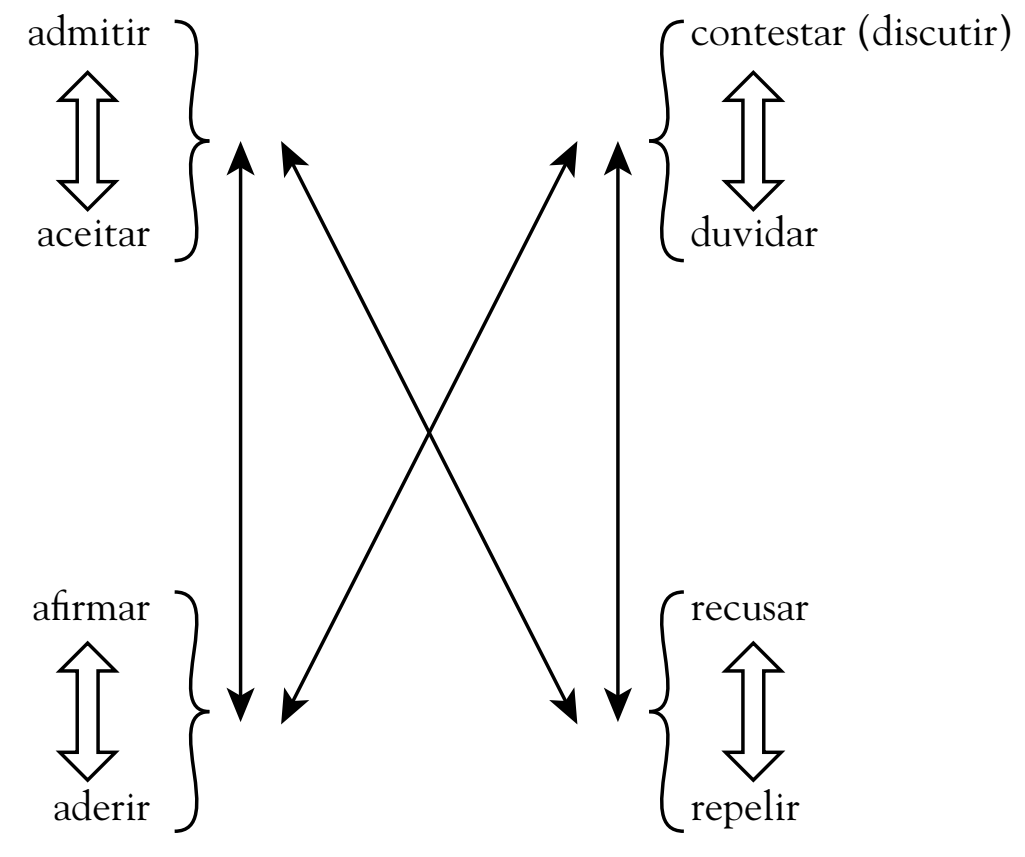

$\longleftrightarrow$ transformações sobre o quadrado epistêmico, comuns aos dois sistemas, visto que cada modificação em um pressupõe uma modificação virtual no outro; estes são os percursos regressivos (negação) e progressivos (afirmação).

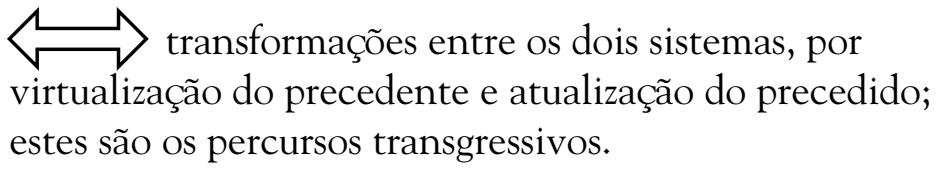
estes são os percursos transgressivos.

(Fontanille, 1982, p. 28)

Assim, a transformação (da qual, como vemos, a transgressão configura um caso particular) situada na dimensão das modalidades, que é definida de forma geral em termos de negações ou afirmações por Greimas, como em "o crer por vezes repousa, e até mesmo se consolida, sobre a negação de um saber" (1983, p. 116), ganha especificações de âmbito operacional em Fontanille. Podemos 
observar, em seu modelo descritivo, que a suspensão (virtualização) de um SABER para que um CRER se instaure (se atualize) implica que o sujeito cumpra um percurso construído por operações cognitivas já projetadas na estrutura elementar da significação, o quadrado semiótico, e próprias a cada sistema, sobre as quais, então, o sujeito atua por meio de afirmações ou negações.

Da dúvida, por exemplo, o sujeito pode ir à contestação (em percurso transgressivo) e, então, à refutação (em percurso progressivo), saindo do universo do CRER em direção a um SABER. Esse é exatamente o percurso transgressivo inscrito em nosso objeto de análise, a cena do sermão do padre Flynn, no filme Doubt (2008).

\subsection{Dúvida e percurso transgressivo - uma análise de cena do longa-metragem Doubt}

É só a dúvida que nos une e nos aproxima. É só disso que precisamos. Não acredito que haja nada verdadeiro. Tenho muito medo da verdade. Tive um professor de filosofia, o padre Henrique Vaz, a quem perguntei: "O que é a fé?". Ele me respondeu que a fé é a dúvida, porque somente ela nos é possivel.

Bartolomeu Campos de Queirós 


\subsubsection{Prática e ética religiosas: a retenção do percurso transgressivo}

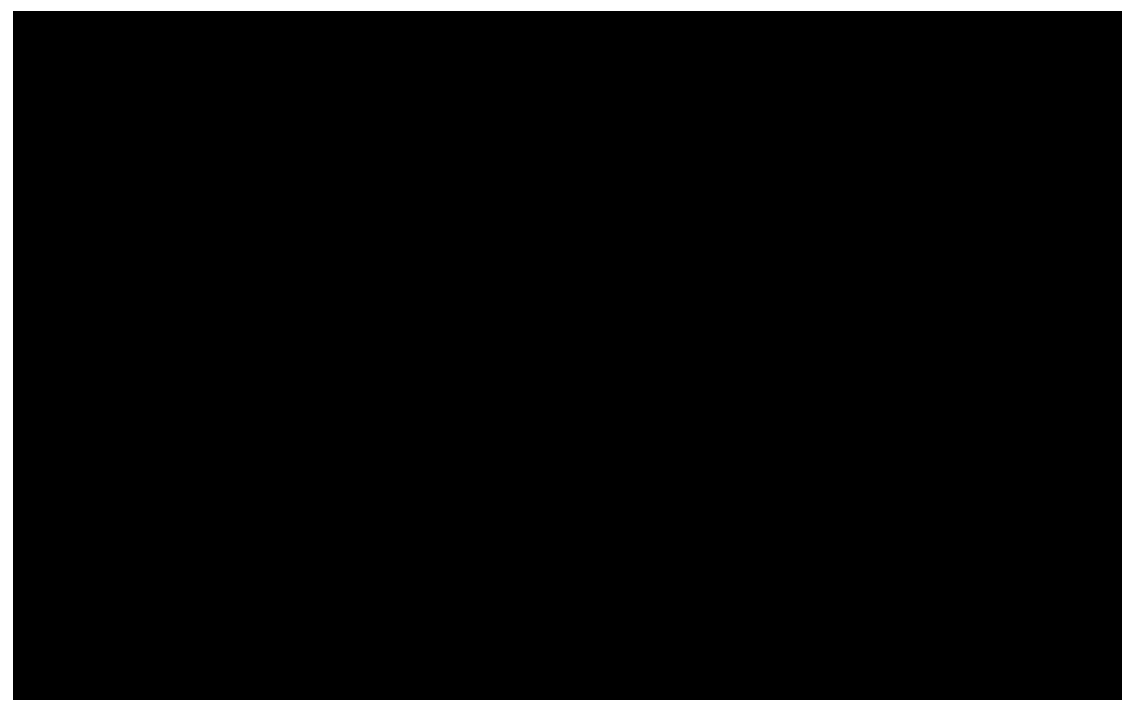

"O que você faz quando não tem certeza?", é com essa pergunta que padre Flynn inicia seu sermão em uma igreja católica no ano de 1964. Na cena enunciativa de um sermão, temos de antemão estabelecidos os actantes S1 (padre Flynn), S2 (audiência) e o objeto cognitivo (conteúdo do sermão/conhecimento). A pergunta do padre, que pressupõe a possibilidade de dúvida (ausência de certeza) junto à comunidade católica, inquieta a irmã Aloysius que, mais tarde, reunida com as demais irmãs para a ceia, questiona:

Por quê (por que o tema do sermão havia sido a dúvida)? Bem, sermões vêm de algum lugar, não é? O padre Flynn está em dúvida? Ele está preocupado que alguma outra pessoa esteja em dúvida? (...) Eu quero que todas vocês fiquem alertas. Eu estou preocupada, talvez desnecessariamente, com os sermões na Escola São Nicolas. (Doubt, 2008, cena a partir do minuto 16'35”)

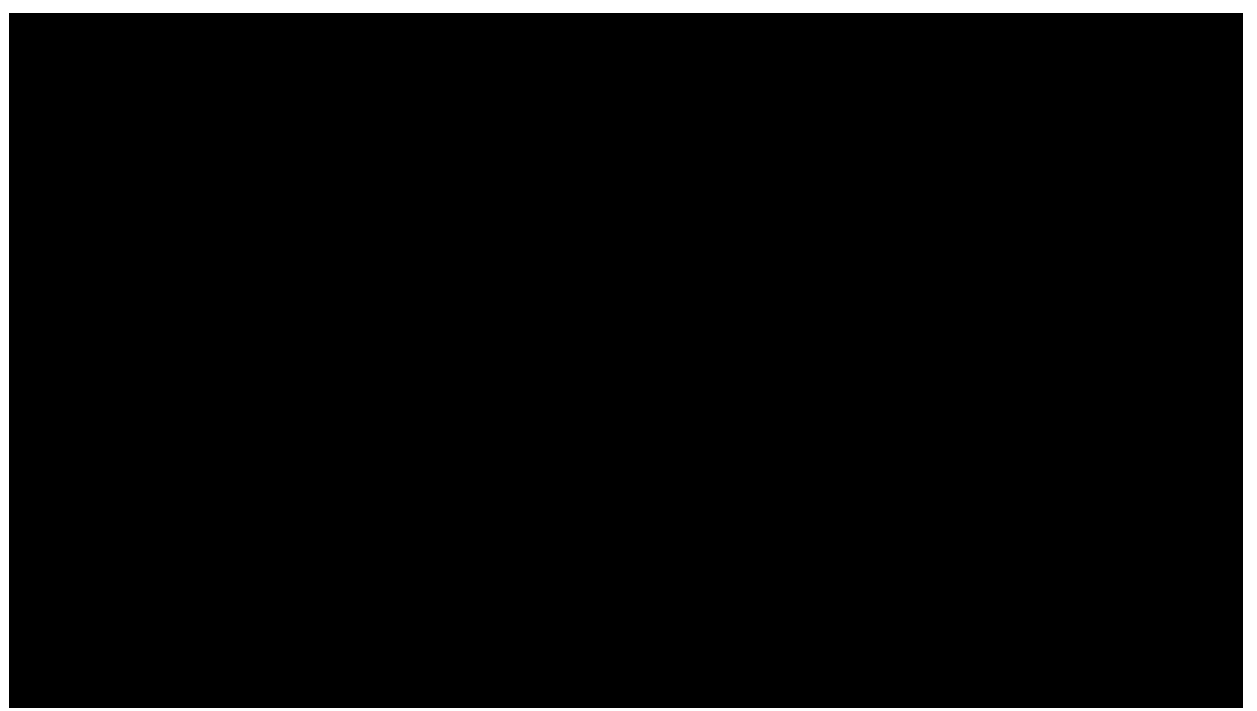


A preocupação da irmã se justifica na medida em que o discurso religioso, que instaura uma prática e uma ética religiosas, se organiza em torno da lógica da Palavra Revelada, a palavra fundadora contida na Bíblia, responsável pela cena enunciativa fundante da Igreja Católica. Encontramo-nos aqui em uma esfera onde não há espaço para qualquer opacidade (nem mesmo a opacidade própria da linguagem, visto que a palavra é revelada), onde o sujeito se afasta das contradições e se coloca sob a certeza da fé inquestionável.

Em relação ao discurso fundador e aos discursos que dele derivam, como se podem caracterizar os discursos de divulgação religiosa, e também o sermão em análise, Ramos-Silva (2007, p. 26) afirma que "são entendidos como cenas enunciativas complementares". Em tal contexto, forçosamente, não há espaço para a admissão ou enunciação da dúvida. E padre Flynn não só a enuncia, como faz dela o tema de sua fala.

Retomando, porém, as elaborações teóricas providas por Fontanille (1982), não podemos nos esquecer que duvidar configura uma operação cognitiva fiduciária própria do universo do CRER. Sua operação cognitiva equivalente no sistema modal do SABER é a contestação, figura não encontrada no texto em análise. De fato, a ligação entre dúvida e crença é flagrante já na definição dicionarizada daquele termo:

Dúvida: s.f. (1266 cf. IVPM) 1. Ação, estado ou efeito de duvidar, de sentir desconfiança 2. Incerteza entre confirmar ou negar um julgamento ou a realidade de um fato 3 . Hesitação entre opiniões diversas ou várias possibilidades de ação 4. Falta de crença (HOUAISS, 2008, p.1091, negrito nosso)

Ao continuar seu sermão, padre Flynn menciona um acontecimento público, a morte do presidente Kennedy em 1963 (que ocorrera um ano antes), e nos fornece mais evidências de que seu discurso, apesar de tematizar e figurativizar a dúvida, elemento inadmitido pela prática religiosa católica, ancora-se e promove uma racionalidade regida pelo CRER. Sobre o episódio, ele diz: 
No ano passado, quando o presidente Kennedy foi assassinado, quem entre nós não teve a experiência da mais profunda desorientação? Desespero? Qual caminho seguir? E agora? O que digo aos meus filhos? O que digo para mim mesmo? Houve um tempo em que as pessoas ficavam sentadas juntas, unidas por um sentimento comum de desesperança. Mas pense nisso: seu vínculo com o seu companheiro foi o seu desespero. Foi uma experiência pública. Foi horrível, mas nós estávamos juntos nisso. $\mathrm{O}$ quanto pior seria, então, para o homem solitário, a mulher solitária, serem atingidos por uma calamidade privada? (Doubt, 2008, cena a partir do minuto 4'45")

O trecho nos remete à distinção feita por Sócrates e retomada por Fontanille de que "o universo do saber é aquele em que o indivíduo se aventura e assume o risco da hostilidade e do ostracismo. A ligação das disciplinas à pessoa moral e física do mestre no universo do crer, que se traduz por uma identificação, se opõe à ligação às ideias, defendida por Sócrates" (Fontanille, 1982, p.10). A oposição entre público (dimensão da identificação) e privado (dimensão da hostilidade e do ostracismo), como encontrada no artigo de Fontanille, mantém-se no sermão de Flynn. A relação dominante no sintagma intersubjetivo eufórica no discurso é aquela própria do universo do CRER: S1 - S2 (ligação entre pessoas); enquanto a relação disfórica é aquela característica do universo do SABER: S2 - O (ligação às ideias), como podemos observar em:

\begin{tabular}{|c|c|c|}
\cline { 2 - 3 } \multicolumn{1}{c|}{} & Crer & Saber \\
\hline Relação dominante no & $\mathrm{S} 2-\mathrm{S} 1$ & $\mathrm{~S} 2-\mathrm{O}$ \\
sintagma intersubjetivo & (ligação às pessoas) & (ligação às ideias) \\
\hline
\end{tabular}

(Fontanille, 1982, p. 11)

Em seguida, padre Flynn conta uma pequena parábola sobre um marinheiro, narrativa que figurativiza o tema crise de fé, e conclui seu sermão dizendo: 
Alguns de vocês na igreja hoje conhecem exatamente a crise de fé que eu descrevo. E eu quero dizer a vocês: a dúvida pode ser um vínculo tão poderoso e sustentador quanto a certeza. Quando vocês estiverem perdidos, vocês não estão sozinhos. Em nome do Pai, do Filho e do Espírito Santo, amém. (Doubt, 2008, cena a partir do minuto 7'50", negrito nosso)

Se, em um primeiro momento, o discurso de Flynn parece se distanciar de uma prática e uma ética religiosas católicas (ancoradas na certeza inquestionável provinda da Palavra Revelada) por encampar a categoria modal da dúvida e fazer o elogio desta, respaldados por nosso arcabouço teórico, podemos observar que o efeito de sentido de seu sermão é o de manipular S2 (audiência) a agarrar-se à dúvida e nela permanecer. De acordo com as formulações teóricas de Fontanille (1982), podemos afirmar que S1 manipula S2 a permanecer na operação cognitiva fiduciária da dúvida e manter seu sistema modal do CRER atualizado, impedindo-o de realizar o percurso transgressivo, que o levaria da dúvida à contestação (virtualização do CRER e atualização do SABER) e, desta, à refutação, como podemos observar em:

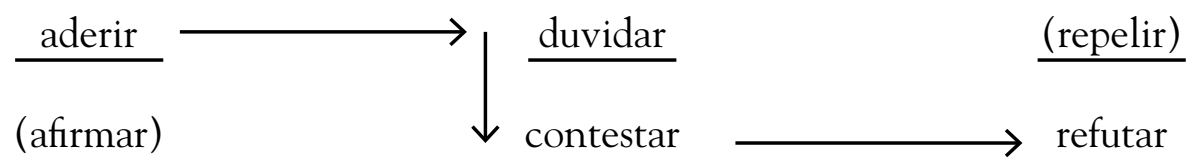

(Fontanille, 1982, p. 26)

Dessa forma, o sermão de padre Flynn mostra-se não convencional por negar os valores de absoluto propalados pela fé católica, mas, ou mesmo tempo, busca reter o sujeito no limiar do sistema modal do CRER, objetivando, talvez, que o percurso regressivo seja realizado e o sujeito retorne à adesão. A admissão da possibilidade de que o sujeito se desloque da adesão à dúvida, figurativizada na parábola que tematiza a crise de fé, revela que padre Flynn faculta ao sujeito alguma dinamicidade em sua operação de adequação cognitiva, algo não previsto na prática católica convencional. De fato, o dinâmico associado ao seu personagem opõe-se ao estático aderido ao papel da irmã Aloysius, sua antagonista ao longo de toda a ação. Tal oposição é explorada semi-simbolicamente pela homologação da ruptura com o convencional e elogio da dúvida (dinamicidade) no plano do conteúdo com o enquadramento diagonal em close ou em plano americano (da cintura para cima) no plano da expressão, como observamos nas figuras A e B a seguir: 
Figura A

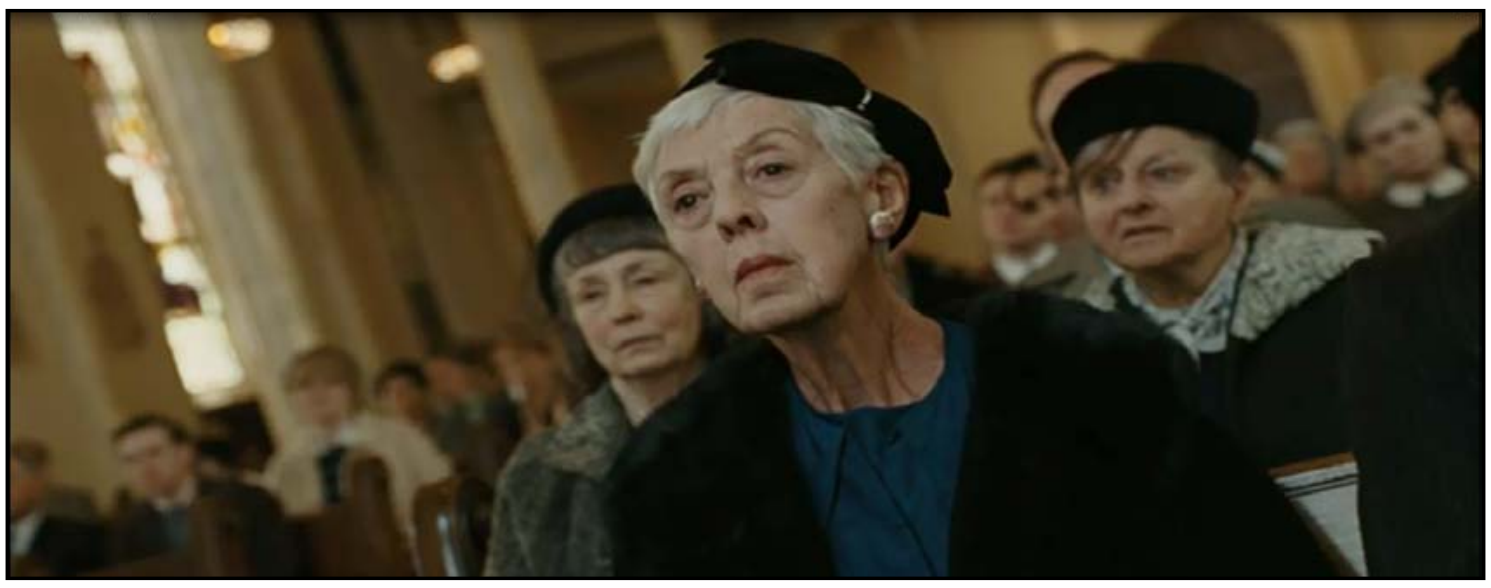

(Doubt, 2008)

Figura B

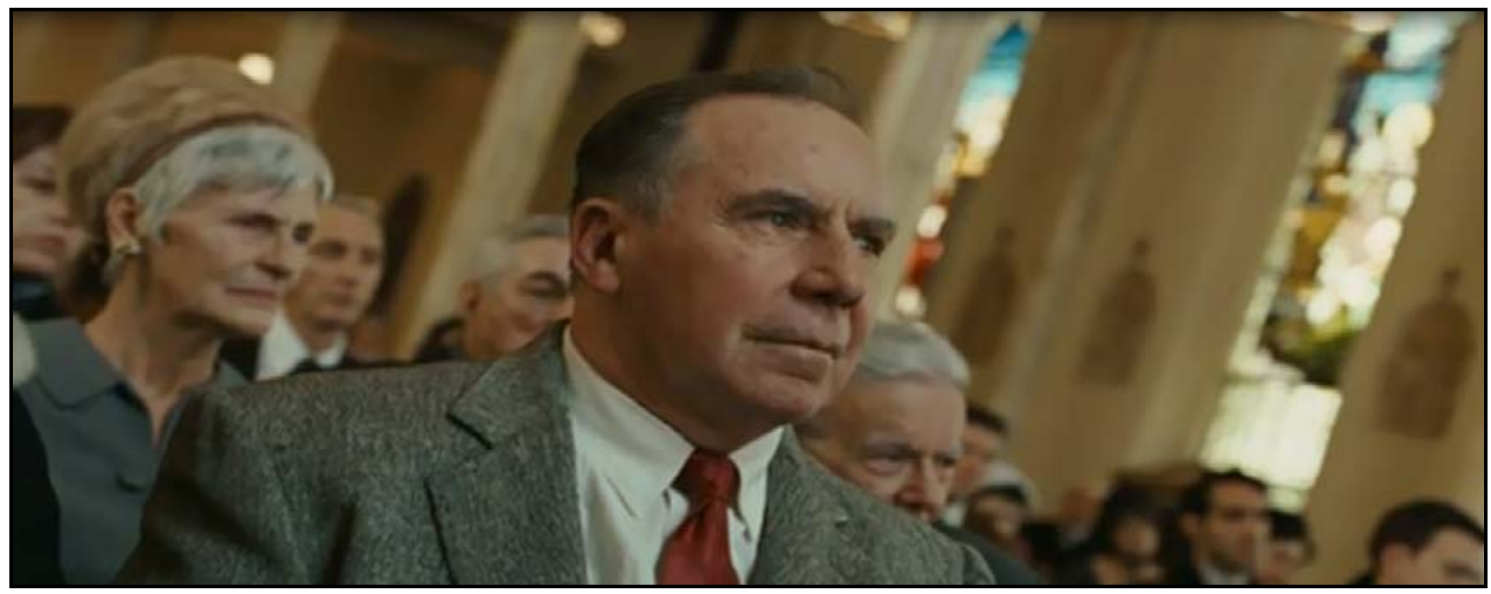

(Doubt, 2008)

É importante observar que o enquadramento diagonal em close ou em plano americano ocorre na direção do olhar do padre Flynn para a sua audiência. Em oposição, o enquadramento ortogonal e em plano afastado se homologa ao estático no plano do conteúdo, que defendemos estar associado à irmã Aloysius. De fato, os enquadramentos ortogonais correspondem à visão que Aloysius tem da cena do sermão, visto que se aproxima lentamente do altar a partir da porta frontal da igreja. Podemos observar nas figuras C e D exemplos de enquadramentos ortogonais em plano afastado: 
Figura C

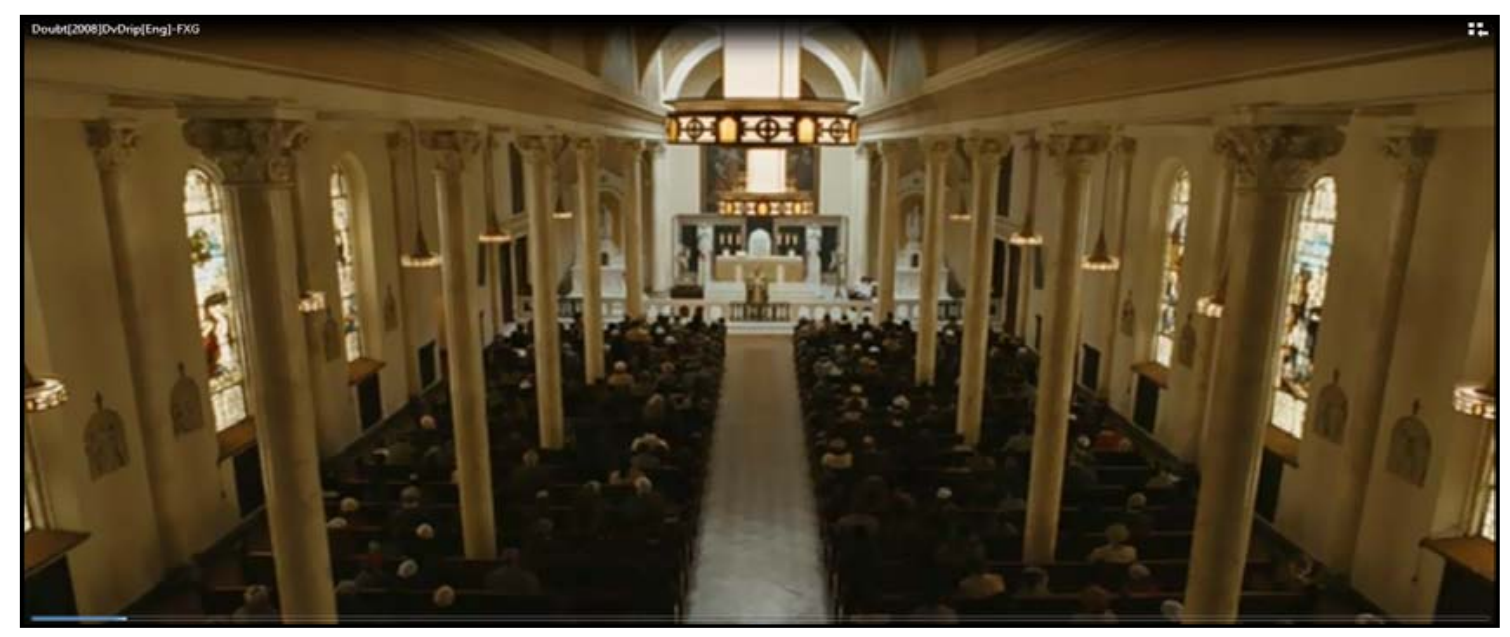

(Doubt, 2008)

Figura D

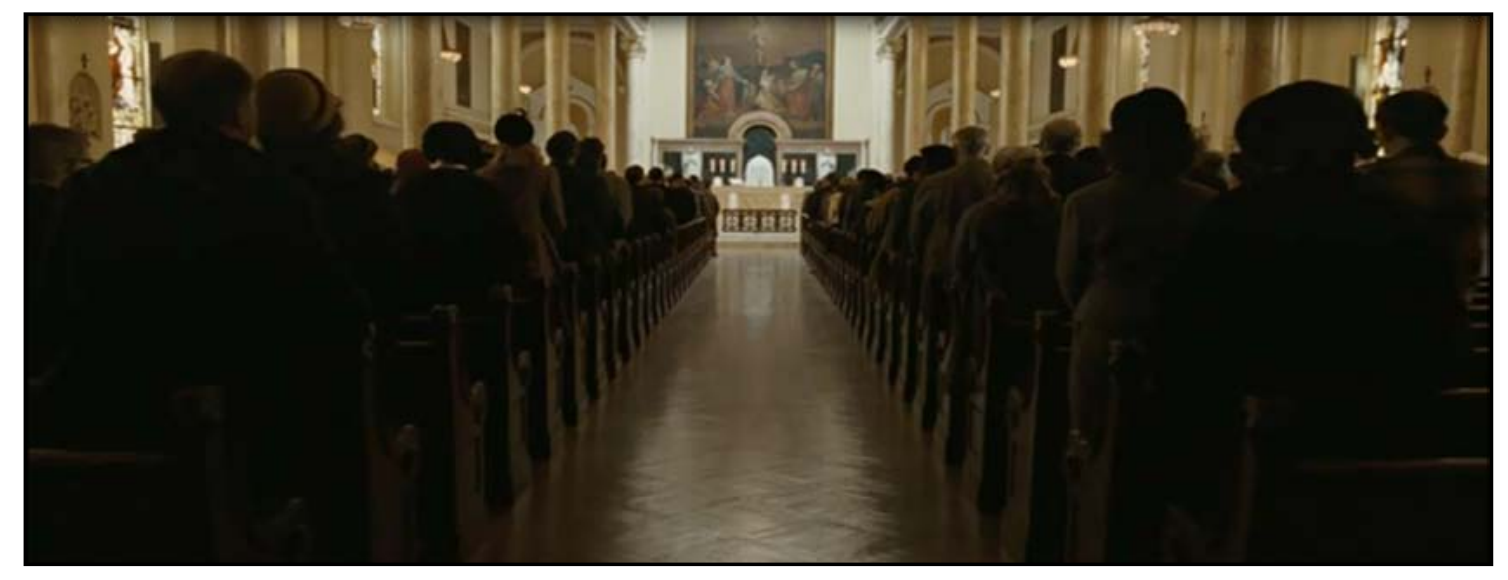

(Doubt, 2008) 


\subsubsection{Tensão: a verificação das hipóteses}

Não nos furtaremos de realizar, finalmente, a discussão concernente aos gradientes tensivos aderidos às modalidades CRER e SABER, que implica a avaliação das duas hipóteses que nos propusemos a verificar. Parece-nos produtivo, à luz das pertinentes considerações de Fontanille (1982), conceber graduações de tensão internas aos dois sistemas modais, além de mantermos as oscilações tensivas presentes na mudança de um a outro. Ou seja, tanto os percursos regressivos e progressivos como, por exemplo, da dúvida à adesão (no sistema do CRER), e da admissão à refutação (no sistema do SABER), quanto o percurso transgressivo (da dúvida à contestação), engendram oscilações tensivas importantes.

Dispondo da hipótese "o CRER tensiona e o SABER distensiona" (Lopes e Beividas, 2009, p. 447) e da contra-hipótese de que, em uma prática religiosa, na máxima crença o sujeito encontra a máxima distensão, voltamo-nos para a homologação dos sujeitos interpretativos do SABER e do CRER apresentada por Fontanille:

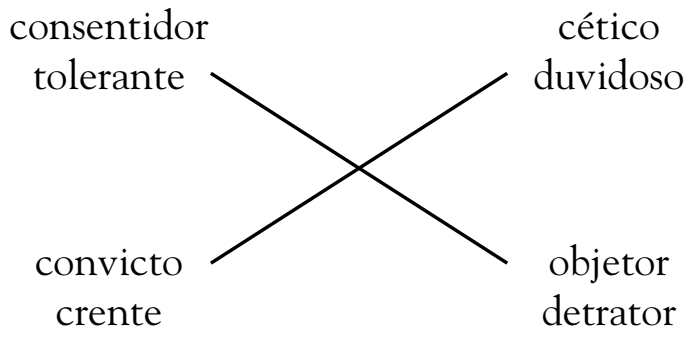

(Fontanille, 1982, p.25)

Uma primeira observação, de caráter intuitivo, é a de que tanto o sujeito convencido (sistema do SABER) quanto o crente (sistema do CRER) parecem se associar a baixas cifras tensivas (mais distensão) e à extensidade. Por outro lado, o objetor e o detrator denotam cifras tensivas altas e relacionam-se à intensidade. A dúvida, enquanto paixão e operação cognitiva fiduciária por nós analisada, certamente conta com cifra tensiva mais elevada do que a tolerância. A operação cognitiva própria do cético, contestar, segue a gradação tensiva de duvidar, mas o cético e o duvidoso parecem ser sujeitos em locais bastante distintos dentro de um gradiente tensivo. 
A modalidade como elemento delineador da identidade do sujeito, a variedade de sujeitos (o fanático, o ingênuo, o sábio, o generalista, o cético, o tolerante, etc.) engendrada em consequência da modalização de acordo com um CRER ou um SABER aliada, como veremos, às diferentes gradações tensivas (CRER e SABER átonos ou tônicos) e à quantidade de objetos visados pelo sujeito é um tema em que nos aprofundaremos ao longo do capítulo 3 . O aspecto para o qual gostaríamos de chamar atenção ao encarar os quadrados dos sujeitos interpretativos sugeridos por Fontanille alinha-se a nossos apontamentos intuitivos iniciais: o fato de que, tanto no sistema do CRER quanto no SABER, encontramos baixa e alta tensão.

A noção de gradientes tensivos aderidos aos quadrados semióticos concernentes às operações cognitivas a aos sujeitos interpretativos homologados não é encontrada originalmente no artigo de Fontanille, um texto produzido em 1982, momento em que as quantificações dos afetos ainda não constituíam pauta central para a teoria semiótica. Uma interpretação que parte da carga semântica de cada termo permite-nos, no entanto, representar em gráficos tensivos os sujeitos interpretativos de cada um dos sistemas de adequação cognitiva. Nesses gráficos, os sujeitos aparecem como resultantes de um valor no eixo da intensidade e outro no eixo da extensidade:

\section{SISTEMA DO CRER}

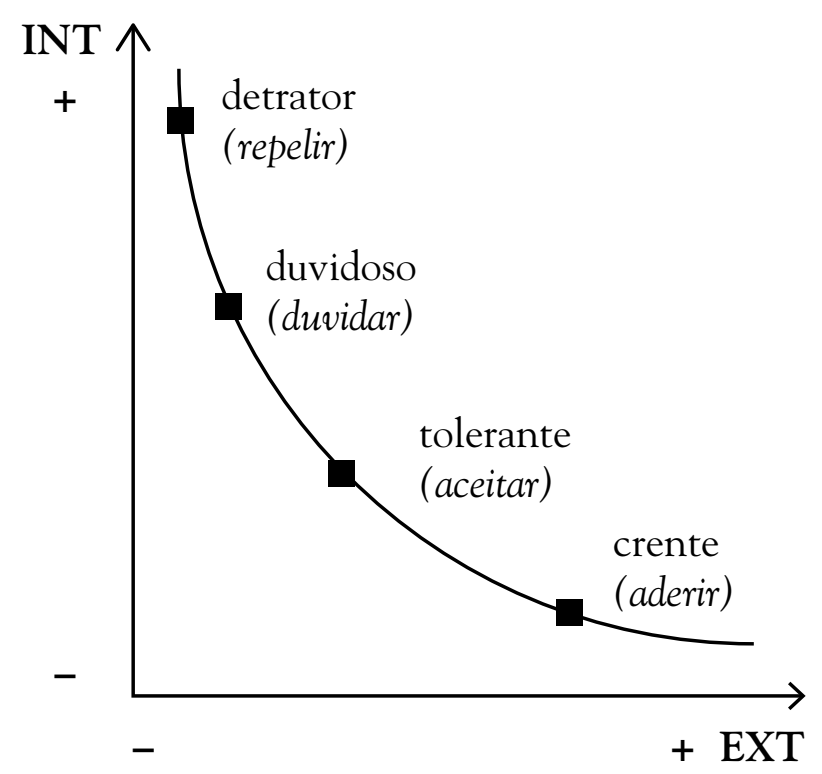




\section{SISTEMA DO SABER}

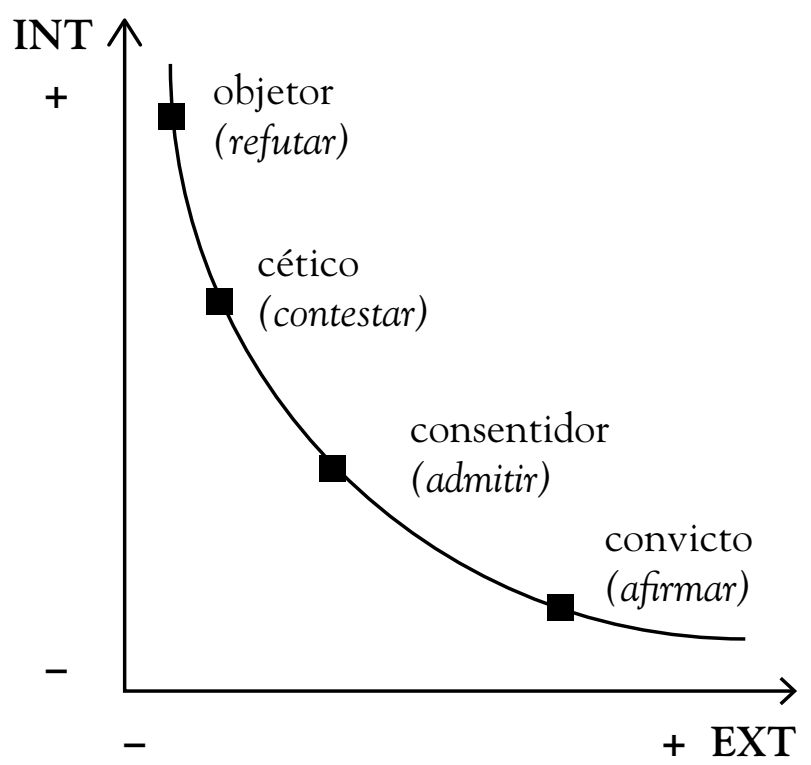

Estes são gráficos que não levam em consideração nem a foria aderida à modalidade (por exemplo: uma convicção tônica elevaria a cifra tensiva do sujeito convicto para além do convicto átono e até mesmo do consentidor átono) e nem a quantidade de objetos cognitivos visados pelo sujeito, uma caraterização tensiva mais detalhada que buscaremos empregar no capítulo seguinte. Por meio desses esquemas, procuramos apenas colocar os sujeitos interpretativos em relação, evidenciando, desse modo, a existência de variação tensiva interna aos dois sistemas. Tanto o sistema do CRER quanto o do SABER comportam altas e baixas cifras tensivas, ou seja, encontra-se um gradiente completo aderido a cada um dos dois universos de racionalidade, e não apenas tensões altas no CRER e tensões baixas no SABER, ou vice-versa.

Se retomarmos o percurso pressuposto pelo sermão de padre Flynn, da adesão à dúvida, podemos identificar um aumento de tensão. $\mathrm{O}$ sermão de Flynn, ao transmitir um SABER sobre a dúvida, visa a atenuar essa cifra tensiva e, idealmente, conduzir o sujeito de volta à adesão, onde a distensão é alta. Mas qual seria, então, a diferença entre uma baixa tensão que o sujeito experimenta no sistema do CRER e a (também) baixa tensão atingida dentro do sistema do SABER? Pensando ainda no artigo de Fontanille (1982), lembramos que uma característica distintiva entre esses dois sistemas é o fato de que, de acordo com o autor, o sistema do CRER é regido pelo dever-ser (que lhe confere caráter virtualizante), enquanto o do SABER, pelo poder-ser (caráter atualizante). 
Propomos, desse modo, uma aproximação do caráter atualizante do sistema do SABER e do virtualizante do sistema do CRER com os modos de presença do sujeito tal como definidos por Fontanille e Zilberberg em Tensão e Significação (2001, p. 123 - 151). Essa aproximação de modelos descritivos permitir-nos-ia observar uma importante característica distintiva entre o sujeito distenso pelo CRER em relação ao sujeito distenso pelo SABER: enquanto o sujeito distenso por um CRER está virtualizado, o sujeito distenso por um SABER está atualizado, portanto uma etapa à frente do sujeito do CRER em busca da liquidação de uma falta:

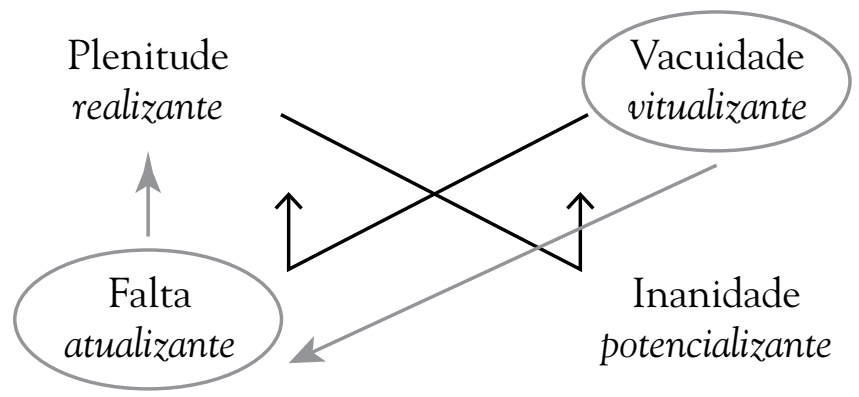

(Fontanille e Zilberberg, 2001, p. 134)

Desse modo, a maior ou menor tensão parece se relacionar antes com a natureza da operação cognitiva desempenhada pelo sujeito do que com o tipo de racionalidade ou universo axiológico em que ele se encontra (CRER ou SABER). Desse ponto de vista, a máxima crença, uma vez compreendida como a máxima adesão a uma ideologia religiosa, proporcionaria, sim, ao sujeito a máxima distensão, mas também a sua virtualização.

Olhando para nosso objeto de análise, o sermão do padre Flynn, podemos considerar verdadeira a epígrafe de autoria do poeta Bartolomeu Campos de Queirós: ao se agarrar à dúvida e nela perseverar, evitando o percurso transgressivo (ou o progressivo, que o levaria direto à repulsão), o sujeito se agarra à sua própria fé, mantém-se virtualizado (comandado por um dever-ser), e vislumbra como possível o percurso regressivo, que o realoca na adesão e lhe oferece conforto em termos de gradiente tensivo (atenuação da tensão).

A esta altura, já dispomos de resultados teóricos que nos permitem considerar verdadeiras ambas as hipóteses trazidas para análise e discussão: tanto o "CRER tensiona e o SABER distensiona" quanto "o SABER tensiona e o CRER distensiona" são arranjos modais e tensivos verídicos. Além disso, uma hipótese não exclui a outra, pois ambas encontram validação, descrição e explicação 
no âmbito da teoria semiótica da Escola de Paris - especialmente por esta conceber a dimensão cognitiva como um espaço essencialmente dinâmico, onde se encontram movimentos modais e tensivos, conversão fiduciária (Fontanille, 1982, p. 13), jogo elástico de forças (Lopes e Beividas, 2009, p. 446) e atualização e virtualização de sistemas de adequação cognitiva intercambiáveis (Fontanille, 1982 , p. 24).

O elemento central da contra-hipótese à proposta de Lopes e Beividas (2009), ou seja, o CRER como promotor da distensão na prática religiosa, encontra mapeamento semiótico ao longo de nossa análise do sermão do padre Flynn. De fato, o objetivo último do sermão do padre Flynn, conduzir o sujeito de volta à adesão, mantendo-o no sistema do CRER, aproxima-se do percurso modal trilhado por Damázio, personagem do conto de Rosa, ao final da narrativa. A diferença, no caso do jagunço, é que se trata de um sujeito que parte inicialmente da dúvida (sistema do CRER) sobre o significado de "famigerado" e, já no início do conto, completa o percurso transgressivo em direção à contestação (sistema do SABER) - que é, então, direcionada ao médico, narrador da ação.

A resposta do médico, de que famigerado significa "famoso", tem o efeito de uma manipulação que faz Damázio, então destinatário em relação ao personagem do médico (destinador competente detentor de um SABER), virtualizar seu sistema do SABER, atualizar seu sistema do CRER e, em percurso regressivo, rumar à adesão ao que lhe foi dito. Ali, Damázio encontra o conforto da distensão, como havíamos apontado, via CRER, mais especificamente via CRER-SABER, instituindose como sujeito, de acordo com nossa proposta de aproximação, virtualizado. Utilizando-se a estrutura sugerida por Fontanille (1982), seu percurso, partindo da dúvida e chegando à adesão, pode ser esquematizado da seguinte maneira:

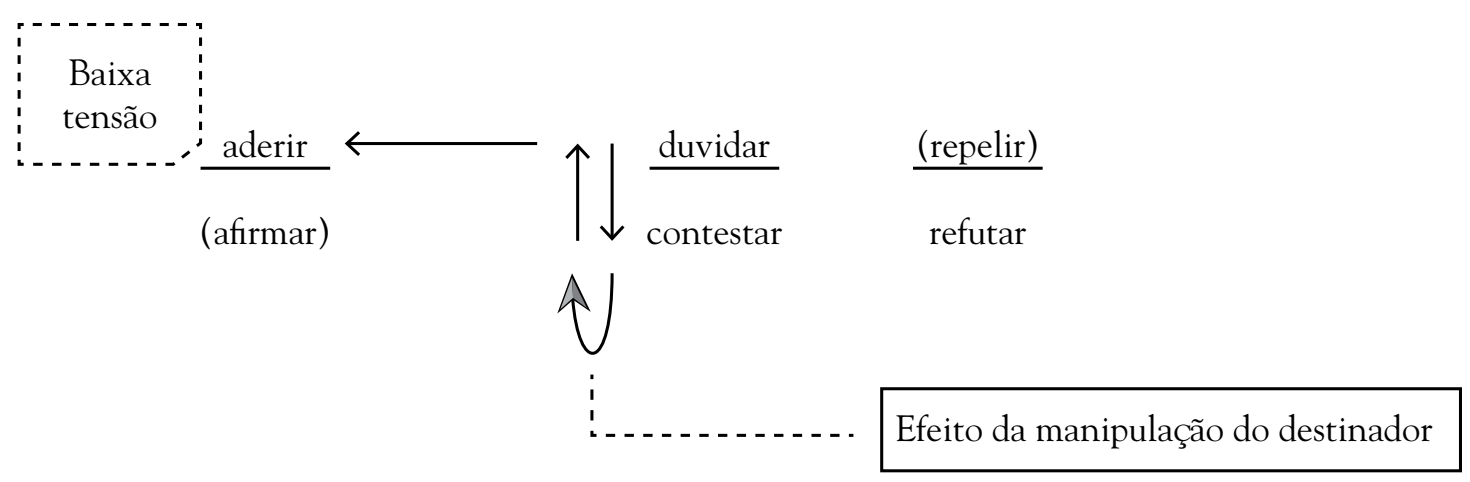


Ao pensarmos no percurso do médico/narrador, temos que este é, nos momentos iniciais da ação, também um sujeito da dúvida e, portanto, tem seu sistema do CRER atualizado e do SABER, virtualizado. À medida que a ação de desenrola, porém, esse sujeito adquire o status de destinador e manipula Damázio. De acordo com o modelo de Fontanille (1982), conforme a quantidade de dados observados, da ordem do SABER segundo Lopes e Beividas (2009), sobrepuja o apenas observado, da ordem do CRER, o médico virtualiza o sistema do CRER, atualiza seu sistema do SABER, onde contesta e refuta a possibilidade inicial de que o jagunço viera lhe ameaçar pessoalmente, e encontra a distensão via SABER, onde afirma algo sobre o objeto cognitivo que conhece: o significado da palavra "famigerado". De forma esquemática, seu percurso pode ser representado da seguinte forma:

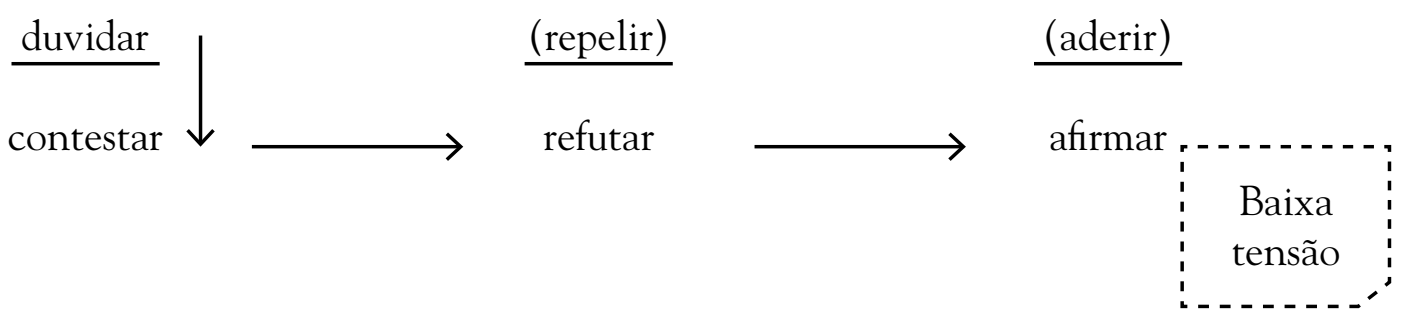

Retomando a noção encontrada em Zilberberg (2006, p. 142 - 143), de que o CRER privilegia os valores emissivos e conserva o objeto, enquanto o SABER acentua valores remissivos e destrói ou anula seus objetos, observamos que o sermão do padre Flynn, ao buscar reter o sujeito no sistema do CRER, objetiva também à conservação dos objetos, prática típica de uma devoção como a religiosa. Por outro lado, o percurso narrativo do médico e narrador de Famigerado parece nos mostrar um exemplar caso de sujeito que "mata a charada" que tem diante de si.

O SABER, como processo, para Zilberberg (2006, p. 144), anula o objeto por operar como uma resolução e reabsorção da clivagem conservadora imposta a ele pelo CRER. A conservação cognitiva, para o autor, consiste sempre em uma "clivagem do espaço: o não-saber (...) advém por divisão e compartimentação do espaço, enquanto o saber, é apenas a resolução, a reabsorção dessa clivagem" (2006, p. 144). A adivinhação de uma charada e a resolução de um enigma são figuras que Zilberberg emprega para exemplificar o momento em que o SABER incide sobre o, então conservado, objeto, cindindo-o, quebrando-o, anulando-o no momento em que o apreende. Consideramos que, no percurso narrativo do médico, em Famigerado, isso se dá na medida em que ele abandona o universo 
do CRER e atualiza o sistema do SABER, contesta e refuta seu objeto cognitivo (Fontanille, 1982); ou, à la Zilberberg (2006), resolve a clivagem impressa no objeto por um não-SABER, apreende-o e anula-o.

A noção de resolução das clivagens, que trabalha no sentido de dissipá-las, aproxima-se do que Fontanille (1987) define como a tensão para a reunificação e a tendência à homogeneização com que o SABER atua sobre os objetos:

Tudo se passa como se, em relação ao saber, uma tensão constante para a reunificação atravessasse o discurso e as práticas: tendência à acumulação, inclinação à homogeneização (...). Mesmo pontos de vista exclusivos que, por definição, fazem obstáculo a tal reunificação, podem ser ultrapassados, englobados, e seus saberes solipsistas reintegrados a um saber homogêneo. (Fontanille, 1987, p. 23)

Este excerto faz parte de uma argumentação mais extensa de Fontanille que busca contrastar os objetos do SABER, acumuláveis como entidades discretas e cujo aumento se dá por concatenação e justaposição, aos objetos tímicos, contínuos e não acumuláveis pelo fato de seu aumento ocorrer no nível da intensidade, por uma variação gradual e contínua (1987, p. 27).

É também a Fontanille que recorremos inicialmente para tecer algumas observações finais concernentes à estrutura da dimensão cognitiva. Considerando-se as definições teóricas que recebe, os modelos descritivos com os quais empreendemos nossa análise e os resultados daí decorrentes, tal dimensão mostra-se como um espaço essencialmente dinâmico, de avanços, recuos e travessias por parte do sujeito (percursos progressivos, regressivos e transgressivos de acordo com Fontanille (1982)) que, em eterna busca por seus objetos, no caso, a busca por conhecer ou saber algo sobre o mundo, ora conservaos e ora os destrói, em uma estrutura que, em sua totalidade, parece ser cíclica.

Afinal, recortamos uma pequena porção de percursos narrativos possíveis ao analisar, por exemplo, a trajetória do personagem Damázio, que duvida, mas depois adere, e do médico e narrador do conto, que duvida, contesta e refuta definitivamente um objeto, realocando-se no SABER. Mas, depois da adesão e da refutação de um objeto, o que segue? Fontanille destaca que a homologação 
dos dois sistemas, CRER e SABER, responsável por tornar possível o percurso transgressivo de um a outro, guarda tanto o risco quanto o mérito da estrutura: "A regra de virtualizações/atualizações recíprocas permite explicar (...) como determinado 'saber' que afirmamos se torna rapidamente um dogma ao qual ‘aderimos': é preciso apenas atravessar uma fronteira axiológica” (1982, p. 28).

A criação de dogmas, os saberes que se engessam em forma de crenças via adesão, têm, no entanto, retorno à dinamicidade garantido pela natureza da estrutura. O movimento interno nos sistemas de adequação cognitiva, e também de um a outro, é o princípio que enseja ainda a figura da "crise de fé" (da adesão à dúvida e, potencialmente, à refutação), por nós analisada, e a "vertigem da incerteza", exemplo provido por Fontanille (1982, p. 29 - 30). A "vertigem" consiste em uma estratégia persuasiva de Pascal para "reconduzir à fé" os homens "libertinos" que punham o rigor científico acima do poder de Deus. Como nos descreve Fontanille, a "vertigem da incerteza" conta com duas etapas: "a vertigem" em si, que leva o sujeito da afirmação à refutação (operações cognitivas ainda do sistema do SABER), e finalmente "a aposta", essencialmente um "ato de fé", que conduz o sujeito que teve seus SABERES arruinados à adesão no sistema do CRER. Os percursos podem ser observados a seguir:

a) "A vertigem":

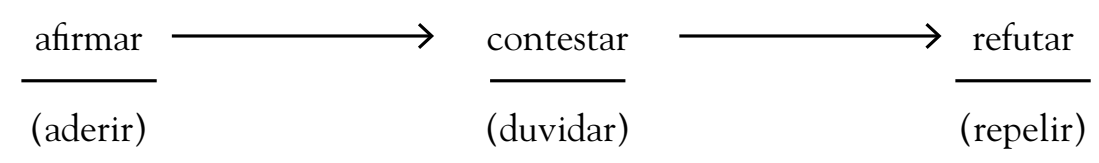

b) "A aposta":

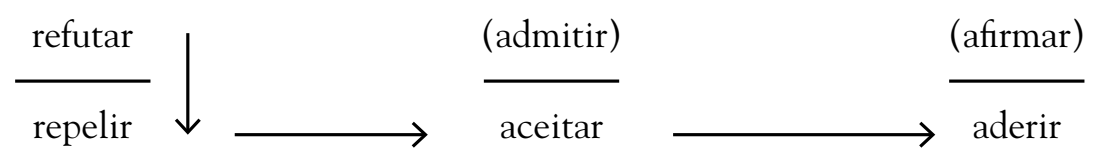

(Fontanille, 1982, p. 29 - 30) 
Outras representações gráficas que dão conta da dimensão cognitiva como um espaço de movimento ou, no mínimo, oscilação do sujeito, podem ser encontradas em Pottier (1983). O semioticista é responsável, como já observamos no capítulo 1, pela principal crítica ao quadrado epistêmico concebido por Greimas, apontando a ausência de contrariedade entre os termos "certeza" e "improbabilidade" e sugerindo que, em seu lugar, sejam utilizados "certo" e "excluído". Além disso, ele completa as posições, deixadas vazias por Greimas, do termo complexo com "decidível" e do termo neutro com "indecidível", chegando ao seguinte quadrado:

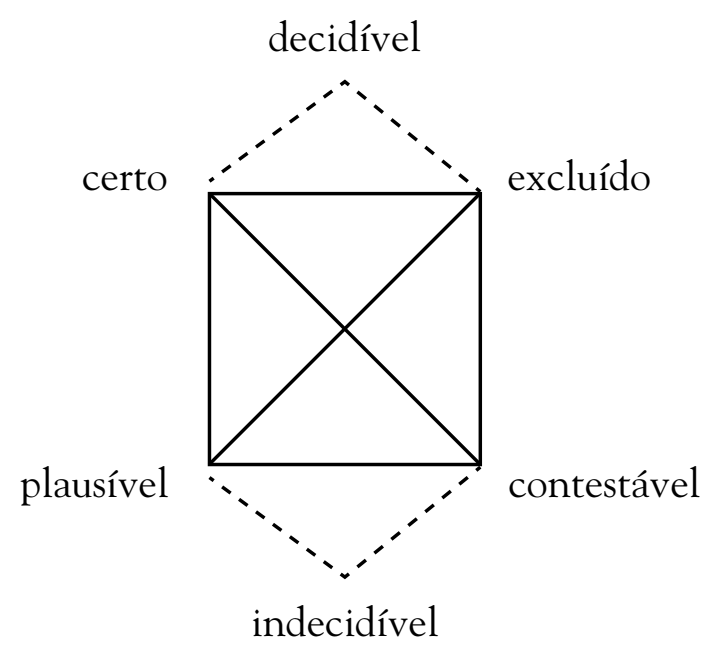

(Pottier, 1987, p. 208)

A partir dessa estruturação, no artigo "Le croire dans une perspective sémio-linguistique dynamique" (1983), Pottier extrai a estrutura a seguir:

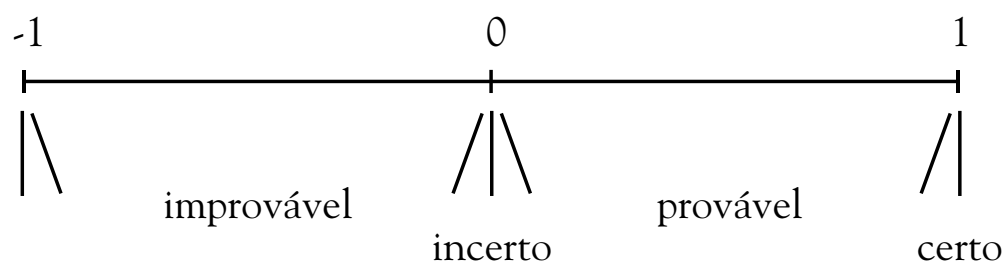

(Pottier, 1983, p. 272)

Em relação ao eixo conceitual $(-1 / 0 /+1)$, o autor afirma que, "se utilizado em cronoexperiência (pragmática) se torna um ciclo, com a alternância ordenada pelo tempo" (Pottier, 1983, p. 272): 


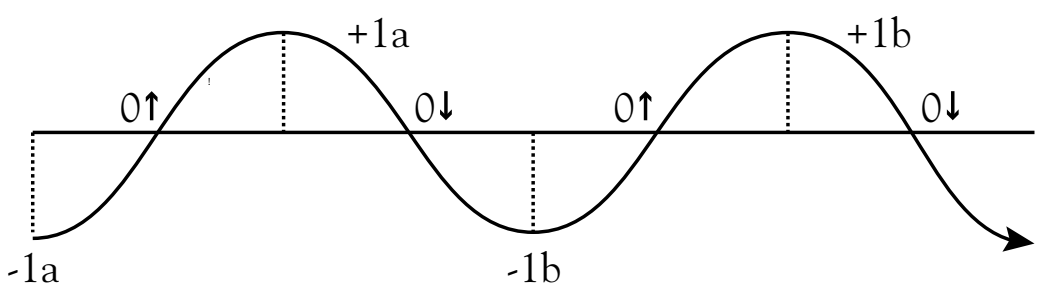

(Pottier, 1983, p. 272)

O arranjo em forma de onda sinusoidal é a estrutura que subjaz, então, a dois ciclos propostos por Pottier a partir do eixo conceitual que carrega termos do quadrado epistêmico concebido pelo autor: o ciclo do conhecimento/ memória e o ciclo da fé:

Ciclo do conhecimento/memória:

saber

aprender

ignorar

Ciclo da fé:

ter fé

esquecer

se lembrar

ter

esquecido

(Pottier, 1983, p. 272)

Os ciclos propostos dessa maneira por Pottier nos remetem ao delineamento de dois sistemas de adequação cognitiva de Fontanille (1982) e à definição das 
operações cognitivas próprias a eles aderidos. Em Pottier, o caráter cíclico dessas operações é evidenciado com maior ênfase, sobretudo pela estrutura sinusoidal que lhes ordena. De alguma forma, a passagem de um ciclo a outro (do conhecimento à fé, por exemplo), que em Fontanille encontra formulação teórica no conceito de percurso transgressivo, também é abordado por Pottier, que a comenta apenas laconicamente, mas a acompanha de uma representação gráfica e de uma decorrência teórica bastante pertinente para nosso estudo.

Segundo o autor, "O movimento que vai de $0 \mathrm{a}+1$ pode se exceder, seu limiar pode ser atravessado, e alcançamos então o 'conhecimento absoluto', aquele da fé" (Pottier, 1983, p. 273):

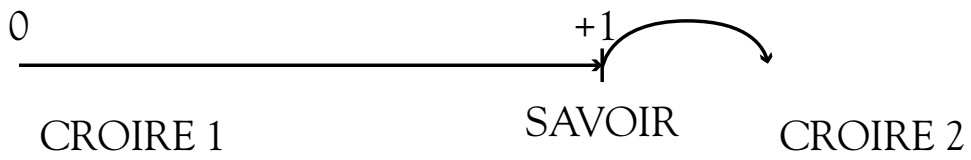

(Pottier, 1983, p. 273)

As decorrências do pontuado por Pottier, de que o conhecimento absoluto é, e apenas pode ser, aquele dado pela fé, é assunto que entra em discussão em nosso capítulo seguinte. Além disso, destacamos nesse modelo descritivo o intrincamento da memória no interior do processo de conhecimento, questão que abordaremos ao longo do capítulo 4.

Finalmente, a partir do tratamento teórico dado ao universo cognitivo como encontrado em Fontanille (1982), (1987) e (2007), Zilberberg (2006), Lopes e Beividas (2009) e Pottier (1983) e (1987), cujas reflexões nos serviram de base e ferramenta teórica para a análise a que nos propomos neste capítulo, destacamos a estruturação dessa dimensão como espaço que comporta movimento e oscilações da parte do sujeito, que pode estabelecer uma relação tanto dinâmica com seu objeto, eventualmente quebrando-o, quanto estática e conservadora, fixando-se a uma só operação cognitiva interna a um dos sistemas de adequação cognitiva (Fontanille, 1982) possíveis.

Ressaltamos também o contorno cíclico que o encadeamento dessas operações exibe e o fato de a passagem de um sistema a outro (do CRER ao SABER, e do SABER ao CRER) forçosamente imprimir efeitos de sentido importantes à narrativa. Esse movimento se afirma como princípio fundamental do fazer- 
interpretativo e da construção de conhecimento do sujeito em um mundo essencialmente discursivo. Para concluir, destacamos que a abordagem da pluralidade de operações próprias a cada sistema, ao lado das consequências que a análise semântica de tais operações tem em termos de gradientes tensivos, permitiu-nos identificar altas e baixas cifras tensivas tanto no CRER quanto no SABER, levando a cabo a análise das duas hipóteses iniciais postas em jogo e chegando à conclusão central deste capítulo: tanto no CRER quanto no SABER, há tensão e distensão. 


\section{Capítulo 3}
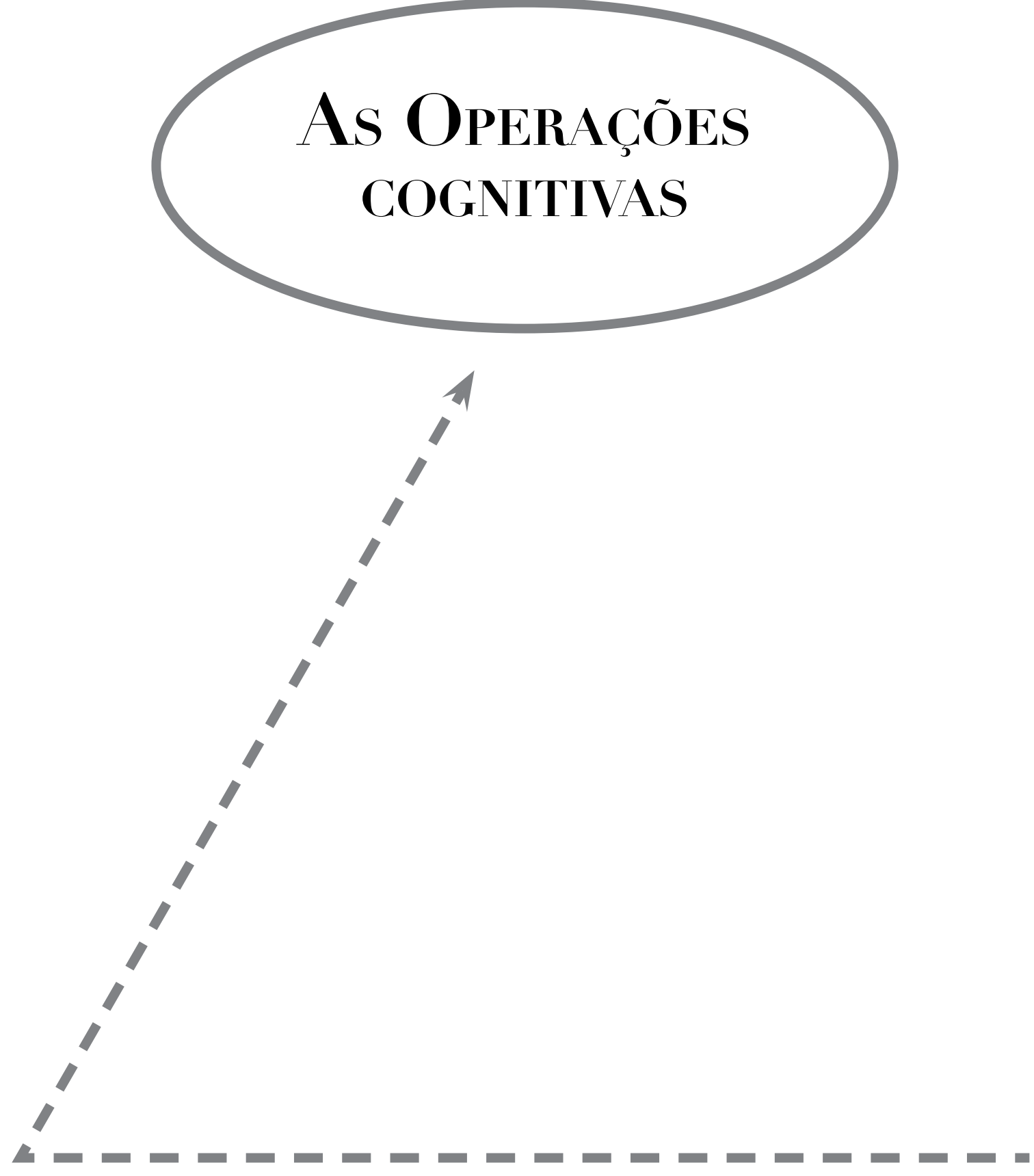


\subsection{Modalização, tensão e tipologia de sujeitos}

A estreita ligação entre modalização e delineamento da identidade do sujeito parece já estar expressa de antemão na teoria semiótica padrão, narrativa, visto que a configuração de um quadro modal para o sujeito constitui, de pronto, o relatório de sua competência para a ação. Mais especificamente em relação aos termos abordados nesta dissertação, Fontanille destaca que:

A distinção entre o saber e o crer é particularmente útil quando essas modalidades definem a identidade do sujeito. Tomemos como exemplo o sujeito que só visa objetos cognitivos no modo da intensidade máxima e da quantidade mínima: em se tratando de saberes, estaremos lidando com um erudito; em se tratando de crenças, teremos diante de nós um fanático. (2007, p. 228)

Nessa afirmação de Fontanille, encontramos uma abordagem teórica que já considera e trabalha com as decorrências da consistência tensiva que as modalizações assumem. Tal aproximação leva em conta que "as modalidades tornam-se valores modais: isso se dá em decorrência da projeção dos conteúdos modais sobre os gradientes da intensidade e da extensão, após uma coerção aplicada a esses gradientes sob a forma de um limiar" (Fontanille, 2007, p. 228).

Ao longo de nosso capítulo precedente, partimos de uma interpretação intuitiva e semântica das operações cognitivas e dos sujeitos interpretativos específicos aos sistemas do CRER e do SABER como definidos por Fontanille (1982) para estruturar uma escala comparativa das cifras tensivas aderidas a tais sujeitos e, consequentemente, às operações cognitivas correspondentes. O objetivo, então, era, ao colocar sujeitos de uma mesma modalidade (por exemplo, o SABER) lado a lado, observar a existência de diferentes cifras tensivas associadas a cada uma das operações cognitivas internas ao sistema (Fontanille define quatro operações próprias ao CRER e quatro ao SABER), constatação que nos permitiu identificar alta e baixa tensão tanto na modalização de acordo com um SABER quanto com um CRER.

Ao protocolo de análise que associa a modalização do sujeito a uma cifra 
tensiva decorrente do valor modal, adicionamos, de nossa parte, o caráter vitualizado do sistema do CRER e atualizado do sistema do SABER, como postula Fontanille (1982), e os relacionamos aos modos de presença do sujeito como definidos por Fontanille e Zilberberg (2001, p. 134) para diferenciar uma baixa tensão encontrada via CRER daquela atingida via SABER. Essa distinção parece ser aplicável a quaisquer cifras tensivas equivalentes porém engendradas por modalidades (CRER ou SABER) diferentes. Já Fontanille (2007) traz a noção de triagem para sua análise. Por meio dela, estabelece uma distinção relativa à valorização do sujeito ante a valorização do objeto, como observamos no seguinte trecho que retoma a distinção entre erudito e fanático:

O erudito só se define na relação que ele estabelece entre objetos cognitivos: o forte coeficiente de triagem que ele lhe (sic) impõe não tem incidência alguma na posição que ele adota a seu respeito, e menos ainda em relação a sua posição perante outrem - ele só exclui para conhecer mais. Em contrapartida, o fanático compromete, em suas restrições, sua relação com os outros universos de assunção e, consequentemente, com os outros sujeitos que os assumem: o forte coeficiente de triagem aplica-se, assim, tanto aos sujeitos cognitivos quanto aos objetos cognitivos - ele exclui, justamente com os objetos rechaçados, os sujeitos que os assumem. Deve-se notar, por sinal, que a valorização do objeto cognitivo acarreta também uma valorização ou desvalorização do sujeito. (Fontanille, 2007, p. 228)

Outro exemplo de complexificação do protocolo de análise de base, supracitado, pode ser encontrado em "Algumas considerações sobre o crer e o saber" (Cruz, 2008), artigo em que o autor nos apresenta um estudo semiótico sobre a paixão da ingenuidade, caracterizada, segundo ele, por um arranjo modal onde CRER e SABER se encontram em relação de oposição:

(...) o ingênuo não é apenas aquele que está em disjunção com um saber, mas que apresenta um crer excessivo e, por essa razão, reprovável. A ingenuidade nasce, portanto, de uma combinação especial das modalidades do crer e do saber: a primeira, demasiada; a segunda, escassa. (Cruz, 2008, p. 2) 
Sua abordagem teórica acerca do sujeito ingênuo inclui, além de definições dicionarizadas para ingenuidade, ingênuo, fanatismo (paixão a que a ingenuidade é contrastada) e fé recolhidas em Le Petit Robert, International Dictionary of English e Houaiss, a noção de campo de presença como espaço em que o sujeito relacionase com seus objetos cognitivos e a análise da tonicidade, em seu par opositivo átono/tônico, aderida à modalização. A partir desse gesto metodológico, Cruz logra diferenciar o ingênuo, aquele que tem CRER extenso e átono, do fanático, cujo CRER é intenso e tônico:

(...) a propensão do ingênuo para a crença indica que esse sujeito possui um campo de presença amplo, que lhe possibilita relacionarse com uma extensa gama de objetos de saber. Embora não se possa afirmar de forma peremptória, é provável que a relação do ingênuo com sua crença tenda a ser átona, pois uma ligação tônica talvez dificultasse sua adesão a outras crenças. (...)

O fanático, diferentemente do ingênuo, é detentor de um querer também intenso e excessivo, o qual é responsável por sua paixão, pelo seu zelo, por seu apego às convicções. A convergência e a intensidade das modalidades do crer e do querer são responsáveis pela tonicidade que caracteriza as relações do fanático com seu objeto (...).

Enfim, embora tanto o crer do fanático quanto o do ingênuo sejam excessivos, o excesso se deve, no primeiro caso, à intensidade e, no segundo, à extensidade. $\mathrm{O}$ fanático tem um crer intenso que reduz seu campo de presença, o torna pouco extenso e faz com que raros sejam os objetos de saber visados e poucos aqueles nos quais ele crê. Por outro lado, o crer do ingênuo é extenso, por isso ele tende a capturar e apreender tudo que lhe dizem (...). Em contrapartida, sua ligação é átona, pouco intensa. (Cruz, 2008, p. 3)

As operações de triagem e mistura associadas às modalidades também são verificadas, assim como encontramos na análise de Fontanille (2007, p. 227 229), e contribuem para a distinção entre a ingenuidade, ligada à mistura, e o fanatismo, onde se destacam as operações de triagem (Cruz, 2008, p. 4). Ritmo e andamento da relação entre o sujeito e seus objetos são outros dois aspectos próprios da abordagem tensiva dos textos que aparecem no estudo de Cruz e contribuem para a caracterização da paixão e, consequentemente, do sujeito sob análise: o autor aponta, para o sujeito ingênuo, um ritmo e andamento mais veloz com os objetos, visto que seu saber átono "funcionaria como um inibidor 
da tensão de sua relação com o objeto e tornaria suas crenças voláteis, efêmeras: da mesma maneira que as adquiriu, pode perdê-las" (Cruz, 2008, p. 3).

A partir também de uma distinção relativa à modalização do sujeito, aqui, segundo um SABER, que é classemática e instaura uma distância hierárquica entre um SABER "semiótico", de nível "n", e um SABER "meta-semiótico", que pode ter nível "n+1" ou "n-1", Fontanille (1987, p. 49) realiza a diferenciação entre o sujeito informado e o sujeito culto. Visto que os saberes de nível n, para Fontanille (1987, p. 32 - 33), são aqueles que estão no mesmo nível de seu objeto e permitem uma “apreensão do conteúdo de sentido", enquanto os saberes meta-semióticos têm nível superior ou inferior em relação a seus objetos, e se referem à construção $(\mathbf{n}+1)$ ou à análise $(\mathbf{n}-1)$ destes, o autor postula que:

O sujeito "informado" dispõe de um saber de nível "n", o sujeito "culto" pode ser dotado seja de um hiper-saber ${ }^{25}$ de nível " $n+1$ ", seja de um hiper-saber de nível "n-1"; no primeiro caso, a "cultura" é um modo de organização discursiva e figurativa da informação: é uma modalidade "contensiva"; no segundo caso, a "cultura" é uma relação de saberes informativos com camadas semânticas mais profundas, por exemplo com a ideologia ou as axiologias próprias a um grupo. (Fontanille, 1987, p. 49)

Observamos desse modo que a metodologia de abordagem, descrição e explicação da identidade de sujeitos em íntima relação com sua modalização e operações modais correlatas mostra-se pertinente já no nível da gramática modal, cuja ênfase está na perspectiva categórica. Ela ganha em alcance e profundidade, como vemos nos estudos mais recentes, com a análise tanto das gradações tensivas projetadas nos eixos da intensidade e da extensidade por um valor modal como do ritmo e andamento que se instauram entre o sujeito e seus objetos, no caso de nosso estudo, cognitivos.

É apropriando-nos de tais ferramentas que nos lançamos à análise de um breve poema, apresentado a seguir, em que, a partir de arranjos modais distintos,

25 A noção de "hiper-saber" é reservada por Fontanille aos saberes meta-semióticos, saber-ser e saber-fazer, nos quais o fazer ou o ser que eles modalizam dependem de um programa de natureza cognitiva: "os hiper-saberes são, portanto, os operadores modais de nível ' $n+1$ ' ou 'n-1' que afetam enunciados em que o objeto de valor é um saber, seja no nível do enunciado, seja no nível da enunciação" (Fontanille, 1987, p. 49). 
podemos depreender a identidade de três tipos de sujeitos. Nosso objetivo é endossar a relevância teórica da vinculação das noções de modalização e tensão à construção identitária do sujeito e explicitar o fato de que a teoria semiótica logra descrever e explicar tanto o que une quanto o que separa sujeitos cognitivos, à primeira vista, tão apartados semanticamente quanto, por exemplo, o ingênuo e o fanático.

De fato, ela demonstra que tais sujeitos cognitivos são semioticamente regidos por princípios de funcionamento idênticos (modalizam-se segundo um CRER, que se torna um valor modal com a projeção de conteúdos sobre gradientes da intensidade e da extensidade, realizam operações cognitivas próprias a esse sistema de adequação, estabelecem uma relação com seu objeto que é dotada de ritmo e andamento, etc.) e que sua distinção reside, no exemplo citado, em uma diferença de extensão e tonicidade, como apontado por Cruz (2008). Com esse exemplo, evidencia-se a importância da quantificação dos afetos, que se constitui como tema de interesse e tarefa teórica a ser encarada pela semiótica ao fim dos anos 80, para o delineamento da identidade do sujeito e de suas paixões.

Dentre os estudos que formam nosso embasamento teórico, apresentado ao longo do capítulo 1, abordagens mais acentuadamente categóricas ou tensivas encontram-se cronologicamente distribuídas. Predominantemente categóricas, as articulações conceituais concernentes ao universo do CRER e do SABER como postuladas por Fontanille (1982) permitem-nos destrinchar em nível narrativo uma numerosa tipologia de paixões, como a crise de fé, a cegueira pelo fanatismo, o cinismo do cético, a desilusão com a ciência, e seus respectivos sujeitos imbuídos em narrativas: o tolerante, o desconfiado, o cético, o crente, o questionador etc., esquematizados da seguinte maneira de acordo com a homologação dos universos de racionalidade proposta pelo autor:

(I) Os sujeitos interpretativos:

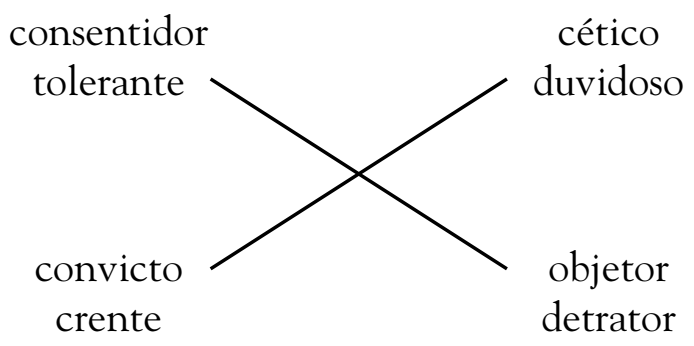

(Fontanille, 1982, p. 25) 
Como já pudemos observar anteriormente, Fontanille concebe diferentes tipos de sujeitos interpretativos que se distinguem pelo universo axiológico em que se encontram (CRER ou SABER), pelo fato de estarem atualizados (no universo do SABER) ou virtualizados (no universo do CRER) e pelas diferentes operações cognitivas que executam (modo de relacionamento com o objeto cognitivo). A noção de modos de presença que unimos a tal arranjo teórico de Fontanille, autor que assume como significativa para o fazer epistêmico a distinção entre sujeito atualizado vs. virtualizado, postula que o "eu" semiótico habita um espaço tensivo onde "as modulações da presença e da ausência fornecem, em suma, a primeira modalização das relações entre o sujeito e o objeto tensivos, a modalização existencial", na qual "a plenitude é realizante, a falta é atualizante, a vacuidade é virtualizante e a inanidade é potencializante" (Fontanille e Zilberberg, 2001, p. 131). Esquematicamente, temos:

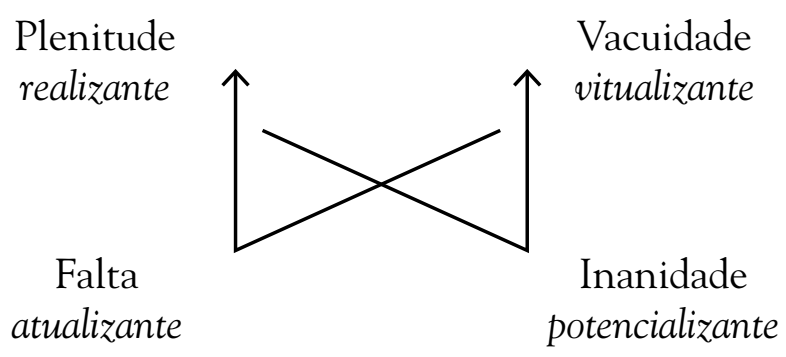

(Fontanille e Zilberberg, 2001, p. 134)

As reflexões encontradas em Tensão e significação (2001) e em Razão e poética do sentido (Zilberberg, 2006) estruturam nossa abordagem de elementos tensivos como a tonicidade, o ritmo e o andamento da relação entre sujeito e objeto e sustentam também a própria associação entre uma paixão e uma cifra tensiva. De fato, Zilberberg concebe as operações juntivas como resultantes de modulações de velocidade e define o andamento como germe fundamental da produção de significação. E, uma vez que a velocidade determina qual é a experiência do sujeito no percurso narrativo, a abordagem do texto passa a proceder a análises, como empreenderemos aqui, ancoradas nos eixos da intensidade e da extensidade, onde espaço e tempo (na extensidade) são regidos pelo andamento e pela tonicidade (na intensidade).

Tal esquematização e arranjo tensivos nos permitem pensar em cifras tensivas associadas a uma paixão ou modalidade. As cifras tensivas, constituídas por um valor de intensidade e outro de extensidade, substituíram as equações de 
Greimas para a análise das paixões, que operavam sob a lógica modal juntiva. A reformulação tensiva e posterior manipulação e desenvolvimento do paradigma zilberbergiano também possibilitam a concepção de um percurso narrativo como ascendência $(++)$ ou descendência $(--)$.

Essas noções teóricas se mostram pertinentes para a análise ora proposta, que toma como corpus um poema que põe em jogo as modalidades CRER e SABER, explora-as tematicamente e extrai alguns efeitos de sentido de sua oposição, exacerbação e atenuação, bem como do sujeito do SABER em plenitude, vacuidade e falta. 


\subsection{Crer-SABER, SABER mal e SABER pouco - análise de três operações cognitivas em um poema}

\subsubsection{Corpus}

Nosso corpus de análise é composto por um pequeno poema de autoria desconhecida declamado por Antônio Abujamra ao final do programa de TV Provocações ${ }^{26}$ do dia 26 de julho de $2011^{27}$ :

Há uma diferença muito grande entre saber e acreditar que se sabe.

Saber é ciência, acreditar que se sabe é ignorância.

Mas cuidado: saber mal não é ciência.

Saber mal pode ser muito pior do que ignorar.

Na verdade, sabe-se somente quando se sabe pouco.

Pois, com o saber, cresce a dúvida,

que é preciso idolatrar sempre.

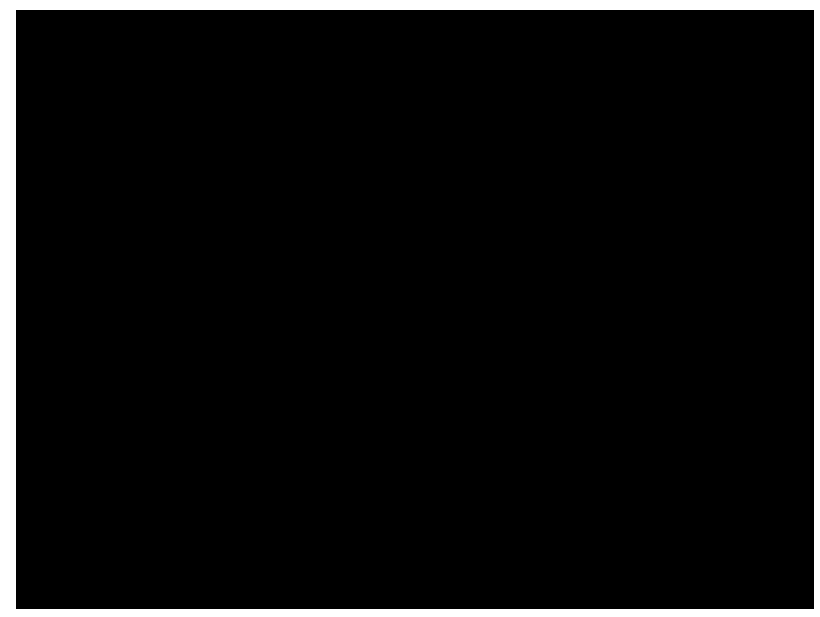

$26 \mathrm{O}$ programa Provocações é veiculado pela TV Cultura todas as terças às $23 \mathrm{~h}$. A atração estreou em 6 de agosto de 2000 e é apresentada por Antônio Abujamra, que, depois de realizar uma entrevista com o convidado da semana, encerra o programa recitando textos de autores consagrados da literatura, de autores estreantes ou de autoria desconhecida, caso do texto em análise. Conforme a produção do programa informou e pudemos confirmar com pesquisa de nossa parte, além de não ter um autor, o poema também não possui um título.

27 Recomenda-se que a leitura de Abujamra seja assistida. Ela pode ser acessada em: http:// www.youtube.com/watch? $=$ =bhL-HyLvCj8\&feature=feedu_more $($ acesso em 1\%/8/2013) 
O texto acima é uma transcrição baseada no áudio da leitura realizada por Abujamra. Portanto, aspectos formais do plano da expressão, como a métrica e o encadeamento dos versos, não serão levados em consideração em nossa análise. O que privilegiamos aqui é a construção discursiva de diferentes tipos de operações cognitivas e a caracterização semiótica de seus sujeitos correlatos.

\subsection{2 "uma diferença muito grande"}

O poema começa estabelecendo uma distinção entre "saber" e "acreditar que se sabe". A "diferença muito grande" que caracteriza discursivamente a natureza do liame entre os dois tipos de "saber" em questão equivale, em nossa visada semiótica, à relação de oposição em nível profundo entre SABER ("saber") e CRER ("acreditar que se sabe”). Tal oposição subjaz a muitas outras construções discursivas proverbiais e literárias.

É este o caso do provérbio citado por Greimas no início de "Le savoir et le croire: un seul univers cognitif", capítulo de Du Sens II (1983): "Nous savons tous que nous mourrons, mais nous ne le croyons pas"28 (Greimas, 1983, p. 116); e também do verso shakespeariano "When my love swears that she is made of truth, I do believe her, though I know she lies"29 (Shakespeare, 2005, p. 657), retomado por Alexandrescu em seu artigo Saying and (Dis)believing (1983, p. 16). Ambas construções já foram apresentadas na Introdução desta dissertação justamente por ilustrarem o funcionamento dos verbos crer e saber nas línguas naturais: ao mesmo tempo em que têm a propriedade de se sobrepor sem se confundir, eles chegam a de fato se opor.

A partir de tais exemplos, podemos observar que a relação de oposição contraída pelo CRER e pelo SABER, malgrado possa ser caracterizada como definidora de "uma diferença muito grande" entre uma coisa e outra, em vez de lograr distinguir os dois termos, afastando-os, termina por aproximá-los em imaginário humano, construído pela linguagem.

28Em tradução livre: Todos sabemos que vamos morrer, mas não acreditamos nisso.

29 Em tradução livre: Quando minha amada jura que é feita de verdade, eu realmente acredito nela, apesar de saber que ela mente. 
No segundo verso, "Saber é ciência, acreditar que se sabe é ignorância", continua-se explorando os efeitos de sentido que a oposição profunda CRER vs. SABER é capaz de render em nível discursivo. A associação do termo SABER à ciência e CRER à ignorância acaba por alocar o SABER na dêixis eufórica, enquanto a disforia fica reservada ao CRER. É preciso atentar para o fato de que em "Saber mal pode ser muito pior do que ignorar" a figura da ignorância parece se referir efetivamente ao sujeito que ignora um objeto por ele estar fora do seu campo de presença. Não há, portanto, presença sensível. Não existe percepção do fenômeno por parte do sujeito e, consequentemente, ele não se modaliza (seja de acordo com um CRER ou um SABER) em relação a ele. Sumariamente, não existe relação.

Algo diverso, porém, pode ser depreendido da figura da ignorância no verso "Saber é ciência, acreditar que se sabe é ignorância". Uma vez associada ao CRER, a ignorância, aqui, pressupõe modalização e, portanto, percepção e relação. Se pensarmos em termos de tipologias de sujeitos interpretativos, o CRERSABER é uma operação cognitiva comum tanto ao ingênuo quanto ao fanático, distinguidos por Cruz (2008), como vimos, em termos tensivos. Já de acordo com Fontanille (1982), ambos são sujeitos virtualizados que realizam operações fiduciárias dentro do universo de racionalidade do CRER, dominados, portanto, por um dever-ser. Enquanto sujeitos interpretativos, ambos se caracterizam como "crentes":

(I) Os sujeitos interpretativos:

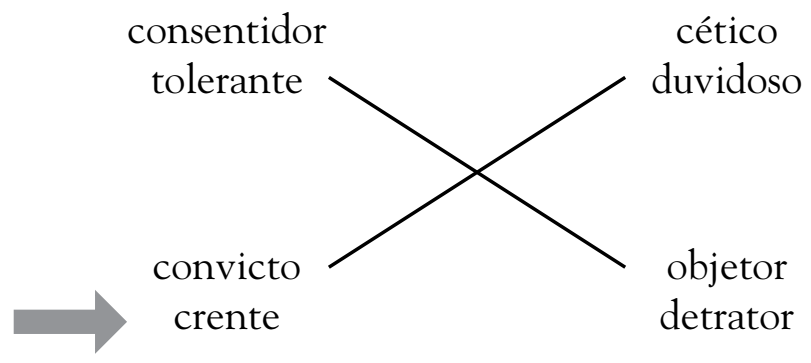

(Fontanille, 1982, p. 25) 
E sua operação cognitiva predominante seria a adesão:

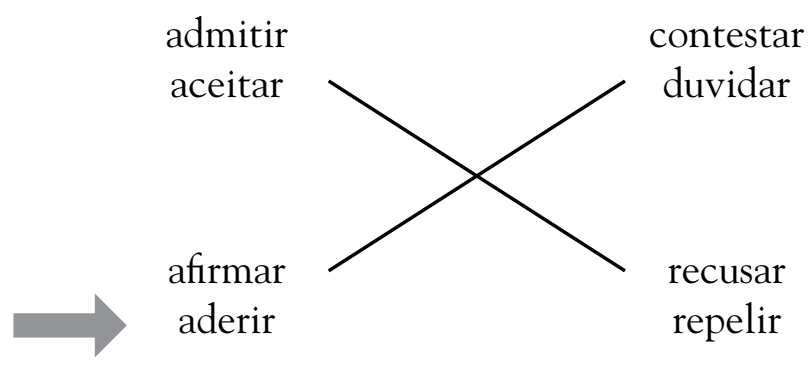

(Fontanille, 1982, p. 25)

Voltando-nos às relações de sentido discursivamente construídas pelo poema em análise, o sujeito que crê saber ("acreditar que se sabe"), seja ele um ingênuo, um fanático ou, enfim, um crente, é um "ignorante". Não pelo fato de não ter percepção do fenômeno, mas por seu fazer interpretativo ser, de alguma maneira, deficitário. $\mathrm{O}$ mau funcionamento do fazer interpretativo é uma característica que o "crente" parece compartilhar com o sujeito que "sabe mal" (a ser analisado no tópico seguinte). Entretanto, chamamos a atenção para uma distinção: enquanto o sujeito que "sabe mal” detém um fazer interpretativo precário por contar com uma modalização, como veremos, atenuada e qualitativamente insuficiente, em que a relação estabelecida entre o sujeito e objeto tem ritmo e andamento rápidos, aquele que crê-saber parece ser refém de um fazer interpretativo sempre enviesado, para o qual a variação nas gradações (de ritmo, andamento, tonicidade) associadas a essa modalidade não representa seu aperfeiçoamento ou melhora.

De fato, a disforia asssociada ao CRER parece definir uma baixa qualidade para os objetos cognitivos visados pelo sujeito, mesmo que este se modalize segundo um CRER intenso e tônico, e estabeleça com os objetos uma relação de ritmo e andamento lentos, como é o caso, por exemplo, do fanático. De acordo com o observado no poema, pouco importa se temos um CRER intenso ou extenso, uma relação entre sujeito e objeto átona ou tônica, de andamento lento ou veloz: o sujeito que crê não conhece seus objetos de verdade, operação cognitiva "bem-sucedida" que parece estar reservada ao âmbito da ciência, onde o sujeito modaliza-se de acordo com um SABER.

Em certa medida, o estabelecimento dessa oposição põe em prática a dicotomia desaconselhada e apontada como falsa por Greimas (1983, p. 116) para os termos CRER e SABER. Revestida de um sentido maniqueísta, o que temos 
aqui é uma oposição polarizada entre CRER e SABER que concebe a ciência como uma prática rigorosamente isenta de crenças, noção que debateremos mais detidamente no item 3.3 "O CRER na ciência”.

Voltando à análise do poema, temos que quem crê-SABER não sabe, mas como se distingue de outro tipo de sujeito: o que sabe mal?

\subsubsection{Saber mal}

Se o "saber mal não é ciência”, em que ele se difere da crença? O advérbio "mal" que qualifica a modalização aponta a precariedade do fazer-interpretativo do sujeito sobre os objetos em seu campo de presença. Temos aqui uma modalidade atenuada $(+-)$, que engendra um sujeito da falta. Como hipótese ainda a ser retomada e verificada, e influenciados pela definição de Fontanille (1982) de que o SABER é atualizante e o CRER é virtualizante, propomos alocar o sujeito da crença (aquele que "acredita que sabe") na vacuidade (virtualizante) e o sujeito que "sabe mal" na falta (atualizante):

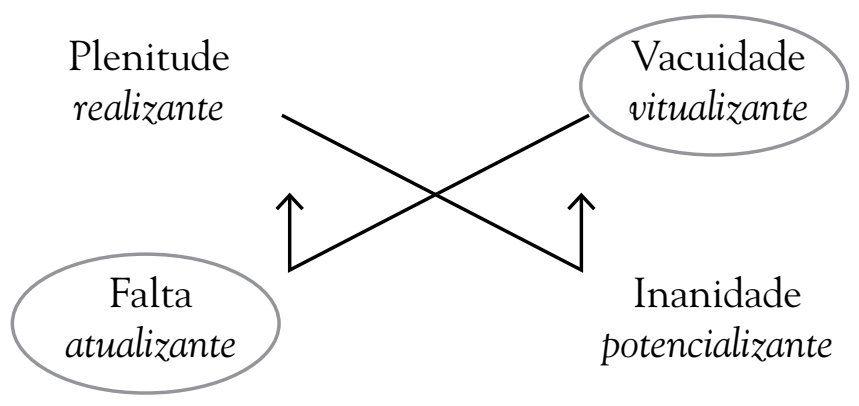

(Fontanille e Zilberberg, 2001, p. 134)

Os objetos do "saber mal" recebem do sujeito uma visada rápida e difusa, talvez por existirem em número demasiado, em um campo de presença amplo em excesso. De fato, o "saber mal" no poema opõe-se ao "saber pouco", que implica poucos objetos cognitivos no campo de presença do sujeito. Se o CRER extenso e átono é definido como aquele próprio do ingênuo, como proposto por Cruz (2008), encontramos no "saber mal" a configuração tensiva do SABER extenso e átono, que pode ser concebida como a do sujeito equivocado. Uma 
diferença de tonicidade nos parece ser responsável pela distinção do equivocado em relação a outro sujeito do SABER, o generalista, que defendemos ter também muitos objetos em seu campo de presença e um SABER extenso, porém tônico.

O caráter precário associado ao fazer interpretativo do sujeito que "sabe mal" diferencia-se daquele apontado para o que "crê SABER" por ser reversível: ao diminuir a quantidade de objetos cognitivos visados, o sujeito que "sabe mal" torna-se mais competente para apreendê-los. De fato, se o número de objetos for reduzido, se o ritmo e andamento de sua relação com eles forem desacelerados e se a tonicidade for alterada de átona para tônica, aquele que "sabe mal", como propomos aqui, o equivocado, assume a identidade modal e tensiva que concebemos para outro sujeito do SABER, o especialista.

\subsubsection{Saber pouco}

O saber pouco, euforicamente valorado na narrativa, implica alta densidade de presença do sujeito em relação a seus objetos cognitivos, que têm número reduzido. Temos aqui um SABER intenso (em campo de presença reduzido) e tônico. O sujeito, por ser aquele que compreende os objetos cognitivos situados em seu campo de presença, é entendido, aqui, como o sujeito da plenitude. Narrativamente, o poema nos apresenta o CRER-SABER, o SABER mal e o SABER pouco, obedecendo, assim, ao percurso:

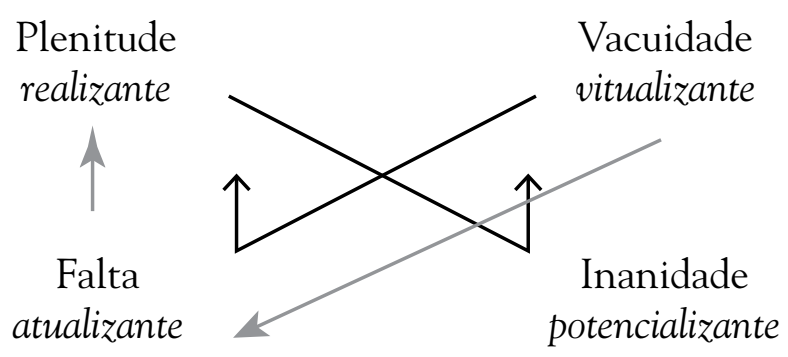

(Fontanille e Zilberberg, 2001, p. 134) 
Porém, o saber, que ascende à plenitude ao configurar-se como "saber pouco" encontra-se em lógica implicativa com a dúvida: quanto mais saber, mais dúvida, como podemos observar no penúltimo verso "Pois, com o saber, cresce a dúvida". A dúvida, no poema, é algo, no entanto, "que é preciso idolatrar sempre". Essa categoria modal configura, assim, um elemento que não atrapalha a operação cognitiva do fazer-interpretativo, mas que, pelo contrário, a auxilia. De fato, o papel salutar da dúvida na construção do conhecimento vem a equilibrar um aspecto da cognição humana ressaltado em Fontanille (1982, p. 28): "a regra de virtualizações/atualizações recíprocas permite explicar também que determinado 'saber' que 'afirmamos' rapidamente se torna um dogma ao qual 'aderimos"'.

É preciso lembrar que Fontanille delimita “dois universos de racionalidade" (Fontanille, 1982, p. 11), um concernente ao CRER e o outro ao SABER, que pressupõem juntos "um mesmo sujeito cognitivo, suscetível alternadamente ao CRER e ao SABER" (Fontanille, 1982, p. 24). A adequação (ou fazer-interpretativo) é uma operação cognitiva dinâmica, em que “crenças' e 'saberes' se virtualizam uns aos outros. Quando as operações de adequação são atualizadas em um sistema, elas são virtualizadas no outro" (Fontanille, 1982, p. 27). A passagem de um sistema a outro se dá por um percurso transgressivo que, em nosso poema, é desengatilhado pela dúvida. Se a dúvida incidir sobre o sistema do SABER, desempenhando seu papel salutar de impedir que aquilo que afirmamos (de acordo com um SABER) rapidamente se transforme num dogma ao qual aderimos (virtualização do sistema do SABER para atualização do CRER), esquematicamente temos: 


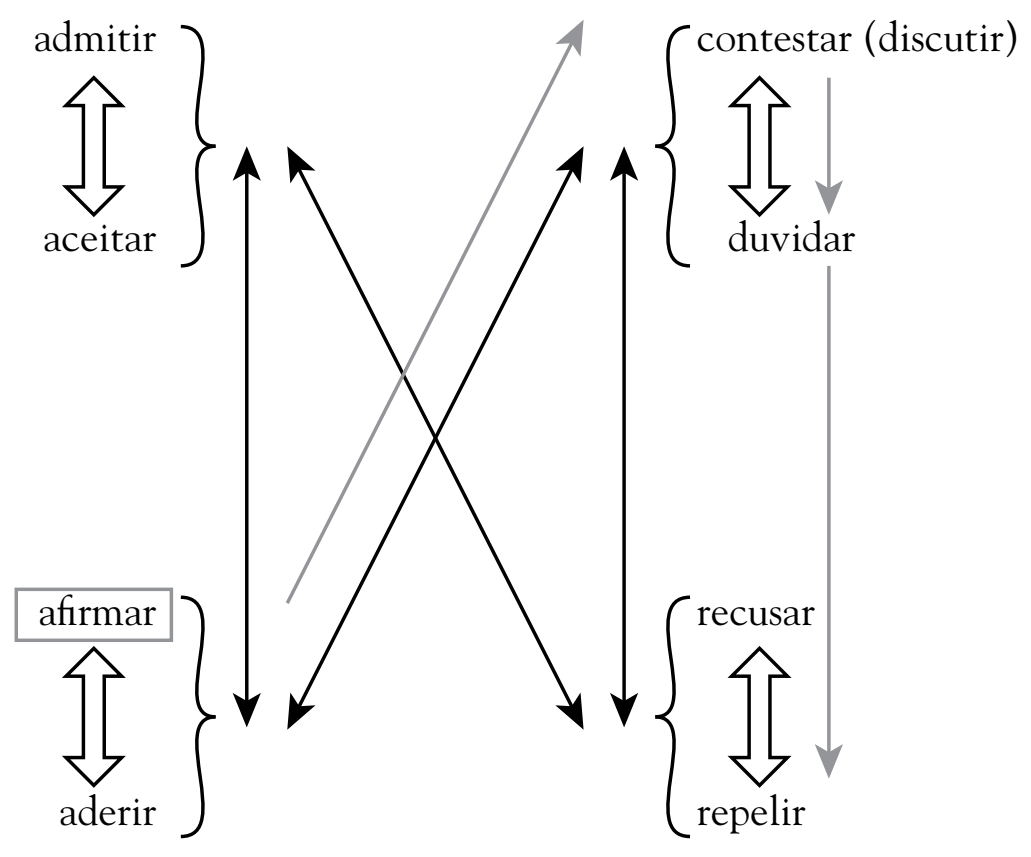

$\longleftrightarrow$ transformações sobre o quadrado epistêmico, comuns aos dois sistemas, visto que cada modificação em um pressupõe uma modificação virtual no outro; estes são os percursos regressivos (negação) e progressivos (afirmação).

$\Longrightarrow$ transformações entre os dois sistemas, por virtualização do precedente e atualização do precedido; estes são os percursos transgressivos.

(Fontanille, 1982, p. 28)

O percurso affirmer - contester é regressivo e, da contestação à dúvida, temos o percurso transgressivo. Ao duvidarmos, saímos do sistema do SABER em direção ao sistema do CRER para repelirmos o que sabíamos. A dúvida, assim, deve ser "sempre idolatrada" porque ela nos impede de, em percurso também transgressivo, sairmos do sistema do SABER e entrarmos no sistema do CRER ao deixarmos de afirmar para passarmos a aderir a algo, criando um dogma. Esquematicamente, ela nos impede de realizar o seguinte percurso: 


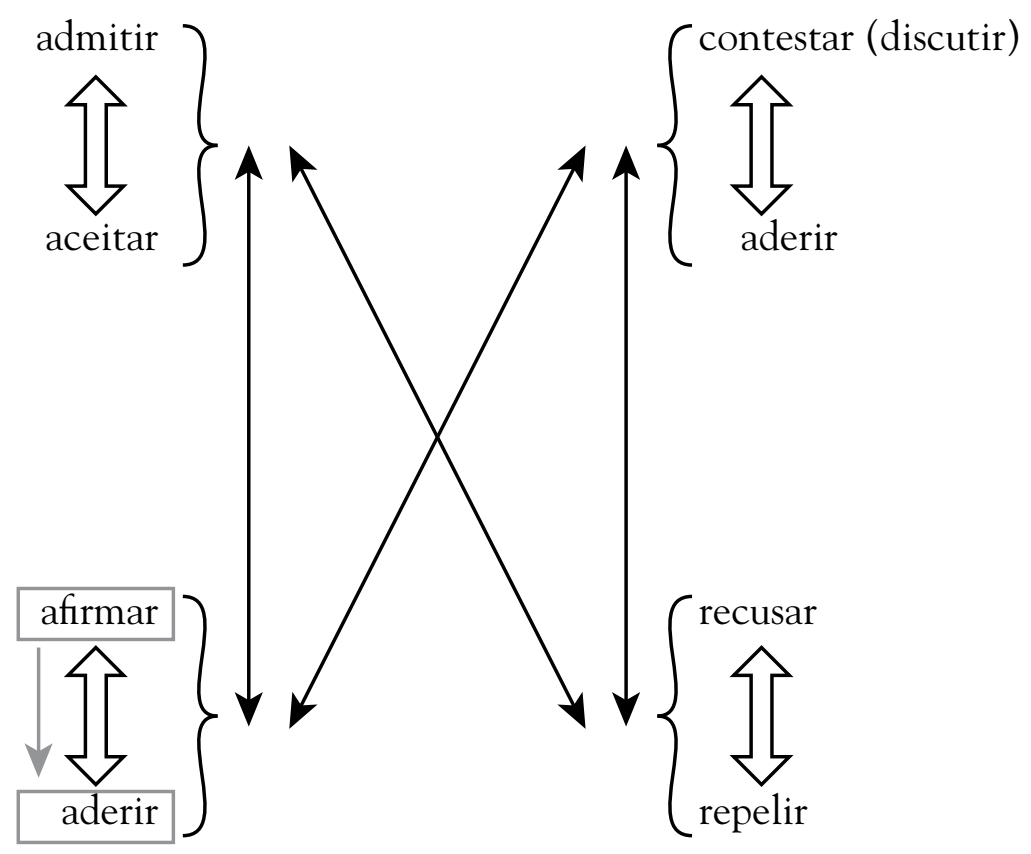

$\longleftrightarrow$ transformações sobre o quadrado epistêmico, comuns aos dois sistemas, visto que cada modificação em um pressupõe uma modificação virtual no outro; estes são os percursos regressivos (negação) e progressivos (afirmação).

$\longrightarrow$ transformações entre os dois sistemas, por virtualização do precedente e atualização do precedido; estes são os percursos transgressivos.

(Fontanille, 1982, p. 28)

Desse modo, ao trilharmos percursos transgressivos em nossas operações de adequação cognitiva, estamos garantindo dinamicidade a uma construção de conhecimento que, somente se for dinâmica, conseguirá fugir ao dogma. 


\subsection{O crer na ciência - A questão da aposta}

A concepção de ciência construída no poema que acabamos de analisar é contrastada à ignorância engendrada via CRER: corresponde a um território cognitivo isento de fé ou de crenças. Apenas no âmbito científico o sujeito poderia de fato alcançar a verdade sobre seus objetos cognitivos, entrando em contato direto com conteúdos da ordem do SABER. Tal noção do SABER deixa transparecer, em certa medida, alinhamento com aquela apontada por Fontanille (1987, p. 9) como própria da semiologia dos anos 1960 que, com base nas teorias da informação e da comunicação, limitava a questão do SABER à transmissão de um conteúdo entre um destinador e um destinatário.

O que teríamos no domínio da ciência, segundo o poema, seria a circulação de um "saber compartilhado, posto em comum" (Fontanille, 1987, p. 9) predominantemente por meio de um fazer-SABER, cuja existência semiótica já foi problematizada no capítulo 2. Fontanille, em Le savoir partagé (1987), também chama a atenção para a inconsistência da noção da linguagem como transmissora de informações, apontando que "ela o faz, certamente, mas manipulandoas, deturpando-as, explorando-as com fins estratégicos cuja transmissão de informação propriamente dita é apenas um caso particular, quando não é um pretexto" (Fontanille, 1987, p.9-10). É a partir dessa observação que o semioticista opõe ao saber "posto em comum" ao saber "dividido, quebrado", que exigiria, portanto, para sua compreensão e para a descrição de seu funcionamento, a abordagem das operações fundamentais da discursivização própria do que ele apresenta como uma "epistemologia semiótica", ou "epistemologia interna", que pode ser definida concisamente como "o estudo da economia do saber nos discursos" (Fontanille, 1987, p. 11).

O que procuramos destacar aqui é o fato de que a ciência, enquanto prática e ética discursiva, também alcança efeitos de verdade através de procedimentos linguísticos, ou seja, cerca-se de modo incontornável de estratégias de manipulação e de veridicção que almejam ao parecer-verdadeiro. Porém, a carga de CRER que perpassa a prática científica, de acordo com o ponto de vista de estudos semióticos mais atuais, parece não se limitar àquela que vem a reboque da enunciação ou da instauração da comunicação, para a qual o CRER configura o "prelúdio" elementar segundo Greimas (1983, p. 123). 
Ao se propor compreender a diferença entre o CRER e o SABER e, consequentemente, entre crenças e verdades, que circulariam cada qual de forma supostamente exclusiva (como vimos no poema analisado no tópico anterior) em seu respectivo universo de racionalidade, Fontanille (2007, p. 227) apresentanos a já mencionada relação triangular relativa ao CRER, em que a instância do discurso toma posição entre dois objetos cognitivos, e a relação estrita entre os objetos cognitivos própria do SABER. Porém, sobre a exatidão desse modelo, o próprio autor ressalta que: "A distinção entre esses dois valores é, por vezes, frágil, pois, no processo permanente da formação dos saberes e de sua conexão, é bem difícil provar que a instância de discurso nunca toma posição" (Fontanille, 2007, p. 227). Afirmação que, por conseguinte, vem a explicitar a problemática noção de ausência de crenças no âmbito da ciência.

Em Le sasoir partagé, Fontanille (1987, p. 57) introduz o conceito de "teoria de suplência" ao analisar brevemente as operações cognitivas e juízos epistêmicos do protagonista e narrador em primeira pessoa do conto Le Horla (1887), de Guy de Maupassant. Esse personagem passa a sentir à sua volta, de modo crescente, a presença de um ser invisível e estranho, a quem decide chamar de "o Horla”. Segue-se, então, uma série de provas que assumem a forma de uma demonstração quase experimental da existência objetiva desse ser: o protagonista constata que alguém bebe seu leite e sua água durante a noite, flagra um botão de rosa curvando-se pela haste como se alguém invisível a forçasse, surpreende-se por sua imagem não se refletir mais no espelho e acaba por concluir que o Horla definitivamente existe por ler em um jornal vindo do Brasil que em São Paulo a população vinha sendo atacada durante o sono por vampiros invisíveis que bebiam água e leite.

Em sua busca pela verdade, o narrador de Le Horla acumula, assim, referências que se tornam para ele indiscutíveis e decisivas sobre a existência do ser invisível. Se esse sujeito, porém, chega à certeza, como afirma em: "Tenho certeza agora, como tenho certeza da sucessão dos dias e das noites, que há junto de mim um ser invisível" (Maupassant, 2003, p. 178), Fontanille aponta que é por meio do que denominará, então, como uma "teoria de suplência". Ela é exemplificada através do seguinte excerto do conto de Maupassant: 
Desde que o homem começou a pensar, desde que ele conseguiu dizer e escrever seus pensamentos, sente-se tocado por um mistério impenetrável a seus sentidos grosseiros e imperfeitos, e procura suprir, pelo esforço da sua inteligência, a incapacidade de seus órgãos. (Maupassant, 2003, p. 175)

A partir deste trecho, Fontanille afirma que "a teoria da suplência funda crenças sobre a insuficiência do saber" e aponta que "Maupassant enumera aquilo que ele entende como crenças de suplência: sobrenatural, lendas, religiões e até mesmo magnetismo e descobertas científicas recentes" (1987, p. 57). Para o semioticista, temos aí formulado o paradoxo: o de que "a ciência nada mais faz do que descobrir aquilo que os homens visam por meio de suas crenças há séculos" (Fontanille, 1987, p. 57).

A concepção de que a ciência não descobre coisas, mas antes as reconhece por meio de uma ação que é preponderantemente regulatória sobre práticas e discursos humanos, ao mesmo tempo em que trabalha não sobre a "realidade" do mundo que se lhe apresenta empiricamente, mas essencialmente sobre construções discursivas dotadas de sentido - e por meio de procedimentos inescapavelmente linguísticos -, é encontrada também em Lopes e Beividas (2007), como podemos observar no seguinte trecho, inserido na altura do texto em que se discute o controle de adequação como uma das funções do ato epistêmico:

Talvez a própria ciência não possa assegurar outro procedimento senão o desse ajuste de adequação entre os discursos científicos já enunciados e as novas proposições; nesse sentido, seria a ciência, mais que uma eventual "descoberta" da realidade mesma, um ajuste e adequação de discursos que permitem a comunicação e a comparabilidade desses próprios discursos no seio da comunidade de cientistas. Ou ainda: a ciência não como captação do real, mas como a construção de uma linguagem, a sua linguagem; enfim, o mundo também dos cientistas como uma "macrossemiótica" a ser disputada pelos vários "pontos de vista" e não como um discurso que vocifere sobre a "realidade última” das coisas. (2007, p. 36) 
Ainda sobre as condições de "verdade" da ciência, Coquet, em seu artigo "Le discours de la véridiction" (1983), ao apontar que no discurso encontramos a relação de equivalência "verdade (veridicção) $\approx$ realidade", que tem caráter aproximativo e, mais exatamente, "dá vantagem ao dizer-verdadeiro, como se o actante sujeito estivesse menos certo de poder ter o discurso da realidade do que o da verdade" (Coquet, 1983, p. 58), afirma também o seguinte:

Mesmo no domínio das ciências, o conceito de realidade varia de acordo com o modelo de referência. Não podemos negar, por exemplo, que o peso é um fato real, mas se nos colocarmos no interior da teoria geral da relatividade, <a força newtoniana de gravitação (...) nada mais é que uma aparência que reflete, para nossos olhos, essa realidade que é a curvatura do Universo $>{ }^{30}$. Assim, os domínios do ser e do parecer não têm fronteiras fixas. (1983, p. 58)

Nesse sentido, Coquet menciona a existência de uma "realidade próxima", que corresponde à nossa experiência cotidiana, e uma "realidade distante" (Coquet, 1983, p. 58), que, em seu exemplo extraído do campo da física, corresponde à experiência do especialista em mecânica quântica. $\mathrm{O}$ autor defende que "quando evocamos a realidade, somos confrontados por um tipo de discurso veridictório e pelo campo que ele pretende cobrir" e, portanto, é preciso observar previamente "que o ato de enunciação (...) implica que um ‘campo posicional do sujeito' seja delimitado" (Coquet, 1983, p. 58).

A partir da noção de que é necessário especificar o "valor da verdade" (Coquet, 1983, p. 58), que pode ser tanto universal quanto local, o semioticista retoma em seu artigo três fórmulas discursivas concebidas por Alain Berrendonner em Éléments de pragmatique linguistique (1981). Tais fórmulas, uma vez escalonadas, representam três valores de verdade, do mais universal ao mais local: "p est IL vrai", "p est ON vrai" e "p est JE vrai". À primeira vista, sua estrutura remete-nos às construções proposicionais como "Je crois que p" ou "Je sais que p", que seguem a expressão $\mathrm{C}_{\mathrm{S}}(\mathrm{p}) \equiv$, em que o sujeito $\mathrm{S}$ acredita que p, e onde p é um enunciado indeterminado, próprias da abordagem encontrada em disciplinas como a Semântica e a Pragmática acerca do SABER e do CRER. Esta é uma das duas maneiras de abordar a problemática do CRER segundo Petitot (1983, p. 237). A outra é a perspectiva que pode ser adequadamente acionada a partir da concepção greimasiana das estruturas semio-narrativas e, de acordo com o semioticista, "consiste em tratar a crença não como uma opinião, mas 30 B. d'Espagnat, A la recherche du réel. Gauthier-Villars, 1980, p. 79 - 80. 
como uma adesão vital aos ideais que determinam o sentido do ser do sujeito, como a mola de uma vontade prática necessária à regulação e à finalização da ação" (Petitot, 1983, p. 237).

Porém, apesar de remeterem estruturalmente às expressões semânticas que tratam o CRER em sua relação com o SABER como uma atitude proposicional, as fórmulas discursivas elaboradas por Berrendonner e retomadas por Coquet pouco têm em comum com abordagens dessa natureza, que se ocupam, como destaca Petitot (1983, p. 237), da análise "de lógicas intensionais epistêmicas (...) ou ao estudo de estratégias comunicacionais subjacentes aos diversos empregos contextuais de $\mathrm{C}_{\mathrm{S}}(\mathrm{p})$ ". O que temos em Berrendonner são fórmulas que procuram dar a noção da extensão de uma "verdade" em estreita relação com a tomada de posição (no mundo) do sujeito que a enuncia. Não à toa, seu sistema faz uso de três pronomes, IL, ON, JE, que nos remete às operações de debreagem (no "IL" da fórmula mais universal) e embreagem (no "JE" contido na formulação mais local) discursivas.

Procuraremos nos ater às duas primeiras, "p est IL vrai" e "p est ON vrai", que contemplam, enquanto formulações teóricas, nossa discussão acerca das condições de verdade na ciência. Para introduzir a primeira e mais geral das fórmulas, Coquet aponta que "a própria língua sabe distinguir, de fato, e articular uma com a outra 'pessoa humana' e "pessoa do universo" (Coquet, 1983, p. 62). Para o autor, essas duas "pessoas" têm um estatuto desigual e aquela "do universo" é transcrita pelo "il" de verbos impessoais e remete a uma instância superior, em que se refuta a análise dos fenômenos (Coquet, 1983, p. 62). Transpondo seu exame para o plano espacial, Coquet destaca que G. Moignet ${ }^{31}$ afirma que o "il", de "il pleut" e "il faut", por exemplo, "'cobrem toda a extensão do universo" enquanto a pessoa humana "por ser uma projeção do $e u$, caracteriza-se pela estreiteza" (Coquet, 1983, p. 62). De sua parte, então, Coquet acrescenta que "dizemos, no mesmo espírito, que um enunciado veridictório tem sua extensão máxima quando ele veicula uma verdade apresentada como universal" (1983, p. 62), e esse tipo de enunciado é simbolizado pela fórmula discursiva: "p est IL vrai".

No patamar de uma verdade menos universal e mais local, mais ainda não correspondente àquela de um actante individual, identificado por Coquet como o sujeito poético que é, em última instância, o mestre da sua verdade (Coquet,

31 G. Moignet. "Personne humaine et personne d'univers...".In: Travaux de linguistique et littérature, Strasbourg, 1970, I, p. 193, 196 e 198. 
1983, p. 70) e representado pela fórmula "p est JE vrai", temos o arranjo "p est ON vrai". Coquet comenta que a escolha do pronome "ON" para representar esse segundo tipo de discurso veridictório se dá pelo fato de esta partícula ter o poder de exprimir, em francês, devido à sua grande plasticidade semântica, aquilo de que o "IL", pessoa do universo, não dispõe: a "generalidade indecisa" segundo proposição de Benveniste em Problèmes de linguistique générale I (1966, p. 235).

Coquet, então, aponta que os discursos organizados pela fórmula "p est ON vrai" repousam sobre uma verdade comum, mas não universal, e chama a atenção para um aspecto caro à reflexão por nós proposta:

Para que um saber tenha garantias suficientes de verdade, basta, em resumo, que uma comunidade o adote. Assim, com "p est ON vrai”, nós deixamos o reino da certeza admitida por todos, para entrar naquele de uma certeza admitida por alguns. Se nos voltarmos ao campo da investigação científica, problemas análogos se colocam. O crédito dado a um saber é função do grupo que o considera justamente como estabelecido. (Coquet, 1983, p. 67)

Uma relação que se dá, então, no âmbito da produção científica é a de que "o pesquisador almeja que seu discurso passe do 'p est $\mathrm{ON}$ vrai' ao decisivo "p est IL vrai', mas a operação de transferência (...) nem sempre pode ser praticada." (Coquet, 1983, p. 68). Desse modo, pelo que nos apresenta Coquet em seu artigo, podemos assumir que alguns enunciados veridictórios próprios do discurso científico de fato se alçam à posição de "verdades universais" e gozam de ampla, senão máxima, extensão - este seria talvez o caso, em exemplo proposto por nós, de “a Terra é redonda”. Não obstante, Coquet exemplifica a fórmula discursiva "p est IL vrai" em seu artigo com o seguinte enunciado: "Deus é infinito; todo corpo é divisível; o todo é maior que a parte" ${ }^{2}$ (Coquet, 1983, p. 63).

A partirdajustaposição de proposições desse modo apresentada,poderíamos à primeira vista pensar que as "verdades universais", de acordo com o que defende Coquet, seriam encontradas tanto no domínio das práticas discursivas religiosas ligadas ao CRER, com as quais identificamos produções discursivas do tipo "Deus é infinito", quanto junto às práticas discursivas científicas associadas

32Exemplo extraído por Coquet de Arnaud et Lancelot, Grammaire générale et raisonnée,

Republications Paulet, 1969, p. 71 
ao SABER, às quais se alinham enunciados como "o todo é maior que a parte", dado alegadamente extraído do "real" por meio da observação empírica. Porém, algumas páginas adiante, Coquet relacionará o "p est IL vrai” diretamente ao SABER, onde encontramos uma "objetividade forte" que não se furta de dizer a verdade pois é o "fiel reflexo da realidade" (Coquet, 1983, p. 68) e proporciona certezas ao sujeito, e "p est ON vrai" ao CRER, domínio da "objetividade fraca" e da quase-certeza.

Uma importante distinção atrelada a esse aspecto é a diferenciação feita por Coquet entre "verdade" e "realidade". Enquanto a "verdade", mais ou menos universal ou local, relaciona-se em seu modelo descritivo com as fórmulas discursivas "p est IL vrai", "p est ON vrai" e "p est JE vrai", suas considerações acerca do "real" são de outra ordem, apesar de se encontrarem associadas às fórmulas sugeridas. O autor considera que, por exemplo, em "p est IL vrai" o "real" 33 se encontra disjunto do "não-real" ( $\hat{\mathrm{e}} \vee \hat{\mathrm{p}})$, sendo esse um arranjo de exceção de que gozam apenas as verdades universais, que proporcionam ao sujeito uma certeza:

\begin{tabular}{l|l} 
verdade & p est IL vrai \\
\hline realidade & $\hat{\mathrm{e}} \vee \hat{\mathrm{p}}$
\end{tabular}

(Coquet, 1983, p. 69)

As fronteiras entre o "real" e o "não real", porém, não são fixas e eles podem se aproximar $(\hat{\mathrm{e}})(\hat{\mathrm{p}})$, se intercruzar $(\hat{\mathrm{e}} \chi \hat{\mathrm{p}})$, e se juntar $\hat{\mathrm{e}} \wedge \hat{\mathrm{p}}$, configurando o que Coquet denomina como uma "realidade indecisa" em que "a competência cognitiva do actante sujeito é 'fraca', pois ele se apoia apenas em uma quasecerteza":

33 A concepção de "real" empregada por Coquet para fomentar sua argumentação é aquela concebida e "dita pelo físico como material e independente das nossas percepções sensoriais ou de nossos meios de investigação" (Coquet, 1983, p. 68). 


\begin{tabular}{l|c} 
verdade & p est $\mathrm{ON}$ vrai \\
\hline realidade & $(\hat{\mathrm{e}})(\hat{\mathrm{p}}), \hat{\mathrm{e}} \gamma \hat{\mathrm{p}}, \hat{\mathrm{e}} \wedge \hat{\mathrm{p}}$
\end{tabular}

(Coquet, 1983, p. 69)

É ao final da apresentação de tais quadros que Coquet associa "p est IL vrai" à objetividade forte e ao SABER, e "p est ON vrai” à objetividade fraca e ao CRER. A partir desse gesto metodológico, questionamos: a ciência não opera também, ao menos nos momentos iniciais de uma teoria, no domínio do "p est ON vrai", associado ao CRER, como observamos no trecho do próprio Coquet (1983, p. 68): "O pesquisador almeja que seu discurso passe do 'p est ON vrai' ao decisivo "p est IL vrai'"?

A existência de uma crença inicial ou de um ato de fé que sustenta o momento de nascimento de uma teoria ou hipótese científica parece-nos pertinente e está atrelada ao que defendemos, ao final do item 3.2 "CRER-SABER, SABER mal e SABER pouco: análise de três operações cognitivas em um poema”, como uma dinamicidade necessária à produção de conhecimento. $\mathrm{O}$ caráter dinâmico, como vimos, estaria garantido ao sujeito pela possibilidade de trilhar percursos transgressivos (Fontanille, 1982, p. 25), que consistem em sua passagem do sistema de adequação cognitiva do CRER para o sistema do SABER, e viceversa. Dito de outra forma, defendemos que, para que o sujeito conheça algo de seu mundo ou produza qualquer tipo de conhecimento, é preciso que ele se modalize de acordo com um CRER, depois com um SABER, depois com um CRER, e assim por diante, em uma estrutura dinâmica e contínua de operações cognitivas.

$\mathrm{O}$ ato de fé aderido ao gesto inaugural de uma teoria ou hipótese aparece semiotizado na seguinte formulação de Fontanille, que o identifica com a figura da "aposta" e, para explicar seu plano de fundo modal, justapõe os universos de racionalidade do CRER e do SABER, em uma espécie de contínuo atravessado pelo sujeito: 
A aposta é sem dúvida a mais bela figura simbólica de um percurso transgressivo: o universo do saber queima seus últimos cartuchos e prepara o terreno para o universo do crer (...). A noção de aposta, ela mesma, é ambivalente: um cálculo sistemático de chances e portanto de probabilidades de um lado e um gesto de adesão e fé do outro. (Fontanille, 1982, p. 29)

A trajetória cognitiva dinâmica, na qual o sujeito não pode prescindir nem do CRER e nem do SABER para construir e conhecer seu objeto cognitivo, parece-nos bem representada em Pottier (1983, p. 273). Este semioticista, que procura orientar muitas de suas análises numa direção guillaumiana, ou seja, "onde o tempo e o contínuo ocupam posição privilegiada" (Lopes, 2004, p. 51), apresenta-nos uma solução gráfica para a alternância cíclica entre CRER e SABER que defendemos como motor modal da produção de conhecimento.

Em seu artigo "Le croire dans une perspective sémio-linguistique dynamique", Pottier introduz o ciclo do conhecimento/memória e o ciclo da fé, vistos no capítulo 2 desta dissertação, ambos arranjos alicerçados sobre uma onda sinusoidal, que expressa a alternância ordenada, ao longo do tempo, do eixo conceitual $(-1 / 0 /+1)$ quando posto em "cronoexperiência pragmática" (Pottier, 1983, p. 272). Essencialmente, esse eixo é recoberto semanticamente pelos termos do quadrado epistêmico como propostos por Pottier mais o termo "excluído", que ocupa a posição -1. Especificamente para compor os ciclos do conhecimento (ligado ao SABER) e da fé (associado ao CRER), Pottier emprega, respectivamente, /ignorar/, /aprender/, /saber/, /esquecer/, /ter esquecido/, /se lembrar/, /saber de novo/; e /ser descrente/,/se converter/,/ter fé/,/perder a fé/, /ter perdido a fé/, /reencontrar a fé/, /crer de novo/.

Os termos assim distribuídos em dois ciclos de base epistêmica remetenos aos dois quadrados que comportam as operações cognitivas próprias ao sistema do SABER (admitir, contestar, afirmar e recusar) e do CRER (aceitar, duvidar, aderir e refutar) como concebidos por Fontanille (1982). Em ambos os arranjos, a dinamicidade do sujeito em relação a suas operações cognitivas no interior de cada ciclo ou sistema é garantida: pela alternância cíclica ao longo do tempo de Pottier e pelos percursos progressivos e regressivos de Fontanille. A noção de percurso transgressivo, então, é a formulação teórica de Fontanille que coloca esses dois sistemas em relação, tornando-os intercambiáveis por um mesmo sujeito cognitivo pressuposto. Uma evidência de que a dinamicidade é elemento pertinente desse modelo teórico pode ser observada na denominação final de 
Fontanille para a estrutura que põe os sistemas de adequação do CRER e do SABER em relação: "forma global de interpretação dinâmica das operações cognitivas" (1982, p. 28), estrutura que já foi vista em vários pontos desta dissertação:

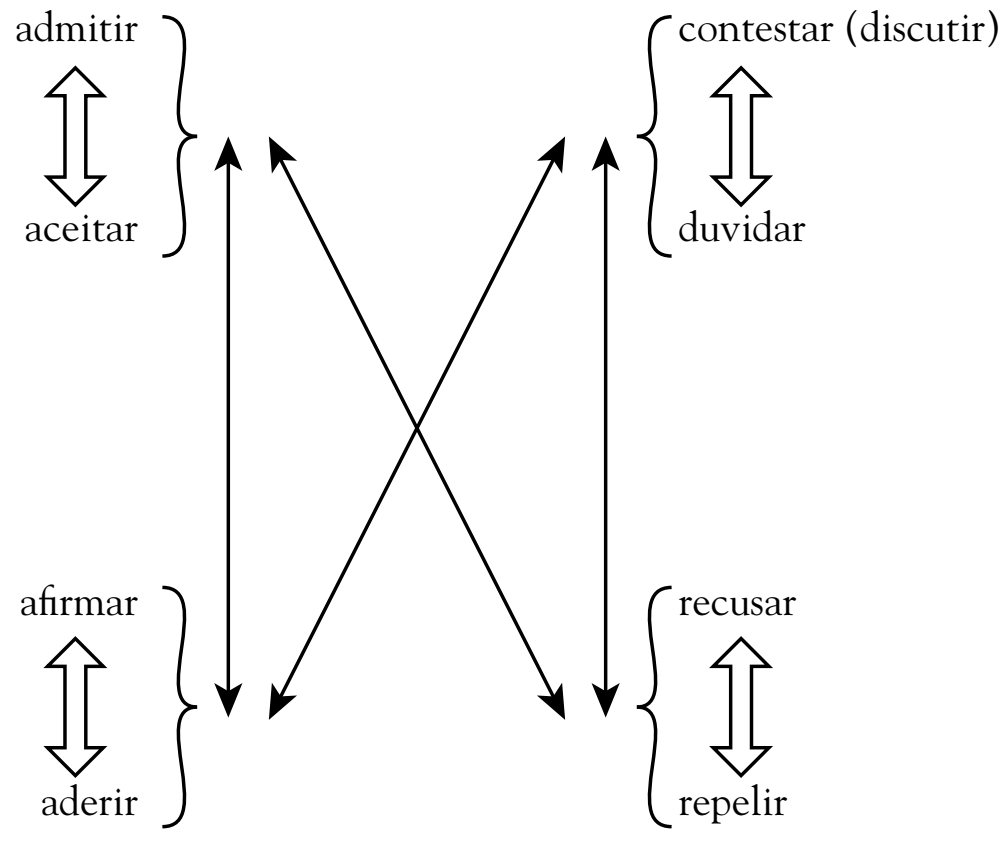

\footnotetext{
$\longleftrightarrow$ transformações sobre o quadrado epistêmico, comuns aos dois sistemas, visto que cada modificação em um pressupõe uma modificação virtual no outro; estes são os percursos regressivos (negação) e progressivos (afirmação).

$\longrightarrow$ transformações entre os dois sistemas, por virtualização do precedente e atualização do precedido; estes são os percursos transgressivos.
}

(Fontanille, 1982, p. 28)

Do mesmo modo, Pottier também põe SABER e CRER em relação ao apontar que, apesar de os ciclos do conhecimento/memória e da fé serem ordenados pelo eixo que vai do 0 ao +1 , o movimento que percorre e oscila por esses limites pode se exceder e ultrapassar os limiares estabelecidos. Como já vimos no capítulo precedente, de modo sucinto, o autor afirma que, quando isso acontece, “alcançamos o 'conhecimento absoluto', aquele da fé” (Pottier, 1983, p. 273), e apresenta a seguinte representação gráfica dessa travessia: 


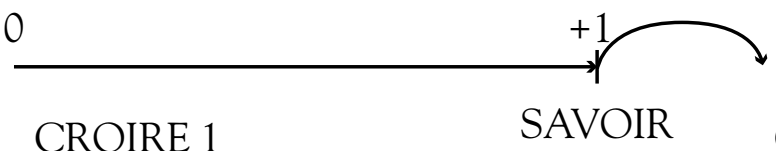

CROIRE 1

SAVOIR

CROIRE 2

(Pottier, 1983, p. 273)

O comentário de Pottier sobre o gráfico acima, então, resume-se a dois breves parágrafos, que dizem:

O sábio, homem do saber, tenta se aproximar constantemente da certeza, mas os progressos da ciência apenas repelem eternamente o conhecimento.

Por outro lado, o crente, homem de fé, possui a convicção do saber absoluto. (Pottier, 1983, p. 273)

O que temos aqui é uma formulação ousada que aponta SABER e conhecimento na crença. A adjetivação por nós empregada em relação à afirmação de Pottier se justifica se tomarmos como comparativo um posicionamento mais geral, tido como não-ousado, que muitos semioticistas assumem ao caracterizar, talvez em busca de contraste descritivo, o CRER como promotor de um tipo de compreensão mais precária e obscurecida do mundo, ao passo que por meio do SABER alcançaríamos um efeito objetivante forte, um parecer-verdadeiro mais eficaz e capaz de nos aproximar ao máximo, na medida do possível em um mundo apreendido por meio da semiose, da real "verdade" das coisas.

Um exemplo dessa tendência pode ser observado em Coquet (1983, p. 63 - 69), que inicialmente sinaliza para a possibilidade de "verdade universal" na crença ao exemplificar a fórmula "p est IL vrai” com o enunciado veridictório "Deus é infinito", mas depois recua e aloca, de maneira bastante convencional, o CRER ao lado da "objetividade fraca" e da "quase-certeza", contrastado ao SABER da "objetividade forte", da "certeza" e produtor de verdades de ampla extensão do tipo "p est IL vrai".

É importante destacar, porém, que não defendemos que seja por meio somente do CRER que o sujeito logre compreender melhor seus objetos, mas tampouco endossamos a noção de que por meio exclusivo do SABER se conheçam 
"verdades" de modo mais eficaz. De acordo com a visada semiótica do mundo, que o aponta como categorizado e, em última instância, construído pela linguagem, tudo de que o sujeito dispõe são discursos mais ou menos verossímeis e, para que ele complete seu fazer-interpretativo sobre estes, parece-nos inescapável que acione alternadamente seus dois sistemas de adequação cognitiva, modalizandose de forma dinâmica ora de acordo com um SABER, ora de acordo com um CRER, em um arranjo contínuo e cíclico à la Pottier; por vezes extenuando e anulando seus objetos de acordo com um SABER, e por outras conservando-os por meio do CRER, como postula Zilberberg (2006, p. $142-143)$.

Desse modo, consideramos improvável encontrar no âmbito da ciência o exercício de um SABER puro. Primeiramente porque, de acordo com o que defende Zilberberg (2006, p. 142 - 143), no quadro modal de um SABER contínuo, os valores remissivos seriam privilegiados e o que teríamos seria apenas a destruição e a anulação dos objetos. Ora, em ciência deparamos-nos com diversos processos de conservação, cognitivos e também pragmáticos, como é o caso do confinamento de objetos do SABEr em museus. Para Zilberberg (2006, p. 144), o museu é um espaço que serve de exemplo como reduto espacial tipicamente criado via CRER para preservar seus objetos, em uma atividade estetizante, que é "conservadora como um culto, uma devoção". De fato, os museus constituem-se como espaços de concentração, e em certa medida reverência, ao conhecimento adquirido e acumulado pela humanidade.

Não concebemos, ainda nesse sentido, a incidência do CRER sobre a prática científica como restrita aos discursos de divulgação da ciência, em que se acionariam preponderantemente estratégias discursivas como a persuasão, na instância na enunciação, com vistas ao fazer-CRER. Consideramos também que a presença do CRER vai ainda além do episódico momento de aposta inicial em uma disciplina, hipótese ou teoria científica que se fundam.

Defender a fé ou a presença da crença somente no gesto inaugural de uma teoria científica seria como defender o CRER, no âmbito do esquema narrativo canônico, como restrito, por exemplo, aos momentos da manipulação fiduciária e do encerramento narrativo, quando se dá o juízo epistêmico do sujeito durante a etapa da sanção.

Preterimos tal noção compartimentada do CRER, que teria contribuições apenas pontualmente pertinentes na instância da enunciação e em determinadas etapas do esquema narrativo, em benefício de uma abordagem que busca 
compreender, descrever, explicar e até mesmo representar graficamente a dimensão cognitiva como uma estrutura dinâmica onde se dá um jogo elástico, e cíclico, entre o CRER e o SABER, caracterizador de nossa "situação geral de homens sem garantia de verdade”, (Lopes e Beividas, 2009, p. 447). Assim, fazemos a defesa de que a semiótica da ordem do contínuo é aquela capaz de abordar a ação intermitente, sobre os movimentos cognitivos do sujeito, do CRER, modalidade que inegavelmente tem a sua contribuição para a construção do conhecimento humano, como nos aponta, finalmente, Geninasca no artigo "Composantes thymiques et prédicatives du croire" (1983, p. 111): "O crer, ao qual se limita aqui a minha reflexão, é indissociável da existência de um universo valorizado, ou seja, dotado de sentido para o homem".

\subsection{Enunciação e universo cognitivo: relações de precedência e hierarquização}

Um dos principais parâmetros para o estabelecimento de uma relação de precedência entre os termos CRER e SABER encontra-se compreendido na instância da enunciação. A antecedência sintática do CRER em relação ao SABER é apontada por Fontanille (1987, p. 55) como um dos pontos incontornáveis da distinção paradigmática entre CRER e SABER realizada por Greimas em $D u$ Sens II (1983). Ao destacar esse aspecto teórico que organiza a relação entre os termos, Fontanille faz referência direta ao item "2.2 O crer precede o saber" do texto de Greimas (1983, p. 122), já relativizado ao longo do capítulo 1, visto que o mesmo texto do semioticista lituano comporta, em igualdade de direitos e de consequências teóricas, o item "2.1 O saber precede o crer".

Entendemos que tal precedência do CRER encontra-se em estreita relação com a produção de enunciados ao considerarmos, como faz Fontanille (1987, p. 55), "que nenhum saber saberia ser enunciado sem ser previamente modalizado por um julgamento epistêmico (de certeza, de improbabilidade, etc.), o que o transforma, ipso facto, em crer". Desse modo, podemos identificar que a antecedência sintática do CRER encontra pertinência e aplicação quando nos voltamos às condições iniciais da comunicação intersubjetiva, em que estão pressupostos um "eu creio que" e, correlativamente, um "é preciso que você creia que eu creio que". 
$\mathrm{O}$ estabelecimento de uma precedência dessa natureza forçosamente hierarquiza os termos no sentido de que ordena uma sequência para sua ocorrência no eixo cronológico em que o discurso se dá. Entretanto, ambas as modalidades, nessa abordagem, encontram-se no mesmo nível no percurso gerativo de sentido. Uma primeira evidência de que elas podem ocupar níveis distintos nesse percurso está no arranjo modal CRER-SABER, possível apenas graças à capacidade do CRER em reger outro enunciado modal, característica que o distingue das demais modalidades como aponta Zilberberg (2006, p. 160).

Tal propriedade pode ser relacionada à carga semântica suplementar aderida ao CRER, que Fontanille aponta já no início de Le savoir partagé (1987) como consequência da presença do traço/tímico/neste termo, e posteriormente retoma, em um segundo momento, relacionando-a ao "sistema da marca” (1987, p. 55). De acordo com esse sistema, como já comentamos brevemente no capítulo 1, a distinção entre CRER e SABER não se manifestaria sob a forma de dois traços distintivos em relação à parte inteira, mas pela oposição presença/ausência de um traço de expressão. Desse modo, temos que: "O que caracteriza no plano semântico o sistema da marca é que os dois constituintes da categoria não têm o mesmo estatuto nem a mesma distribuição: um dos dois, o termo não marcado, serve de termo genérico, termo neutro, etc.” (Fontanille, 1987, p. 55).

Tal lógica de presença/ausência de traço de expressão tem como principal consequência teórica, ainda para Fontanille (1987), o fato de que o CRER se torna o termo marcado, e o SABER, o não-marcado - e, devido à carga semântica adicional aderida ao CRER, "eles (os termos) não fazem parte do mesmo nível do percurso gerativo" (Fontanille, 1987, p. 55). A relação entre a diferença de generalidade entre CRER e SABER e a precedência sintática do CRER ao longo das etapas do percurso gerativo de sentido é comentada da seguinte forma por Fontanille:

Assim, no "crescimento" desse percurso, os saberes encontram inevitavelmente os julgamentos epistêmicos, que os convertem em crenças. Do mesmo modo, toda troca de saber, situada em um nível narrativo " $n$ " é sobredeterminada, em um nível " $n+1$ " por uma relação fiduciária. (1987, p. 55)

Nesse trecho, ele traça um paralelo entre o saber de nível "n" ou "semiótico", que "permite uma apreensão de conteúdo de sentido" (Fontanille, 1987, p. 33) 
com o SABER termo não-marcado, e do saber de nível "n+1" ou "meta-semiótico", que "permite uma otimização do (saber como) fazer", com o CRER termo marcado. As noções de termo não-marcado e marcado remete-nos, respectivamente, ao que Hjelmslev define como termos extensivo e intensivo.

A oposição entre os termos hjelmslevianos extensivo e intensivo é do tipo participativa. Ou seja, a mesma observada na categoria semântica e morfológica do gênero gramatical, usada por Fontanille (1987, p. 55) para exemplificar o sistema da marca: enquanto "eles" assume o posto de termo extensivo (nãomarcado), "elas" corresponde ao intensivo (ou marcado). O aspecto "participativo" que denomina e caracteriza a relação advém do fato de que se em "elas" temos forçosamente e exclusivamente representantes do gênero feminino, em "eles", seu termo oposto, encontram-se subsumidos tanto homens quanto mulheres.

Como já mencionamos no início do capítulo 1, as oposições participativas regem os termos da segunda geração do quadrado semiótico: complexo, neutro e dêixis. Os demais termos, de primeira geração, têm origem nas oposições fonológicas binárias desenvolvidas por Jakobson e herdadas por Greimas: os termos contrários são organizados pela oposição qualitativa (A vs. B, como em "dia" vs. "noite"), e os contraditórios pela oposição privativa (A vs. Ã, como em "dia" vs. "não-dia").

Zilberberg, no capítulo de Razão e poética do sentido (2006) intitulado "Atualidade de Brøndal", retoma justamente as formulações de Hjelmslev em relação aos termos intensivo e extensivo ressaltando que: "Brøndal compartilha com Hjelmslev a preocupação de liberar o binarismo daquilo que denominaríamos 'antitetismo primário'” (Zilberberg, 2006, p. 72). Na sequência, Zilberberg mostra, utilizando as convenções gráficas propostas por Hjelmslev em La catégorie des cas (1972, p. 112 - 113), como se apresentam, tanto para Brøndal como para Hjelmslev, as "estruturas elementares" da significação. Ater-nos-emos aqui às formulações de Hjelmslev e, mais especificamente, à representação gráfica que a oposição participativa recebe do linguista dinamarquês: 
1. O par $\alpha / \mathrm{A}$ intensivo-extensivo:

$\alpha$

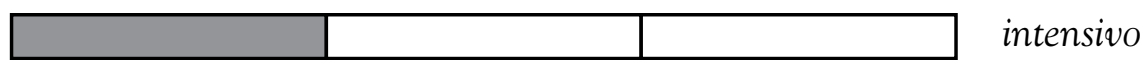

A

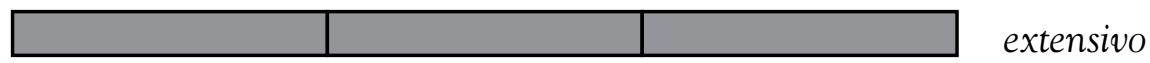

(Zilberberg, 2006, p. 73)

A oposição paradigmática do tipo participativa nos ajuda a abordar e descrever o princípio de organização dos termos CRER e SABER no provérbio citado por Greimas (1983, p. 116) como construção exemplar do funcionamento desses verbos nas línguas naturais, que "se sobrepõem sem se confundir e chegam a de fato se opor":

"Nous savons tous que nous mourrons, mais nous ne le croyons pas"

Todos sabemos que vamos morrer, mas não acreditamos nisso.

Talvez o aspecto que prenda a nossa atenção à primeira vista se deva ao que essa construção proverbial guarda de paradoxal. A noção de paradoxo é empregada por Fontanille (1982, p. 22) para expressar a singularidade da ligação que une o universo de racionalidade do CRER ao universo do SABER. A proposição inicialmente contraproducente, de não acreditar no que se sabe ser verdadeiro, longe de cair no vazio de sentido pelo que contém de ilógico, ganha acentuado efeito verossimilhante pela força e a generalidade da figura que projeta em nível discursivo: a do ser humano que, essencialmente caracterizado por sua condição mortal, se recusa a acreditar que vai morrer. Por meio dela, a construção se alça à posição de "verdade universal", aquela que goza de "extensão máxima" enquanto enunciado veridictório (Coquet, 1983, p. 62), típica das "verdades" veiculadas por meio de construções proverbiais.

A sobreposição dos termos SABER (saber) e CRER (não acreditar) é de fato observada no provérbio. Ela pode ser depreendida a partir da configuração modal do sujeito, que parece acionar operações cognitivas "divergentes" em 
relação a um mesmo objeto. E esse acionamento é simultâneo. Malgrado as modalizações sejam expressas uma após a outra devido a um princípio coercivo de funcionamento da língua, que deve se desenrolar em um eixo de linearidade, a figura só alcança a sua totalidade se as modalizações incidirem ao mesmo tempo sobre o mesmo sujeito: diante de determinado objeto cognitivo, ele sabe $e$ não acredita.

Porém, chamamos atenção para um aspecto sutil concernente à distribuição dos termos: além de simultâneos, um está sobreposto ao outro. A noção de sobreposição remete antes a um posicionamento no espaço do que no tempo, o que oferece à simultaneidade plenas condições de ocorrência. De fato o termo "sobrepor" recebe a seguinte definição dicionarizada:

Sobrepor: v. (sXIII cf. CBN) 1. bit. e pron. Pôr(-se) em cima ou por cima de (alguém ou algo); colocar(-se) sobre <ao novo monarca sobrepôs a real coroa> <uma nuvem escura sobrepunha-se ao pico da montanha> 2. bit. fig. Colocar por cima, para esconder <sobrepôs o riso às lágrimas> 3. bit dobrar por sobre <sobrepôs ao envelope o respectivo fecho> (HOUAISS, 2008, p. 2593, grifos nossos)

Há, assim, hierarquização na simultaneidade de termos sobrepostos, não necessariamente de ordem cronológica, como já vimos, mas no sentido de que um termo se coloca por cima de outro, que já estava lá ocupando sua posição. Propomos uma aproximação deste termo já posicionado com o termo mais geral e não marcado, enquanto o que se coloca por cima do primeiro seria o marcado. Lembrando o que é sugerido por Fontanille (1987, p.55): temos uma diferença de generalidade e de distribuição entre CRER e SABER, o primeiro, o termo marcado e, em formulação hjelmsleviana, intensivo; o segundo, não-marcado e extensivo.

A diferença de generalidade associada ao sistema da marca são princípios que organizam a manifestação da categoria gramatical do gênero, e Fontanille lança mão do exemplo "eles" como termo extensivo que comporta, em sua ocorrência, tanto "eles" como "elas", para em seguida realizar a aproximação por analogia de "eles" (não marcado) com o SABER (não marcado) e de "elas" (marcado) com o CRER "marcado". Sugerimos as seguintes representações gráficas para a distribuição hierarquizada dos termos: 


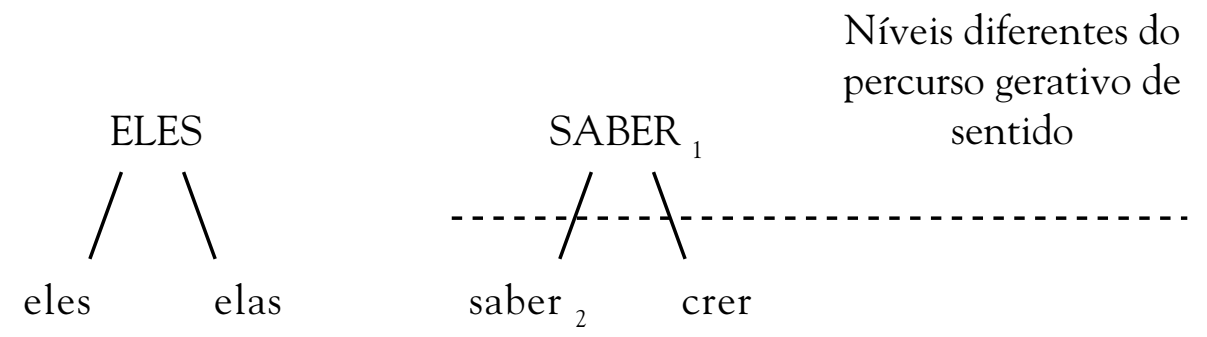

$\mathrm{O}$ que apresentamos aqui são propostas iniciais de abordagem que demandam continuidade de investigação e verificação. A partir desses arranjos, porém, podemos observar uma possibilidade de ordenação da sobreposição dos termos. Assim como ocorre no provérbio, sobre o termo não-marcado e extensivo, deposita-se o termo marcado e intensivo, e não estamos nos referindo à ordem de posposição sintática dos termos no enunciado, como já ressalvamos anteriormente, mas a uma espécie de complexificação ou enriquecimento da configuração modal do sujeito que se dá do nível 1 ao 2 .

Podemos pensar que seja em decorrência desse tipo de sobreposição ordenada que as frases em (a) façam sentido e as de (b) nos pareçam questionáveis:

(a) Ele acredita no que sabe.

Passei a acreditar em tudo o que eu sabia.

Ela tem crença em seus saberes.

(b) *Ele sabe o que acredita.

*Passei a saber tudo o que eu acreditava.

*Ela tem saber em suas crenças.

Nossa proposição pode ser, entretanto, facilmente contestada com o que defende Greimas: a noção de um CRER englobante. "A. J. Greimas sustenta a ideia de que o saber e o crer fazem parte do mesmo universo cognitivo, e até 
mesmo que o crer precede e engloba o saber" (Fontanille, 1987, p. 54) e essa proposição subverteria a ordem de hierarquização por nós proposta para os termos. A sugestão de um "crer englobante" aproxima-o da noção de termo não marcado, mais geral e extensivo.

Porém, e mais uma vez, essa reflexão de Greimas parece se direcionar a um ponto bastante específico do esquema narrativo, o mesmo ao qual relacionamos sua afirmação de que "o crer precede o saber" (1983, p. 122), posteriormente retomada por Fontanille (1987, p. 54) e relativizada por nós, no capítulo 1 desta dissertação, como uma das duas relações de precedência apresentadas como possíveis e relevantes por Greimas em "Le savoir et le croire: um seul univers cognitif" (1983) - a saber: a outra relação estipula que "o saber precede o crer" (1983, p. 117).

Se nos voltarmos, entretanto, ao arranjo CRER-SABER, deparamo-nos com a sugestão de um CRER de ordem mais geral que acomoda um SABER, sobreposto e comandado por ele. Esse arranjo se alinha ao modelo conjecturado por Pottier (1983, p. 268), que aponta o CRER como uma arquimodalidade do tipo epistêmica que engloba, em nível lexical, o saber, e aí teríamos, retomando a estrutura de hierarquização sugerida na página anterior, a relação resolvida por meio de um CRer 1, crer 2 e saber:

$\mathrm{O}<$ movimento de crença> recobre um contínuo conceitual que o locutor é obrigado a tornar descontínuo quando escolhe os signos da língua. Essa liberdade, de fato muito grande, de escolha pode se manifestar no nível lexical (crer, achar, julgar, imaginar, supor, saber...) ou no nível de todos outros arranjos sintáticos fundados sobre o recurso de categorias semântico-gramaticais variadas. (Pottier, 1983, p. 268)

Parece-nos que a concepção de um CRER englobante e sintaticamente precedente na enunciação, como definida em Greimas (1983), encontra amplo consenso dentro da teoria. Um "eu creio que" que pressupõe um "é preciso que você creia que eu creio que" é apontado pacificamente como o arranjo vital ao início de qualquer comunicação. A noção de que uma das modalidades pode assumir um caráter mais extenso e comandar a outra a partir de um nível diferente no percurso gerativo de sentido, como sugere Fontanille (1987), porém, ainda 
merece maior investigação no sentido de definir qual delas está no comando. Desse modo, mantemos os arranjos tanto de um SABER comandando saber $_{2}$ e crer, quanto e de um CRER ${ }_{1}$, organizando crer $_{2}$ e saber, como duas possibilidades de precedência e generalidade que demandam mais estudos.

Finalmente, visto que Fontanille (1987, p. 55) aponta que nenhum SABER poderia ser enunciado sem antes ser modalizado por um julgamento epistêmico e que no desenrolar de um percurso narrativo "os saberes encontram inevitavelmente os julgamentos epistêmicos, que os convertem em crenças", questionamos: qual é o estatuto na teoria semiótica desse SABER que existe antes do CRER, é convertido em CRER por ação de um julgamento epistêmico em um processo desengatilhado pela iminência do ato enunciativo, e que não é considerado precedente?

O SABER como termo não marcado, ou, em formulação hjelmsleviana, extensivo, ao qual sugerimos a representação na forma de um SABER ${ }_{1}$ que comanda um saber 2 e um crer, remete-nos à noção de SABER "contenente de sentido" em nível "n”, como proposto por Fontanille (1987), que se opõe ao SABER “operador modal" (em nível n+1 ou n-1), este já amplamente disseminado, discutido, descrito, empregado e compreendido pela teoria semiótica. A oposição entre o SABER "contenente de sentido" e o SABER "operador modal" é da ordem classêmica e "pode ser interpretada como uma distinção hierárquica" (1987, p. 20 - 21). Enquanto "contenente de sentido" o SABER se caracteriza da seguinte forma:

Como contenente de sentido, o SABER funciona como um vetor no qual um conteúdo é reduzido a uma significação. Transparente ao conteúdo de sentido que veicula, o SABER se diferencia dele unicamente pelo fato de que põe esse conteúdo em relação com o sujeito. (Fontanille, 1987, p. 20)

Se a precedência do CRER na instância da enunciação parece estar bem resolvida e estabelecida na teoria semiótica, se nos afastarmos da relação destinador/destinatário implicada no ato enunciativo, como seria o funcionamento de um SABER precedente? E, antes de tudo, é possível se afastar dessa relação? 
Ainda em Le savoir partagé (1987), Fontanille tende a corroborar essa possibilidade. Ele defende que, "enquanto objeto de valor, o saber propriamente dito é um objeto conquistado ou construído por um sujeito operador autônomo (...) que exclui a intervenção de um destinador exterior para garantir o saber" (1987, p. 56). Uma diferença apontada como actancial, mas também axiológica, entre o CRER e o SABER, para Fontanille, é que este é construído de forma individual, em uma relação imediata entre sujeito e objeto, e aquele é sempre adquirido, em dependência da ligação entre destinador e destinatário. Em texto anterior, de 1982, Fontanille também já havia feito a defesa da dominância da relação $\mathrm{S} 2$ - O (sujeito - objeto) no sintagma intersubjetivo próprio ao universo de adequação cognitiva do SABER, onde a ligação às pessoas é preterida em benefício da ligação às ideias.

Um contraponto, porém, que entendemos que deve ser feito é o seguinte: mesmo nesse tipo de relação não mediada entre sujeito e objeto, em que a figura do destinador se encontra suprimida, não seria necessário o mínimo de crença ou de fé para dotar um objeto de sentido, como ressalta Geninasca (1983, p. 111) ao apontar que o CRER é indissociável de um universo dotado de sentido para o homem?

De qualquer modo, o conceito de SABER de nível "n”, semiótico, "que permite uma apreensão do conteúdo de sentido" (Fontanille, 1987, p. 33) é talvez o que temos de mais próximo de uma noção semiotizada da percepção do fenômeno por parte sujeito. A questão da percepção, em estreita ligação com a significação e a construção de sentido por meio da linguagem, é o tema central da análise apresentada no capítulo seguinte. Parece-nos que, não por acaso, o objeto central dessa análise é um sujeito estritamente do SABER, de um SABER desmedido e exorbitante, Funes, o memorioso, protagonista do conto homônimo de Jorge Luis Borges. 


\section{Capítulo 4}

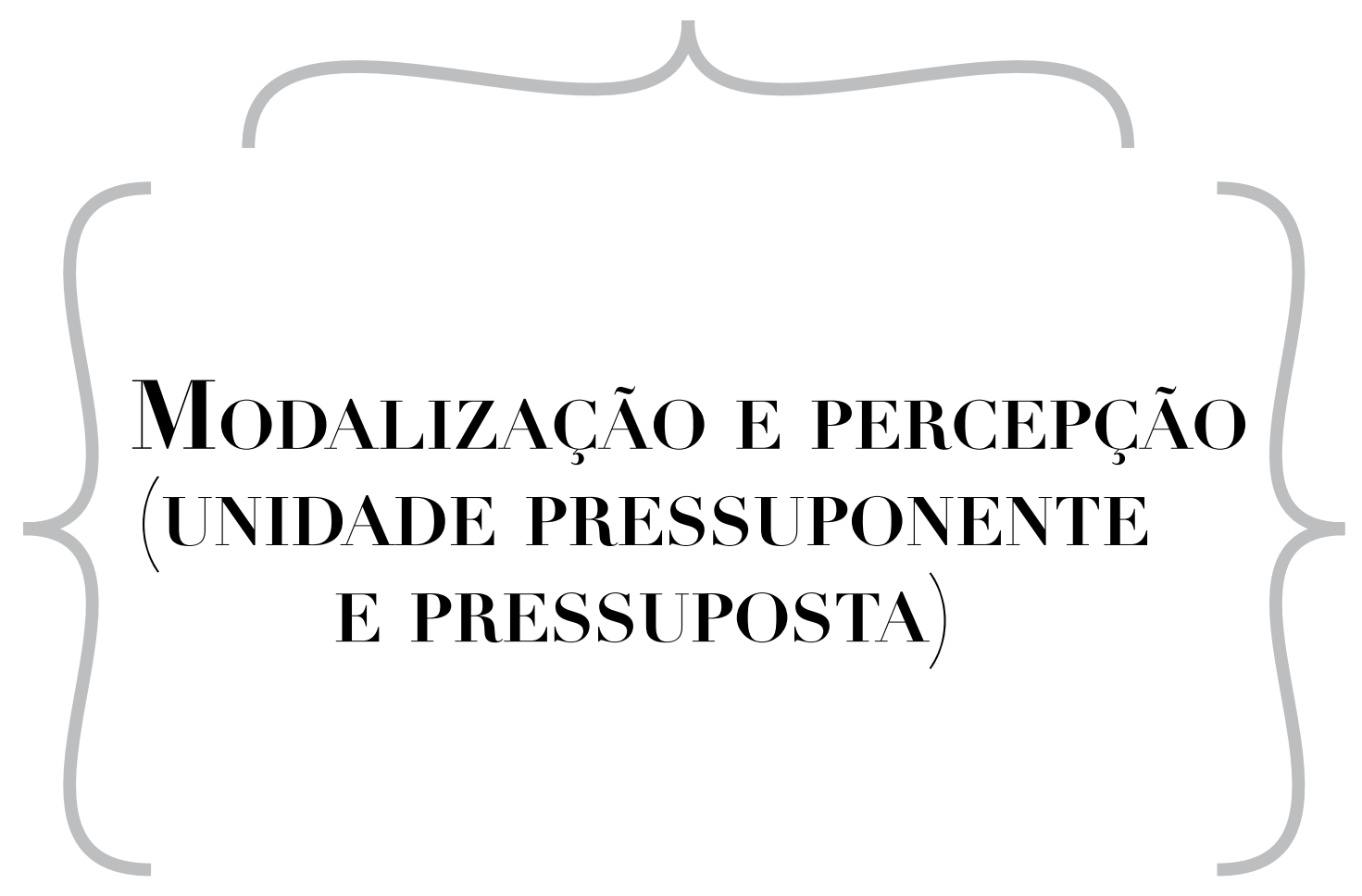




\subsection{Linguagem e categorização, modalização e percepção}

Como observamos no capítulo 1, mormente no item 1.4, "O horizonte de retrospecção teórico”, autores como Petitot (1983, p. 237 - 266) e Ricoeur (1983, p. 292 - 301), ao traçarem um horizonte teórico para a questão do CRER em semiótica, remontam à fenomenologia husserliana, não como uma herança ${ }^{34}$ absorvida pela ciência de Greimas, mas antes como um estágio historicamente significativo no tratamento desse tópico teórico e que se pareia à semiótica na medida em que igualmente tentou, formulando e empregando modelos, ferramentas e conceitos teóricos próprios, dar solução à questão.

Enquanto Ricoeur trata dessas teorias de forma mais apartada, apontando a filosofia kantiana, a fenomenologia husserliana e a semiótica textual como três possibilidades de redução frente à problemática do CRER, Petitot põe as teorias em relação mais próxima ao apontar a crítica de Husserl ao objetivismo da ciência positivista como estágio interventor entre Kant e a semiótica contemporânea. Como apontamos no capítulo 1, os paradigmas desse modo recuperados e ordenados por Petitot nos remetem às bases fenomenológicas da semiótica greimasiana, sobretudo a herança de Merleau-Ponty.

O alinhamento de Greimas ao pensamento merleau-pontyano é declaradojá nas páginas iniciais de Semântica Estrutural (1973 [1966]). A referência a MerleauPonty é feita no momento em que o semioticista estabelece sua primeira escolha epistemológica em relação à verificação da "onipresença da significação", que poderia levar a semântica à posição desconfortável de ser confundida com uma teoria do conhecimento. Para evitar isso, Greimas define que "os pressupostos epistemológicos da semântica devem ser tão pouco numerosos quanto possível” e se propõe a "considerar a percepção como o lugar não linguístico onde se situa a apreensão da significação" (1973, p. 15 - 16).

Ao colocar a apreensão como medida da significação, Greimas nos lembra que o sujeito que se modaliza de acordo com um CRER ou um SABER é forçosamente

34 Zilberberg (2006, p. 112), ao elencar as aquisições contemporâneas que a semiótica soube homogeneizar em sua teoria, dando-lhes ressonância e irradiação, aponta a fenomenologia hursserliana como a "herança da Alemanha". Contudo, ele problematiza-a em sua extensão e nacionalidade, destacando que o herdado limita-se às relações entre o pensamento de Maurice Merleau-Ponty e a semiótica greimasiana. Diante disso, porém, Zilberberg decide manter a designação visto que a obra do filósofo francês se proclama em estreita continuidade com a de Husserl. 
um sujeito da percepção de um fenômeno, qualquer que seja ele. Sendo assim, o uso de alguns conceitos da fenomenologia, sobretudo de Husserl e MerleauPonty, talvez se mostre produtivo para analisar o fazer-interpretativo do sujeito, no qual ele percebe um fenômeno - modaliza-se - e daí extrai uma significação.

Entendemos, porém, que um limite epistemológico se impõe ao propormos debater a percepção no âmbito de uma pesquisa desenvolvida sob o paradigma da semiótica enquanto ciência e disciplina que, por suas raízes saussurianas, assume como verdadeira e fundamental a noção de arbitrariedade do signo. Tal concepção, como nos apontam Greimas e Courtés (2008, p. 35), desempenhou um papel historicamente importante, que permitiu a Saussure estabelecer a autonomia da língua considerada como forma. Ao designar o caráter não motivado da relação que reúne o significante ao significado, Saussure elimina a questão do referente da reflexão científica - questão que se torna, ipso facto, informulável dentro de um estudo que se proponha a adotar a perspectiva semiótica em relação a seus objetos.

Em contrapartida, assistimos ao tournant phénomenologique pelo qual a semiótica passa hoje, movimento teórico que suscita questões de diversas ordens. Uma delas concerne justamente ao quanto de integridade a epistemologia própria à semiótica poderia manter a partir do momento em que a teoria se abre à abordagem fenomenológica do vivido, que em certa medida repõe a questão do referente no debate e afasta-se da postura epistêmica imanente, sustentáculo metodológico da ciência de Greimas.

Entre os teóricos que apontam ganhos no estreitamento de relações entre o ponto de vista semiótico e o fenomenológico, temos, por exemplo, o semiólogo Francesco Marsciani ${ }^{35}$. Ele defende ${ }^{36}$, entre outros aspectos, que há um problema de explicação na semiótica sobre de onde as categorias (diferenças), denominadas por alguns semioticistas como primitivos, vêm. A reflexão fenomenológica, então, poderia ajudar a entender o que há no nível mais profundo e abstrato do modelo do percurso gerativo de sentido, em uma busca pela categorização e pelo modo de surgimento das categorias. Além dele, temos também Fontanille, que vem apontando, sem muita hesitação, a fenomenologia como o caminho para o futuro

35 Universidade de Bolonha. Autor de obras como Tracciati di etnosemiotica (2007) e Ricerche semiotiche vol. I e II (2012) e Minima semiotica (2012).

$36 \mathrm{O}$ posicionamento de Marsciani apresentado aqui toma como base suas falas durante o minicurso "Entre semiótica e fenomenologia - as razões de uma releitura atual da fenomenologia", ministrado na FFLCH - USP entre 3 e 6 de junho de 2013, promovido pelo Grupo de Estudos Semióticos da USP. 
da semiótica em suas obras mais recentes, como Sémiotique du visible. Des mondes de lumière (1995), Sémiotique du corps (2004) e Soma et Séma: figures du corps (2004).

Diante desse contexto de propostas de interface e de intercruzamento de teorias, das quais ainda não podemos prever o resultado, e às quais Zilberberg se mantém refratário, abordamos a questão da percepção na análise apresentada no item seguinte deste capítulo. Ela se volta ao conto Funes, o memorioso, de Jorge Luis Borges, e se propõe a refletir sobre a noção da percepção em estreita ligação e, mais do que isso, em relação de pressuposição (como elemento pressuposto), com a modalização do sujeito. Nossa postura teórica sustenta a noção de que a percepção do mundo por parte do sujeito se dá inescapavelmente por meio de categorias linguageiras, ou seja, segundo determinadas categorias estabelecidas pela linguagem. Procuramos confinar a noção de qualquer etapa "anterior à linguagem" à abordagem própria da fenomenologia, resguardando a concepção semiótica que entende como simultâneos o momento de captação do fenômeno e de sobreposição da língua natural a ele. De modo geral, desejamos antes semiotizar a noção de percepção do que fenomenologizá-la. 


\subsection{Apreensão e significação em Funes, o memorioso}

Parler c'est oublier

(Husserl)

\subsubsection{Introdução}

O texto que constitui o objeto de análise do presente artigo foi escolhido não por outro motivo senão o fato de nos apresentar a fascinante e assombrosa figura de Irineu Funes, o memorioso. Fascinar-se e assombrar-se, duas atividades próprias do sujeito apassivado em parada da continuação, relacionam-se também ao modo de apreensão que Funes estabelece com o mundo discursivizado: a apreensão estética. Sujeito que de tudo se lembra e, portanto, teoricamente, em nossa visada semiótica, tudo apreende e tudo significa, ele é o personagem principal desse conto cujo acontecimento central é um diálogo. A conversa ocorre em 1887, num quarto escuro e úmido, no vilarejo sul-americano de Fray Bentos. Nela, Funes revela ao narrador o infalível, implacável e inquebrantável funcionamento de sua memória, transformada a partir do momento em que ele cai de um cavalo e se torna paralítico:

Disse-me que, antes daquela tarde em que o azulego o derrubou, fora o que são todos os cristãos: um cego, um surdo, um abobado, um desmemoriado. (...) Dezenove anos havia vivido como quem sonha: olhava sem ver, ouvia sem ouvir, esquecia-se de tudo, de quase tudo. Ao cair, perdeu o conhecimento; quando o recobrou, o presente era quase intolerável de tão rico e nítido, e também as lembranças mais antigas e triviais. Pouco depois constatou que estava aleijado. $\mathrm{O}$ fato mal o afetou. Discutiu (sentiu) que a imobilidade era um preço mínimo. Agora sua percepção e sua memória eram infalíveis. (Borges, 1975, p. 114) 
Nesse diálogo, o narrador serve de contraponto humano ao conhecimento sobre-humano e enciclopédico que Funes detém e continuamente acumula sobre o mundo, o que o leva a ser apontado como um "precursor dos super-homens" (Borges, 1975, p. 110). Enquanto el memorioso desafia a capacidade humana de percepção da realidade a partir da sua percepção, acumulando informações que chegam ao limite do intolerável em termos sensíveis (e armazenando absolutamente todas elas), o narrador, por sua vez, esquece-se, engana-se, tenta se apoiar em sua memória que, por ser tipicamente humana, às vezes lhe escapa, e acredita recordar-se do seu diálogo com Funes da seguinte maneira:

\subsection{2 "Recordo (creio)..."}

Recordo-o (não tenho direito de pronunciar esse verbo sagrado, somente um homem na Terra teve esse direito e esse homem morreu) com um escuro livro da paixão nas mãos, vendo-o como ninguém o viu, embora o avistasse do crepúsculo do dia até o da noite, toda uma vida. Recordo-o de rosto taciturno e indiático e singularmente distante, por trás do cigarro. Recordo (creio) suas mãos afiladas de trançador. (Borges, 1975, p. 109)

No seu primeiro encontro com Funes, em 1884, o narrador passeava a cavalo em Fray Bentos junto de seu primo, Bernardo Haedo. Eles voltavam da estância São Francisco quando encontram Funes e o primo lhe pergunta as horas. "Que horas são, Irineu?' Sem consultar o céu, sem deter-se, o outro respondeu: 'Faltam quatro minutos para as oito, jovem Bernardo João Francisco" (Borges, 1975, p. 110). Nos anos seguintes, o narrador fica afastado de Fray Bentos e veraneia em Montevidéu, retornando ao povoado em 1887. Ao perguntar pelo "cronométrico Funes", informam-lhe que este havia sido derrubado por um cavalo na estância de São Francisco e que ficara paralítico, sem esperança.

O narrador, então, comenta que à época empreendia um estudo metódico de latim: "Minha valise incluía o De viris ilustribus de Lhomond, o Thesaurus de Quicherat, os comentários de Júlio César e um volume ímpar de Naturalis historia de Plínio". Conta também que "tudo isso se propala no pequeno povoado" de Fray Bentos e logo Funes lhe escreve uma carta requerendo o empréstimo de 
algum dos volumes "acompanhado de um dicionário para a clara inteligência do texto original', porque ainda desconhecia o latim". A ideia de que o árduo latim poderia ser compreendido apenas com o auxílio de um dicionário espanta e diverte o narrador que, "para enganá-lo completamente", envia a Funes o Gradus ad Parnassum, de Quicherat, e a obra de Plínio.

Tempos depois, o narrador recebe um telegrama que o chama a Buenos Aires por causa do adoecimento de seu pai. Ao arrumar a mala para a viagem, ele percebe, porém, que Funes não havia lhe devolvido os volumes emprestados. Com a intenção de resgatá-los, dirige-se à casa de el memorioso. É lá que ocorre o diálogo com Funes, passagem central da narrativa, como já nos adverte o narrador: "Chego, agora, ao ponto mais difícil de minha narrativa. Esta (bom é que já saiba o leitor) não tem outro argumento que esse diálogo de há meio século" (Borges, 1975, p. 114). O encontro entre os dois conta com um pequeno preâmbulo ocorrido no pátio que dá acesso à peça onde se encontra Funes, no catre:

Ouvi logo a alta e zombeteira voz de Irineu. Essa voz falava em latim; essa voz (que vinha da treva) articulava com moroso deleite um discurso ou prece ou encantação. Ressoaram as sílabas romanas no pátio de terra; meu temor as acreditava indecifráveis, intermináveis; depois, no demorado diálogo daquela noite, soube que formavam o primeiro parágrafo do vigésimo quarto capítulo do livro sétimo da Naturalis historia. A matéria desse capítulo é a memória; as últimas palavras foram ut nihil non iisdem verbis redderetur auditum. ${ }^{37}$ (Borges, 1975, p. 113)

A noção de memória é algo não diretamente abordado e manipulado pela teoria semiótica em seus momentos iniciais. De fato, o termo não ocupa posição central nos modelos e teorias elaborados pela Escola de Paris (como a assumida pelos termos sujeito, objeto, ator, actante, figura, modalidade, programa, discurso etc.), tampouco constitui uma entrada no Dictionnaire raisonné de Greimas e Courtés. Desse modo, na ausência inicial de uma definição formal para "memória" que goze de estatuto semiótico, procedemos às definições acessórias, depreendidas, derivadas e inferidas a partir da definição de outros termos, esses sim em primeiro plano epistemológico. Isso se mostra possível visto que "memória" é uma noção forçosamente subsumida em conceitos semióticos 37 Para que tudo o que for ouvido seja representado pelas mesmas palavras (N. do E.) 
mais centrais e abrangentes na teoria, como o de percurso gerativo de sentido, o de programa narrativo e o de fazer missivo, que trabalham com uma lógica acumulativa de sucessão de elementos.

O percurso gerativo de sentido, por seu papel fulcral na análise da narrativa facultada pelo paradigma greimasiano, é tomado aqui como a noção de dimensão mais ampla entre as três. Composto por níveis extratificados de enriquecimento progressivo, nele talvez a ideia de acumulação seja mais saliente do que a de memorização de eventos, mas foi a primeira noção a que nossa intuição nos levou ao tentar rastrear a que conceitos semióticos se encontra aderida a concepção de memória. Destaca-se o caráter acumulativo do percurso visto que os níveis fundamental, narrativo e discursivo se encontram imbricados em dados textuais de qualquer natureza (verbais, gestuais, pictóricos etc.) a que tenhamos acesso. É apenas na análise que se revela o princípio de acumulação de tais níveis, em lógica sucessiva que tem sua cronologia sincopada pelo discurso.

Tal síncope parece ser desfeita nos programas narrativos, em que a cronologia dos eventos é então estendida em um eixo temporal e, à la Propp, uma manipulação é sucedida por uma ação, que é sucedida, por sua vez, por uma sanção; ou, à la Zilberberg, algo que me escapa por completo é depois apreendido e, finalmente, compreendido (em um típico programa de liquidação da falta). Desse modo, nos programas narrativos, tanto a acumulação como a memorização dos eventos são pertinentes, pois o sentido é construído por meio da sucessão de acontecimentos que devem ser memorizados até que a narrativa se complete. Em relação à questão, Zilberberg (2006, p. 130), ao retomar "a fórmula fulgurante de Bachelard: 'o depois explica o antes"” a fim de semiotizá-la, afirma que "todo pensamento em seu curso retoma a cadeia das pressuposições que o ordena".

O autor parte de tais apontamentos para introduzir a noção do fazer missivo, terceiro conceito semiótico a que recorremos para depreender informações sobre o papel da memória nos modelos semióticos. Entende-se que a noção de memória também se encontra subsumida no conceito de missividade, enquanto função composta pelos funtivos remissivo e emissivo, visto que "o fazer missivo discretiza o tempo" (2006, p. 135), permitindo à semiótica "domesticar" esse tempo. Assim, o remissivo e o emissivo se encontram na seguinte relação; "o tempo emissivo se move, oscila... começa quando o tempo remissivo se extenua e acaba" (2006, p. 135). O fazer emissivo está ligado ao ardor, ao arroubo, à continuidade, à extensidade, duração e apreensão do percurso. Em oposição, o fazer remissivo se refere à inibição, à parada, à intensidade e à stase. 
Conceito caro à análise ora proposta, a stase a que Zilberberg se refere avizinha-se da noção de apreensão estética em Greimas (2002, p. 33 - 34), que implica a imobilização momentânea do sujeito frente ao objeto estético no momento em que se dá a ruptura e a visão "ordinária" se torna "extraordinária". Para Zilberberg, a estetização "pode ser abordada como a ativação do objeto e passivação do sujeito - transformações acessíveis no efeito de sentido 'emoção estética'" (2006, p. 145). Ela constitui uma prática significante, que funciona em concorrência à etização. Defende-se aqui que Funes é um sujeito da stase, da apreensão estética, da parada da continuação, do assombro, e que sua prática significante em relação ao mundo é estetizante. Temos aí compreendido outro aspecto do modo de apreensão de Funes que, enquanto sujeito fictício, memoriza os acontecimentos, mas não atenua sua tonicidade. A singularidade e especificidade de qualquer experiência, para Funes, nunca se perdem, e esse é um mecanismo de funcionamento cognitivo que vai contra o percurso tensivo que o sujeito deve trilhar para guardar algo na memória, de acordo com o que apontam estudos mais recentes, como os de Tatit (2010), ao tentar compreender tensivamente o fenômeno da memorização.

Diante da ausência inicial de uma definição semiotizada da memória, então, é finalmente em um esquema de Zilberberg, junto a Fontanille (2001), que encontramos, aderida ao quadrado semiótico que representa o sistema da presença, essa pertinente possibilidade de tratamento teórico, de caráter tensivo, do processo de memorização. Em relação aos modos de presença do sujeito na narrativa, parte-se do pressuposto de que a perda da densidade da presença é uma condição para que algo seja memorizado. Assim, identificamos que, no percurso que vai da plenitude à vacuidade, o processo de memorização se encontra na fase da potencialização, como pode ser observado abaixo:

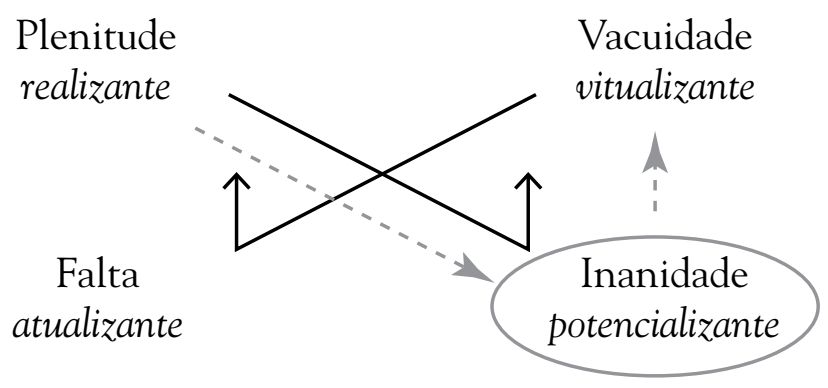

(Fontanille e Zilberberg, 2001, p. 134) 
De fato, a ausência de atenuação da tonicidade do acontecimento, que se dá na etapa da potencialização, relaciona-se diretamente com a condição de Funes, como propomos, enquanto sujeito da apreensão estética. Vejamos como isso pode ser depreendido a partir de trechos do conto.

\subsubsection{O cão das três e catorze}

Podemos começar a observar o modo de apreensão do mundo por Funes pelo seguinte excerto:

Sabia as formas das nuvens austrais do amanhecer do 30 de abril de 1882 e podia compará-las na lembrança com as listras de um livro espanhol encadernado que vira somente uma vez e com as linhas da espuma que um remo sulcou no rio Negro na véspera da Batalha do Quebracho. Essas lembranças não eram simples; cada imagem visual estava ligada a sensações musculares, térmicas, etc. (...) Uma circunferência num quadro-negro, um triângulo retângulo, um losango, são formas que podemos intuir plenamente; o mesmo acontecia a Irineu com as tumultuosas crinas de um potro, com uma ponta de gado numa coxilha, com o fogo irisante e com a inumerável cinza, com os muitos rostos de um morto num demorado velório. (Borges, 1975, p. 115)

Identificamos aqui, primeiramente, um sujeito cuja aguda percepção do mundo procede recortes sobre o dado sensível que inexistem para um ser humano comum, pois este os enxerga como um contínuo. Em decorrência disso, a linguagem se torna, para Funes, obsoleta: ambígua, imprecisa e insuficiente para dizer o mundo que ele percebe. Essa não coincidência entre a categorização realizada pela percepção de Funes e a categorização realizada pela linguagem sobre o "continuum amorfo" do mundo, se usarmos o termo Hjelmslev, será discutida mais detidamente adiante.

É importante observar que, malgrado Funes seja um sujeito que percebe e recorta seu objeto, não o alocamos na dêixis distensiva do quadrado da cognição 
proposto por Greimas, não o consideramos um sujeito ativo em relação a seu objeto e não o associamos à compreensão ou apreensão. Funes não é sujeito da conjunção com o saber, o que o alocaria na continuação. Em vez disso, ele é sujeito da não-conjunção. Isso se dá porque a sua percepção estridente solapa a capacidade humana de estabelecer relações de significação com o mundo e, por sua intermitência, o leva a um estado vertiginoso de sujeito apassivado diante de seus objetos. Funes os percebe, mas não consegue dizê-los. Sendo assim, alocamos Funes da dêixis contensiva, na parada da continuação, de acordo com o quadrado semiótico em sua versão tensiva:

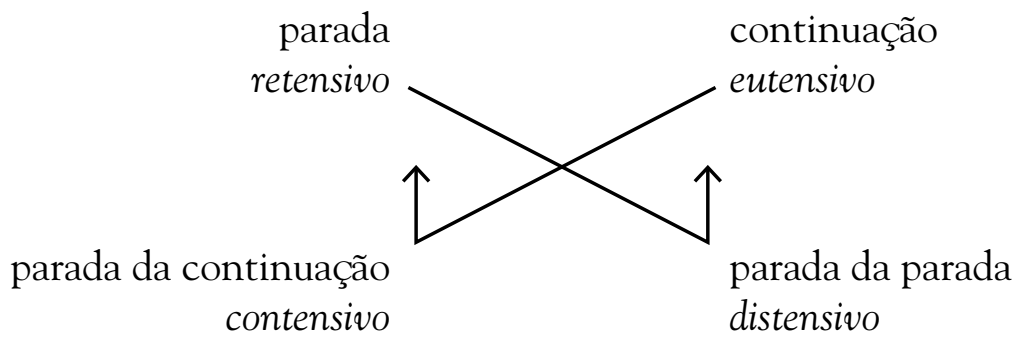

(Zilberberg, 2006, p. 161)

A sua passividade em relação aos objetos, condição do sujeito em espanto do fazer remissivo, da experiência pautada pela mediação do instante e pela transição imediata, é figurativizada já em sua condição de paralítico e discursivizada pela sua caracterização como "prisioneiro", "imóvel" e "também imóvel", como podemos observar no trecho:

Disseram-me que não se movia do catre, os olhos postos na figueira do fundo e numa teia de aranha (...) Observei-o duas vezes atrás da grade de ferro, que relembrava toscamente sua condição de eterno prisioneiro: uma, imóvel, com os olhos fechados; outra, também imóvel, absorto na contemplação de um oloroso galho de santonina. (Borges, 1975, p. 111, grifos nossos) 
O "espanto", aqui, é empregado no sentido facultado pelo quadrado da cognição proposto por Zilberberg:

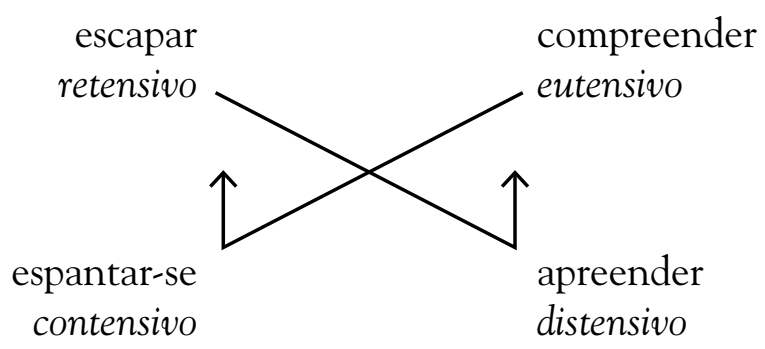

(Zilberberg, 2006, p. 162)

Funes é considerado um "sujeito apassivado" em não-conjunção conforme o seguinte percurso tensivo (depreendido do quadrado da cognição) também provido por Zilberberg:

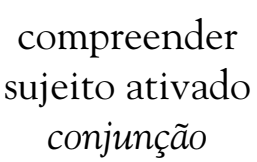

compreender conjunção

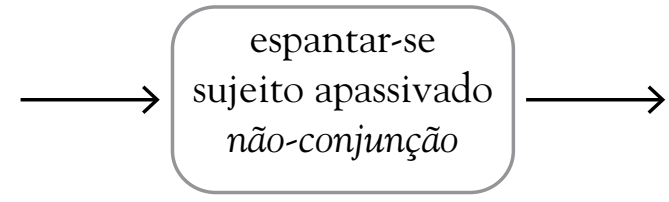

(Zilberberg, 2006, p. 163) escapar
objeto ativado
disjunção

Consideramos os objetos de Funes como estéticos com base no seguinte trecho: "Seu próprio rosto no espelho, suas próprias mãos, deslumbravam-no cada vez mais." (Borges, 1975, p. 117). Essa é uma postura que Funes sustenta de modo geral em relação a todos os seus objetos. A articulação, portanto, de um sujeito imobilizado (ou apassivado, como demonstramos ser Funes) frente a um objeto que se caracteriza como estético constitui a estrutura actancial (à qual já se aderem os conteúdos tímicos) de uma apreensão estética. $\mathrm{O}$ caráter disfórico que esse modo de apreensão assume na narrativa se deve ao fato de que todo e qualquer objeto, na percepção de Funes, é um objeto estético. A disforia aderida ao modo de apreensão estabelecido por Funes em relação aos fenômenos que o cercam é explicitada já no nome do personagem: Funes, que, ao fazer alusão ao termo "fúnebre" (em espanhol, a palavra é homóloga, "fúnebre"), antecipa-nos o fato de que o dom da memória prodigiosa recebido por Funes ao cair do cavalo é também, de forma irremediável, uma sentença de morte.

Isso se dá porque a estetização do cotidiano, do banal, do trivial, do corriqueiro, enfim, de absolutamente tudo sem qualquer hierarquização, configura um estado disfórico em relação à condição humana e leva Funes a habitar um mundo 
"vertiginoso" e "abarrotado", onde não há "senão pormenores, quase imediatos" (Borges, 1975, p. 118). O termo escolhido por Borges para descrever a sensação que esse sujeito experimenta no mundo discursivizado é o sufocamento:

Babilônia, Londres e Nova York sufocavam com feroz esplendor a imaginação dos homens; ninguém, em suas torres populosas ou em suas avenidas urgentes, sentiu o calor e a pressão de uma realidade tão infatigável como a que dia e noite convergia sobre o infeliz Irineu, em seu pobre arrabalde sul-americano. (Borges, 1975, p. 117)

O sufocamento, causado por uma oclusão espacial que incide sobre o sujeito, encontra-se em estreita relação com o fazer remissivo em que o sujeito se encontra engajado, visto que "toda remissão pode se configurar como cronopoiese, ‘implosão’ em relação ao tempo e como fechamento quanto ao espaço" (Zilberberg, 2006, p. 137). Em última instância, é tal sufocamento que causa a morte de Funes: nosso herói morre em 1889 de uma congestão pulmonar.

Outro aspecto que se deseja analisar é o fato de que, para Funes, sujeito dotado de "percepção e memória infalíveis", a linguagem se torna algo obsoleto, impreciso, ambíguo, vago e insuficiente para dizer o mundo que ele percebe. Isso é introduzido no conto por meio da seguinte passagem:

Locke, no século XVII, postulou (e reprovou) um idioma impossível no qual cada coisa individual, cada pedra, cada pássaro e cada ramo tivesse um nome próprio; Funes projetou certa vez um idioma análogo, mas o rejeitou por parecer-lhe demasiado geral, demasiado ambíguo. (Borges, 1975, p. 116)

Se partirmos do princípio de homologia proposto por Hjelmslev (2006 [1943], p. 53 - 64) entre os dois funtivos (expressão e conteúdo) que contraem a função semiótica, o descontentamento de Funes com a linguagem se dá pelo fato de que, ao tentar categorizar seu mundo por meio dela, ele se vê às voltas com uma função semiótica "disfuncional". A homologia entre os planos foi rompida, visto que sobram conteúdos que não encontram expressão na língua: 
Este (Funes), não esqueçamos, era quase incapaz de idéias gerais, platônicas. Não lhe custava compreender somente que o símbolo genérico cão abrangesse tantos indivíduos díspares de diversos tamanhos e diversa forma; aborrecia-o que o cão das três e catorze (visto de perfil) tivesse o mesmo nome que o cão das três e quinze (visto de frente). (Borges, 1975, p. 117)

\subsubsection{A linguagem antes da linguagem}

A dificuldade de Funes com a linguagem, porém, não se restringe à falta de correspondência entre conteúdos e expressões, mas estende-se a um princípio mais geral que rege o funcionamento da linguagem:

Tinha aprendido sem esforço o inglês, o francês, o português, o latim. Suspeito, entretanto, que não era muito capaz de pensar. Pensar é esquecer diferenças, é generalizar, abstrair. No abarrotado mundo de Funes não havia senão pormenores, quase imediatos. (Borges, 1975, p. 118, grifos nossos)

A definição dada para o "pensamento" pelo texto de Borges se aproxima da definição formulada pela semiótica sobre o próprio funcionamento da linguagem. Entre o dado sensível do real, com o qual o sujeito entra em contato a partir de seus sentidos, até sua a expressão linguageira, ocorre uma transformação (que generaliza, abstrai e categoriza o real), como nos aponta Husserl:

A representação intuitiva sobre a qual se constitui o fenômeno físico de uma palavra subsume uma modificação fenomenológica essencial quando seu objeto assume o valor de uma expressão. (Husserl, 1959, p. 10)

A volta da semiótica, ou tournant sémiologique, para os conceitos da fenomenologia e tese fenomenológica sobre a linguagem se mostra pertinente na análise de textos como Funes, o memorioso, onde se colocam em discussão 
as noções de apreensão do real e de significação (forçosamente posterior à apreensão do fenômeno, qualquer que seja ele), dada pela linguagem.

$\mathrm{O}$ que a fenomenologia tem a ver com a linguagem consiste naquilo que está antes da linguagem, que ainda não é linguagem, mas a funda, o que permite falar: a experiência antepredicativa. Desse modo, na abordagem metodológica da fenomenologia, para compreender a linguagem, é preciso sair dela.

Seria possível considerar, por exemplo, que Funes pôde ter a experiência antepredicativa do cão das três e catorze, visto de perfil, e a experiência do cão das três e quinze, visto de frente, mas que elas não chegaram a se tornar linguagem? Antes de responder à questão é preciso atentar para o fato de que, assumindo-se a experiência antepredicativa como o limiar inferior da linguagem, a percepção de Funes se dá já dentro determinadas categorias, que são linguageiras: cão, animal de pequeno a médio porte; três e quinze e três e catorze, ancoragens temporais que a linguagem permite realizar dentro de um período mais extenso, que seria o de um dia todo; e, finalmente, de perfil e de frente, recortes, ou categorizações, espaciais operados pela linguagem sobre o mundo.

Encontramo-nos, assim, em um campo onde a percepção disputa com a linguagem uma primazia: como ver sem nomear? É possível ver o que não está categorizado pela linguagem? Tais questões evidenciam a necessidade de se discutir o estatuto linguageiro da própria percepção, problema para o qual semiótica e fenomenologia ainda não encontraram solução.

O fato de que a palavra "cão" nomeie duas experiências distintas e, desse modo, intrigue e suscite a discordância de Funes, se dá porque, de acordo com Husserl, a significação é uma unidade na diversidade: é o momento ideal que a expressão busca. A linguagem tem a pretensão idealizante e universalizante de quando se pronuncie uma palavra (momento da expressão de acordo com a fenomenologia e domínio do significante na linguística) o conceito que venha à mente de todos seja o mesmo (significado).

Desse modo, falar é esquecer-se: esquecer-se das diferenças e das etapas que precedem o momento empírico da expressão (a saber: a experiência do objeto e sua significação). Como sabemos, Funes é um sujeito incapaz de se esquecer. Logo, é um sujeito incompatível com a própria linguagem. Os significados não lhe parecem precisos por abarcarem um número 
muito grande de "realidades" diferentes: mas esse é um princípio de funcionamento da própria linguagem, que une diferentes apreensões em uma mesma significação.

\subsubsection{Balanço da análise}

A análise ora realizada de Funes nos explicita que a dimensão humana da significação é dada pela apreensão do fenômeno. Tal constatação vai ao encontro da tomada de posição epistemológica de Greimas em Semântica Estrutural (1973, p.15) que, frente ao "caráter onipresente e multiforme" da significação, e, como já visto, para livrar a semântica do risco de ser confundida com uma "teoria do conhecimento", defende a noção da apreensão como medida da significação. Reconhecendo suas "preferências subjetivas pela teoria da percepção tal como foi anteriormente desenvolvida na França por Merleau-Ponty", o semioticista lituano propõe, então, considerar "com conhecimento de causa" a percepção como o lugar não linguístico onde se situa tal apreensão da significação.

De fato, essa passagem da obra greimasiana de 1966 ensejou e norteou parte de nossa análise sobre o conto de Borges. Por meio da investigação acerca de Funes, o memorioso, tentamos demonstrar que o uso de determinadas noções da fenomenologia, sobretudo de Husserl e Merleau-Ponty - este nominalmente citado por Greimas ao se remeter às bases fenomenológicas de sua teoria talvez se mostre pertinente para a análise do modo como o sujeito percebe o mundo discursivizado, que constitui um fenômeno, qualquer que seja a sua natureza, e, a partir disso, torna-se o sujeito de uma apreensão da qual é possível extrair uma significação.

O percurso de Funes também nos mostra que, para que o sujeito seja capaz de manipular a linguagem e circular em um mundo humano em que os sentidos (significações) são construídos exclusivamente através da linguagem, é preciso que sua memória o traia: que ele se esqueça e que seus sentidos, de alguma forma, o enganem. 


\section{COnchusão}

Uma análise que se propõe a abordar o CRER e o SABER no âmbito da teoria semiótica da Escola de Paris depara-se inicialmente com um desnível de definição teórica entre os termos. Quando nos voltamos às formulações que embasam a teoria greimasiana, rapidamente temos acesso a uma definição consagrada para o SABER em estreita relação com o esquema narrativo canônico: ele ocupa formalmente uma bem consolidada posição como modalidade atualizante, ao lado do PODER (também atualizante), do DEvER e do QUERER (virtualizantes), que juntos definem a competência do sujeito para a ação.

Por outro lado, o estatuto do CRER na teoria semiótica, como salienta Zilberberg (2006, p. 160), parece incerto. Ao mesmo tempo em que conta com verbete próprio no Dicionário de Greimas e Courtés, que salienta a importância e a centralidade da pesquisa relativa ao CRER para o futuro da disciplina, ele não é formalmente definido como uma modalidade na acepção oficial do termo; ao mesmo tempo em que compartilha com as demais modalidades a propriedade de reger um enunciado, diferencia-se delas pela capacidade de reger outro enunciado modal, como em CRER-QUERER, CRER-DEVER, CRER-PODER, e, finalmente, em CRER-SABER.

De fato, o CRER parece entrar oficialmente para o debate acerca do universo cognitivo pela via das modalidades epistêmicas, que consistem no CRER-ser (s1), CRER-não ser (s2), não CRER não ser $(\overline{\mathrm{s} 2})$ e não CRER-ser $(\overline{\mathrm{s} 1})$, os termos possíveis para a primeira etapa do juízo epistêmico do sujeito, concluído pela modalização veridictória que aí se justapõe, definindo pelo verdadeiro, o falso, o secreto ou o mentiroso. É desse modo que, segundo a teoria semiótica padrão, o CRER assumiria sua parte e função de modo a construir uma "verdade", ou, em termos semióticos, a forjar o parecer-verdadeiro. Esquematicamente, temos: 
MODALIDADES EPISTÊMICAS (na estrutura modal epistêmica)

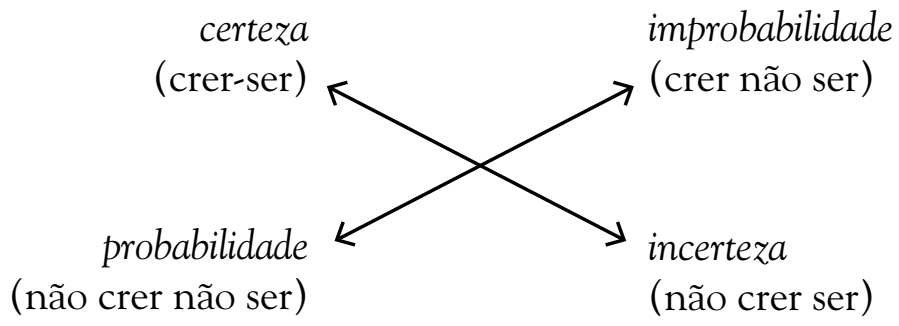

(Greimas e Courtés, 2008, p. 172)

\section{MODALIDADES VERIDICTÓRIAS}

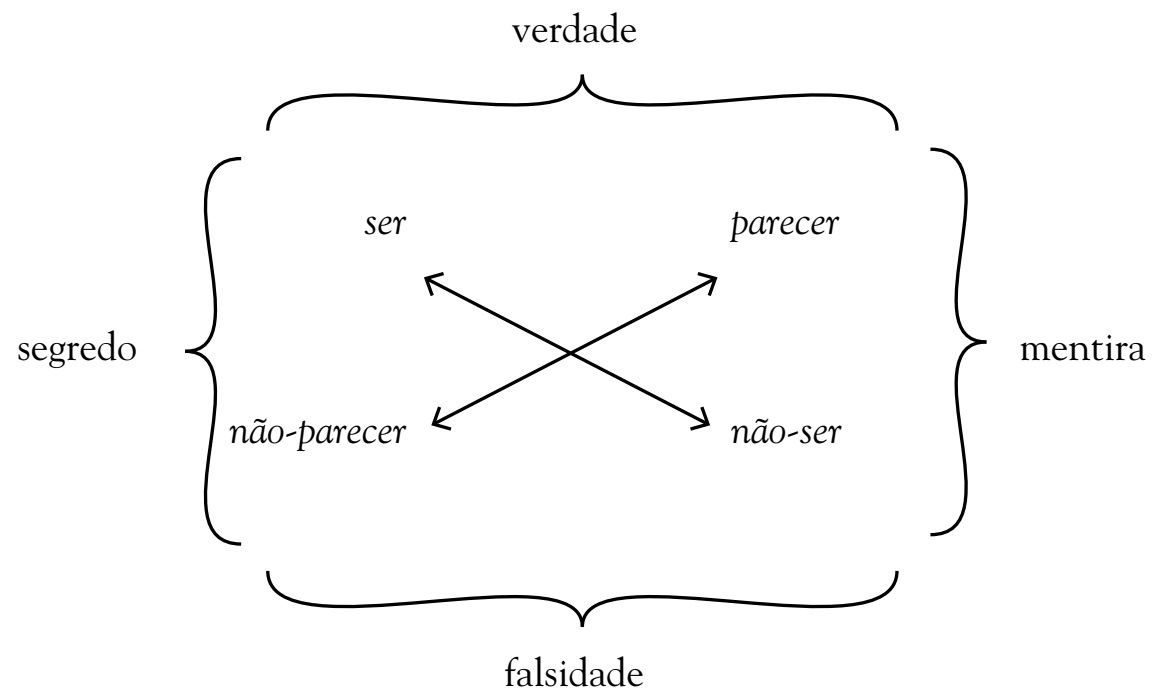

(Greimas e Courtés, 2008, p. 532)

Em relação às definições de base dessa maneira postuladas pela teoria semiótica para o CRER e o SABER, vimos Paul Ricoeur problematizar um primeiro aspecto que consideramos pertinente: a questão da passagem de um termo a outro dentro de um único e mesmo universo cognitivo:

A junção entre o contrato de veridicção (fazer persuasivo vs. fazer interpretativo) e a tábua das modalidades veridictórias parece ser feita por uma passagem não-tematizada do crer ao saber. A relação 
entre fazer persuasivo e fazer interpretativo é uma relação crer-ser verdadeiro. A relação entre verdade, falsidade, mentira e segredo é uma relação da alçada do saber-ser. (Ricoeur, 1983, p. 301)

Outro ponto da teoria questionado por Ricoeur ao final de seu artigo "La problématique de la croyance: opinion, assentiment, foi” (1983) alinhou-se à nossa tentativa de rastreamento da incidência da fé sobre a dimensão cognitiva: o autor questiona justamente "se o contrato de veridicção não é o último refúgio da fé, que parece ter desaparecido da teoria da veridicção" (1983, p. 301). De nossa parte, pudemos observar a noção de fé como elemento confinado e concentrado no momento de estabelecimento do contrato e abertura da comunicação, em que o mínimo de fidúcia intersubjetiva é exigido, e também presente na figura da aposta como definida por Fontanille (1982, p. 29), em que o sujeito, por meio de um ato de fé, abandona um universo de SABER que não lhe é mais relevante em direção à adesão via CRER.

Da mesma maneira, o CRER também pareceu ser alvo desse tipo de confinamento no modelo teórico semiótico. Como já ressaltamos em diversos pontos desta dissertação, a ação do CRER é concebida, talvez preliminarmente no curso do desenvolvimento da teoria, como uma interferência modal pontual e concentrada: (i) no momento da instauração da comunicação entre um destinador e um destinatário, para a qual o CRER configura o "prelúdio" fulcral, conforme vimos em Greimas (1983, p. 123); (ii) na etapa de manipulação fiduciária do esquema narrativo canônico, em que o destinador aciona estratégias persuasivas que visam a fazer o destinatário CRER; (iii) no momento de sanção epistêmica por parte do destinatário, por ocasião do encerramento da narrativa; e, finalmente, (iv) na instância da enunciação, em que o CRER concentra-se em seu papel precedente.

Fazemos a ressalva, porém, de que esses "locais" de incidência relevante do CRER, apesar de descritos como distintos, por vezes configuram um mesmo ponto no fenômeno da comunicação humana, diferenciados apenas pela tomada de posição do analista: ao abordar o CRER na instância da enunciação, pode-se considerá-lo como precedente; ao enquadrá-lo no âmbito da comunicação, o CRER pode ser definido como modalidade instauradora da cota de fidúcia mínima para que a relação entre destinador e destinatário se estabeleça. 
Uma tendência geral das reflexões teóricas de que nos servimos para empreender este estudo é, em primeiro lugar, o apagamento ou a não abordagem da função do CRER enquanto dispositivo semiótico capaz de modalizar um enunciado já modal. Tomar como inerte a ação do CRER em arranjos do tipo CRER-SABER, por exemplo, de certo modo interdita a abordagem e compreensão da atividade cognitiva do sujeito, que, como defendemos e procuramos demonstrar ao longo do capítulo 3, não pode prescindir do CRER para dotar o mundo de sentido.

Um trecho de exceção a essa postura geral pôde ser encontrado em Razão e poética do sentido. Diante da possibilidade de existência de arranjos como CRERQUERER e CRER-DEVER, Zilberberg (2006, p. 160) indaga: “afinal, o dever e o querer não pressupõem um crer, ou seja, uma junção com o valor do valor? Para levar a bom termo um empreendimento, o senso comum não recomenda 'acreditar nele'?". O afastamento do modelo teórico em relação a essa propriedade do CRER parece-nos ter contribuído, em alguma medida, para o desaparecimento da noção de fé na teoria - o que tentamos reverter aqui - e também para a criação de redutos em que a ação do CRER está prevista, e encontra acolhimento e descrição teóricos, no lugar da concepção de sua ação como intermitente ao longo de todo o percurso gerativo de sentido.

Uma segunda tendência teórica generalizada, da qual nos valemos desde o título desta dissertação, é o tratamento do CRER e SABER, ambos, como duas modalidades em igualdade de direitos e implicações teóricas como tais, malgrado o CRER não se encontrar formalmente definido como uma das modalidades que formam a competência do sujeito para a ação, mas como uma espécie de raiz geradora dos quatro termos alocados no quadrado semiótico das modalidades epistêmicas - desnível em definição teórica apontado no início desta conclusão.

De fato, a equiparação dos termos enquanto modalidades, que é paradigmática na teoria desde "Le savoir et le croire: un seul univers cognitif" (1983), de Greimas, mostra-se produtiva na medida em que gera ferramentas e oferece subsídios para a análise do funcionamento do universo cognitivo do sujeito. Apesar de defendermos a semiótica do contínuo como aquela capaz de captar e compreender a ação intermitente do CRER nas narrativas, em oposição à visão compartimentada referente à incidência dessa modalidade nos discursos, trabalhamos de forma majoritária, ao longo das análises apresentadas nos capítulos 2 e 3, com ferramentas provindas de reflexões teóricas que discretizaram o universo cognitivo no sentido de estabelecer, no interior dele, um domínio para o CRER E outro para o SABER. 
Foi isso que encontramos, por exemplo, nas distinções paradigmáticas concernentes aos termos como postuladas por Greimas (1983), e retomadas por Fontanille (1987, p. 55), que as considera “incontornáveis", e no estabelecimento de dois universos de adequação cognitiva, um referente ao CRER e o outro, ao SABER, cada qual com suas operações cognitivas próprias, cujo funcionamento se dá sob a tônica de um dever-ser no primeiro caso, e de um poder-ser no segundo, como defendido e demonstrado por Fontanille "Un point de vue sur 'croire' et 'savoir' - Les deux systèmes de l'adéquation cognitive” (1982).

Foi por meio da aplicação desse modelo teórico de 1982 de Fontanille, que traz consigo a noção de percurso transgressivo (a passagem do sistema do CRER ao sistema do SABER, e vice-versa), que pudemos levar a termo a análise da cena do longa-metragem Doubt (2008) apresentada no capítulo 2 e também abordar e descrever a gramática modal que subjaz aos movimentos cognitivos dos sujeitos discursivamente construídos no poema analisado ao longo do capítulo 3. Ao adotar como ponto de partida de suas reflexões os Diálogos de Platão, Fontanille alinha as elaborações teóricas contidas em seu artigo de 1982, desde sua origem, a importantes aspectos da argumentação e da persuasão, movimento que a teoria semiótica tem ultimamente realizado ao se voltar com mais atenção às questões retóricas.

Procuramos, entretanto, matizar nosso protocolo de análise desses dois objetos com elementos e ferramentas próprios da semiótica tensiva, recolhidas sobretudo junto às reflexões de Fontanille e Zilbelberg (2001) e Zilberberg (2006). Foi apenas graças a esta abordagem gradual do universo cognitivo, que permite tanto pensar em cifras tensivas (constituídas por um valor de intensidade e outro de extensidade) associadas a uma modalidade ou operação modal quanto analisar parâmetros como a tonicidade, o ritmo e o andamento da relação instaurada entre o sujeito e seus objetos cognitivos, que logramos identificar e demonstrar a existência de altas e baixas cifras tensivas aderidas tanto ao universo do CRER quanto do SABER e diferenciar sujeitos cognitivos como o que crê-saber, o que sabe mal e o que sabe pouco.

A perspectiva de pendor categórico de Fontanille (1982), porém, não nos pareceu dispensável ou superada ao menos no contexto de um estudo inicial acerca das modalidades CRER e SABER. De fato, ao longo da confecção desta dissertação, sentimos a necessidade de nos ater centralmente ao modelo de Fontanille (1982) para visualizar e compreender, talvez de forma mais didática, o jogo modal que sustenta o fazer interpretativo subjetivo e que funciona, para o 
autor, por meio de atualizações e virtualizações de dois sistemas de adequação cognitiva que pressupõem um único sujeito cognitivo. Não obstante, diante das conclusões relativas à consistência e ao modo de operação do universo cognitivo às quais nos foi possível chegar através desse modelo, acabamos por fazer a defesa, no capítulo 3, da semiótica do contínuo, e de nos servir de sua abordagem e ferramentas para que as análises aqui apresentadas pudessem ganhar em alcance e em profundidade.

Se, partindo das formulações de Fontanille (1982) e Greimas (1983) sobre a dimensão cognitiva, identificamos a necessidade de recorrer à abordagem tensiva para unir à modalização do sujeito também os seus desdobramentos tensivos, e daí extrair resultados para nossas análises, a questão parece já estar resolvida no enfoque apresentado por Zilberberg (2006) sobre o tema. A solução de Zilberberg em seu modelo para a atividade cognitiva ultrapassa a distinção de base em que ancoramos este estudo desde o início: a diferenciação entre os termos CRER E SABER.

Em seu "quadrado da cognição", o CRER e o SABER não se encontram discretizados, como unidades individualizadas que detêm fronteiras teóricas. $\mathrm{O}$ que se apresenta é um contínuo referente ao universo cognitivo, que parece unir essas duas instâncias em uma abordagem que prioriza captar e representar graficamente o andamento e a velocidade, esta, sim, o germe fundamental na produção de sentidos, na relação entre o sujeito e o objeto cognitivo.

Apesar de a distinção entre as modalidades não se impor em primeiro plano nesse modelo zilberbergiano, encontram-se nele aderidas as oscilações tensivas que constatamos e defendemos como características do fazer interpretativo do sujeito que, para conhecer algo sobre seu mundo, forçosamente deve se modalizar de acordo com um CRER, depois com um SABER, depois com um CRER, em um arranjo essencialmente dinâmico e que assume contorno cíclico.

Zilberberg isenta-se de tornar descontínuos os terrenos do CRER e do SABER no interior da dimensão cognitiva, sem deixar por isso de dar conta, de forma peremptória para a semiótica tensiva, dos movimentos cognitivos compreendidos por Fontanille (1982) como internos a cada um dos sistemas (percursos regressivos e progressivos) e de travessia de um sistema a outro (em percurso transgressivo do CRER ao SABER ou do SABER aO CRER) - movimentos que defendemos e demonstramos, no capítulo 2, ocorrerem em companhia de oscilações tensivas, produtoras de efeitos de sentido importantes no interior 
das narrativas. A estrutura final que constitui o que Zilberberg define como o "quadrado da cognição", como já apresentada no capítulo 1 desta dissertação, é a seguinte:

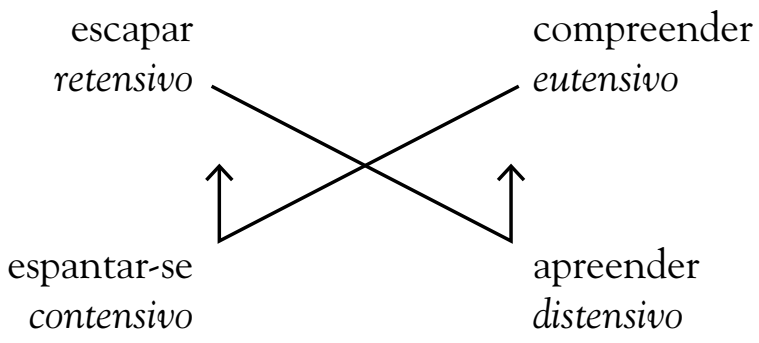

(Zilberberg, 2006, p. 162)

A partir dessa solução conceitual e gráfica, Zilberberg afasta-se do percurso previsto pela semiótica clássica para o sujeito que busca conhecer seu objeto: trajeto que conta com uma modalização epistêmica seguida de uma modalização veridictória e é considerado por ele problemático, mas nem por isso desencorajador da investigação relativa à consistência semiótica da atividade cognitiva:

Em ambos os casos (da definição de Greimas, que reduz o crer à confiança, e de Fontanille, que distingue dois sistemas e reencontra a posição de Greimas), o saber se encontra como que em "curtocircuito", como se a modalização epistêmica privasse a atividade cognitiva de seu conteúdo operatório próprio. É decerto delicado caracterizar a atividade cognitiva, mas essa dificuldade não deve nos levar a considerar que tal atividade cognitiva seja, em si própria, vã, desinteressante, residual. (Zilberberg, 2006, p. 161)

O modelo de Zilberberg parece livrar o SABER de sua subserviência ao CRER imposta por dois aspectos encontrados na teoria padrão: pela precedência da modalização epistêmica em relação à veridictória no percurso de construção de uma "verdade", ou, em termos semióticos, de um parecer-verdadeiro, e pela própria precedência que o CRER assume no âmbito da enunciação, segundo a qual, como ressalta Fontanille (1987, p. 55): "nenhum saber saberia ser enunciado sem ser previamente modalizado por um julgamento epistêmico (de certeza, de improbabilidade, etc.), o que o transforma, ipso facto, em crer". 
Assim, observamos que não à toa o "quadrado da cognição", bem como suas decorrências e implicações teóricas, mostrou-se especialmente pertinente e produtivo enquanto ferramenta em nossa análise de Funes, o memorioso, apresentada ao longo do capítulo 4 desta dissertação. Nela, nos debruçamos sobre a atividade cognitiva de um sujeito de um SABER "puro": um SABER exacerbado a ponto de se tornar pejorativo, e, além disso, um SABER que domina continuamente a atividade cognitiva do sujeito, que se mostra imune e livre a qualquer incidência do CRER e, por isso, é forçosamente ficcional. Na relação de Funes com o mundo que o cerca, teríamos a já conjecturada por Fontanille $(1982$, p. 11) e $(1987$, p. 56 - 57) relação imediata entre sujeito e objeto, em que o apagamento do actante destinador eliminaria, a reboque, a presença do CRER do fazer interpretativo. O sujeito, então, modalizado de acordo com um SABER, travaria contato direto com seus objetos cognitivos, avizinhando-se, de forma mais promissora, da realidade última sobre as coisas que o cercam.

Essa é uma hipótese plausível, porém, em nosso ponto de vista, fugidia. Quando nos voltamos à estrutura proposta para a cognição por Zilberberg (2006, p. 162), constatamos que ela reafirma o caráter inexoravelmente cíclico que a atividade cognitiva deve assumir: é pouco provável que o sujeito se aloque seja na parada da parada (apreensão), seja na continuação (compreensão), e ali permaneça indefinidamente, a menos que o princípio elementar que rege o desenrolar de sua narrativa, ou de sua vida, cesse. No caso de uma narrativa ficcional, esse estancamento pode ser explorado por gerar efeitos de sentido não convencionais ou usuais, e por isso literariamente ricos e interessantes, como encontramos no conto Funes, o memorioso.

A ação intermitente do CRER sobre os movimentos cognitivos do sujeito parece ser inescapável em um mundo construído pela linguagem e apreendido pelo sujeito por meio de categorias linguageiras. Essa modalidade, e assim procuramos demonstrar por meio das reflexões tecidas ao longo desta dissertação, inegavelmente tem a sua contribuição para a construção dos sentidos e dos saberes humanos. De fato, a dinamicidade requerida para o processo de produção de conhecimento parece impor ao sujeito uma circulação contínua e cíclica entre os dois tipos de racionalidade: o CRER e o SABER.

Achamos oportuno, a esta altura da dissertação, em que encerramos nosso texto por meio da apresentação de algumas reflexões de caráter conclusivo, dar respostaà nossa pergunta de partida, questão que desengatilhou o desenvolvimento deste trabalho: seria possível ao sujeito efetivamente saber algo sobre o mundo? 
Parece-nos possível SABER, mas, para aí chegar, é preciso que o sujeito se valha da contribuição indelével do CRER para a construção do conhecimento humano. Defendemos ainda que o conteúdo do saber, o tomado como verdadeiro, seja ele de foro íntimo ou de caráter institucionalizado como o saber produzido por uma ciência, é essencialmente e sempre discursivo, ou seja, aquele dotado de sentido para o ser humano.

A investigação desse tema, seja por sua natureza ampla ou pelas questões que foram levantadas ao longo desta dissertação sem, por isso, terem encontrado resoluções definitivas, comporta ainda espaço para extensa elucubração teórica. Encerramos nosso trabalho com uma breve citação que se alinha e corrobora o aspecto geral das conclusões às quais, por meio das formulações e ferramentas teóricas providas pela semiótica da Escola de Paris de que nos servimos, os objetos que elegemos para análise, a metodologia e a postura epistemológica adotadas, nos foi possível chegar:

Talvez uma das questões mais importantes e difíceis para o semioticista seja essa aceitação do conhecimento como produção de sentido - por mais que, como seres humanos, sempre queiramos respostas ontológicas, como semioticistas temos que admitir que estas respostas não estão ao nosso alcance. (Lopes, 2012, p. 16) 


\section{REFERÊNCIAS BIBLIOGRÁFICAS}

ALEXANDRESCU, Sorin [1976]. Sur les modalités "croire" et "savoir". Langages $\mathrm{n}^{\circ} 43$, p. $19-27$.

. [1983] Saying and (Dis)believing. In: PARRET, H. (Org.) De la croyance. Approches épistémologiques et sémiotiques. Berlim-Nova York: Walter de Gruyter Verlag, p. 16 - 30.

BEIVIDAS, Waldir [2011]. A dimensão do afeto em Semiótica: entre Fenomenologia e Semiologia. In: Marchezan, R.; Cortina, A.; Baquião, R. C. (Org.). A abordagem dos afetos na semiótica. São Carlos: Pedro e João Editores, 2011, v. 1, p. $11-32$.

. [2003] Corpo, semiose, paixão e pulsão. Semiótica e metapsicologia.

Perfiles Semióticos, Mérida - Venezuela, v. 1, nº 1, p. 43 - 61.

. [2001] Inconsciente et verbum: psicanálise, semiótica, ciência, estrutura. São Paulo: Humanitas FFLCH/ USP.

- [2011] Sémiotique du vécu (l'affect). Sémiologie ou phénoménologie? In:

Hénault, A.; Bertrand, D.; Bordron, J-F. (Org.). Sémiotique: le sens, le sensible, le réel. Paris: PUF, 2011, v. 1, p. 1 - 18.

BENVENISTE, Émile [1966]. Problèmes de linguistique générale I. Paris: Gallimard.

BERRENDONNER, Alain [1981]. Éléments de pragmatique linguistique. Paris: Les Éditions de Minuit.

BORGES, Jorge Luis [1944]. Funes, o memorioso. In: Ficções. Trad. Carlos Nejar. São Paulo: Círculo do Livro, p. 109 - 118, 1975.

COQUET, Jean-Claude [1983]. Les discours de la véridiction. In: PARRET, H. 
(Org.) De la croyance. Approches épistémologiques et sémiotiques. Berlim-Nova York: Walter de Gruyter Verlag, p. 57 - 84.

CRUZ, Dilson Ferreira da [2008]. Algumas considerações sobre o crer e o saber. Estudos Semióticos. [online] Disponível na internet via: http://www.fflch.usp. br/dl/semiotica/es. Editor Peter Dietrich. Número 4, São Paulo. Acesso em 11/11/2011

- [2006] O éthos do enunciador dos romances de Machado de Assis: uma abordagem semiótica. Tese de doutorado. Apresentada ao Departamento de Linguística da Faculdade de Filosofia, Letras e Ciências Humanas da Universidade de São Paulo. Orientador: Izidoro Blikstein.

DISCINI, Norma [2010]. Da presença sensível. Cadernos de Semiótica Aplicada. Vol. $8 \mathrm{n}^{\circ}$ 2. Disponível em: http://seer.fclar.unesp.br/casa. Acesso em 8/8/2011.

DÚVIDA. Doubt. Direção de John Patrick Shanley. Goodspeed Productions. EUA: 2008. São Paulo: Buena Vista Home Entertainment, 2009. DVD (104 min.), colorido.

FONTANILLE, Jacques [2004]. "A semiótica do corpo: entre psicanálise, fenomenologia e antropologia”. In: CORTINA, A.; MARCHEZAN, R. C. (Org.). Razões e sensibilidades: a semiótica em foco. Araraquara: Laboratório Editorial FCL/UNESP, 2004, p. 89 - 112.

- [1987] Le savoir partagé - Sémiotique et théorie de la connaissance chez Marcel Proust. Paris/Amsterdam/Filadélfia: Editions Hadès-Benjamins.

. [2006] Pratiques sémiotiques:immanence etpertinence, efficienceetoptimisation. Nouveaux actes sémiotiques, $\mathrm{n}^{\circ}$ 104, 105, 106. Limoges: Pulim.

- 1999] Semiótica do discurso. Trad. Jean Cristtus Portela. São Paulo: Contexto, 2007.

. [1995] Sémiotique du visible. Des mondes de lumière. Paris: PUF.

. [2004] Soma et Séma. Figures du corps. Paris: Maisonneuve \& Larose. 
. [1982] Un point de vue sur 'croire' et 'savoir', Actes sémiotiques, IV, 31, p. $5-31$.

; ZILBERBERG, Claude [1998]. Tensão e significação. Trad. Ivã Carlos Lopes, Luiz Tatit e Waldir Beividas. São Paulo: Discurso Editorial/ Humanitas, 2001.

GENINASCA, Jacques [1983]. Composantes thymiques et prédicatives du croire. In: PARRET, H. (Org.) De la croyance. Approches épistémologiques et sémiotiques. Berlim-Nova York: Walter de Gruyter Verlag, p. 111 - 145.

GREIMAS, Algirdas Julien [1987]. Da imperfeição. Trad. Ana Cláudia de Oliveira. São Paulo: Hacker Editores, 2002.

. [1983] Du sens II. Essais sémiotiques. Paris: Seuil.

. [1976] Pour une théorie des modalités. Langages n 43, p. 90 - 107.

- [1966] Semântica estrutural. Trad. Izidoro Blikstein e Haquira Osakabe. São Paulo: Cultrix, 1973.

; COURTÉS, Joseph [1979]. Dicionário de Semiótica. Trad. Alceu Dias Lima, Diana Luz Pessoa de Barros, Eduardo Penuela Canizal, Edward Lopes, Ignacio Assis da Silva, Maria José Castagnetti Sombra, Tieko Yamaguchi Miyazaki. São Paulo: Contexto, 2008.

HJELMSLEV, Louis [1972]. La catégorie des cas. Munique: Wilhelm Fink Verlag. - [1943] Prolegômenos a uma teoria da linguagem. Trad. Teixeira Coelho Netto. São Paulo: Perspectiva, 2006.

HOUAISS, Antônio [2008]. Grande dicionário Houaiss da língua portuguesa. Instituto Antônio Houaiss, Rio de Janeiro: Objetiva.

HUSSERL, Edmund [1959]. Recherches logiques II. Paris: PUF.

LANDOWSKI, Eric [1983]. "Sincérité, confiance et intersubjectivité". In: 
PARRET, H. (Org.) De la croyance. Approches épistémologiques et sémiotiques. Berlim-Nova York: Walter de Gruyter Verlag, p. 161 - 171.

LOPES, Ivã Carlos [2004]. Esquematização da modalidade epistêmica. In: Cortina, Arnaldo; Marchezan, Renata. (Org.). Razões e sensibilidades: a semiótica em foco. $1^{\mathrm{a}}$ ed. Araraquara: Laboratório Editorial FCL/UNESP; São Paulo: Cultura Acadêmica Editora. v. 1, p. 51 - 65.

. [2012] "Semiótica e morfodinâmica. Uma busca e suas vicissitudes". In: Anais - Seminários Teóricos Interdisciplinares do SEMIOTEC - I STIS. Novembro/2012. Disponível em: www.periodicos.letras.ufmg.br/index.php/ stis/issue/view/120. Acesso em 14/8/2013.

; BEIVIDAS, Waldir [2009]. Argumentação e Persuasão: Tensão entre Crer e Saber em "Famigerado", de Guimarães Rosa. Revista Alfa. 53 (2), p. 443 - 455.

; BEIVIDAS, Waldir [2007]. Veridicção, persuasão, argumentação: notas numa perspectiva semiótica. Todas as Letras (São Paulo). Volume 9, nº 1, p. 32 - 41.

MARIN, Louis [1983]. Secret, dissimulation: les conditions rhétoriques de la croyance. In: PARRET, H. (Org.) De la croyance. Approches épistémologiques et sémiotiques. Berlim-Nova York: Walter de Gruyter Verlag, p. 203 - 215.

MARRONE, Gianfranco [2000]. "Le corps de la nouvelle: trois études sur identités et styles dans les journaux télévisés italiens". Nouveaux Actes Sémiotiques 68, 69, 70. Limoges: Pulim.

MAUPASSANT, Guy de [1887]. "Horla". In: Bola de Sebo e outros contos. Trad. Pietro Nassetti. São Paulo: Martin Claret, 2003, p. 167 - 188.

MOIGNET, Gérard [1970]. "Personne humaine et personne d'univers...". In: Travaux de linguistique et littérature I, Strasbourg, p. 193, 196 e 198.

OLIVEIRA, Ana Cláudia; LANDOWSKI, Eric. (Eds.). [1995] Do inteligível ao sensivel: em torno da obra de Algirdas-Julien Greimas. São Paulo: EDUC.

PARRET, Herman [1983]. Common sense and basic beliefs: from certainty to hapiness. In: PARRET, H. (Org.) De la croyance. Approches épistémologiques et sémiotiques. Berlim-Nova York: Walter de Gruyter Verlag, p. 216 - 228. 
PETITOT, Jean [1983]. Choix et croyance: vers une logique de l’idéal. In: PARRET, H. (Org.) De la croyance. Approches épistémologiques et sémiotiques. Berlim-Nova York: Walter de Gruyter Verlag, p. 237 - 266.

PORTELA, Jean Cristtus [2006]. Conversations avec Jacques Fontanille. Alfa, São Paulo, v. 50, n. 1, p. 159 - 186.

POTTIER, Bernard [1983]. Le croire dans une perspective sémio-linguistique dynamique. In: PARRET, H. (Org.) De la croyance. Approches épistémologiques et sémiotiques. Berlim-Nova York: Walter de Gruyter Verlag, p. 267 - 273.

. [1987] Théorie et analyse en linguistique. Paris: Hachette.

RAMOS-SILVA, Sueli [2007]. O discurso de divulgação religiosa materializado por meio de diferentes gêneros: dois éthé, duas construções do Céu e da Terra. Dissertação de Mestrado. Apresentada à Faculdade de Filosofia, Letras e Ciências Humanas da Universidade de São Paulo. Orientadora: Norma Discini de Campos.

RICOEUR, Paul [1983]. "La problématique de la croyance: opinion, assentiment, foi”. In: PARRET, H. (Org.) De la croyance. Approches épistémologiques et sémiotiques. Berlim-Nova York: Walter de Gruyter Verlag, p. 292 - 301.

ROSA, João Guimarães [1988]. "Famigerado". In: Primeiras Estórias. Rio de Janeiro: Editora Nova Fronteira, p. 13 - 17.

SAUSSURE, Ferdinand de [1969]. Curso de linguística geral. Trad. Antônio Chelini, João Paulo Paes e Izidoro Blikstein. São Paulo: Cultrix, 2004.

SHAKESPEARE, William [2005]. The complete sonnets and poems. Ed. Colin Burrow. Oxford: Oxford University Press.

TATIT, Luiz [2010]. Semiótica à luz de Guimarães Rosa. São Paulo: Ateliê Editorial.

TOLSTÓI, Leon [1877]. Ana Karênina. Trad. João Gaspar Simões. São Paulo: Abril, 1971.

ZILBERBERG, Claude [1988]. Razão e poética do sentido. Trad. Ivã Carlos Lopes, Luiz Tatit e Waldir Beividas. São Paulo: Edusp, 2006. 
Anexo A:

Reprodução do corpus

Transcrição da cena do longa-metragem Doubt (4'27” a 8'30”), que contém o sermão do padre Flynn.

\section{Padre Flynn}

O que você faz quando não tem certeza? Este é o tema do meu sermão de hoje. No ano passado, quando o presidente Kennedy foi assassinado ${ }^{38}$, quem entre nós não teve a experiência da mais profunda desorientação? Desespero? Qual caminho seguir? E agora? O que digo aos meus filhos? O que digo para mim mesmo? Houve um tempo em que as pessoas ficavam sentadas juntas, unidas por um sentimento comum de desesperança.

Mas pense nisso: seu vínculo com o seu companheiro foi o seu desespero. Foi uma experiência pública. Foi horrível, mas nós estávamos juntos nisso. O quanto pior seria, então, para o homem solitário, a mulher solitária, serem atingidos por uma calamidade privada? "Ninguém sabe que eu estou doente"; "Ninguém sabe que eu perdi meu último verdadeiro amigo"; "Ninguém sabe que eu fiz algo errado". Imaginem o isolamento. Você vê o mundo através de uma janela. Em um dos lados do vidro: pessoas felizes e serenas. E, do outro lado, você.

38 O assassinato de John F. Kennedy (1917 - 1963), o trigésimo-quinto presidente dos Estados Unidos, ocorreu em uma sexta-feira, 22 de novembro de 1963, em Dallas, Texas, nos Estados Unidos. Kennedy foi mortalmente ferido por disparos enquanto circulava no automóvel presidencial na Praça Dealey. A ação do filme se passa em uma escola católica no Bronx, no outono de 1964. 


\section{(Irmã James espirra)}

\section{Garota}

Deus te abençoe, irmã.

\section{Irmã James}

Obrigada.

\section{Padre Flynn}

Eu quero contar uma história para vocês.

Um navio de carga naufragou uma noite. Pegou fogo e afundou. E somente um marinheiro sobreviveu. Ele encontrou um bote salva-vidas, improvisou uma vela e, de acordo com a disciplina náutica, voltou seus olhos para o céu e leu as estrelas. Ele definiu uma rota até a sua casa e, exausto, adormeceu. Nuvens encobriram o céu. Pelas 20 noites seguintes, ele não pôde mais ver as estrelas. Ele achava estar em seu curso, mas não havia como ter certeza. E, com os dias encobertos, e o marinheiro lançado ao mar, ele começou a ter dúvidas. Como ele iria definir seu curso corretamente? Ele ainda estava indo em direção à sua casa? Ou estava horrivelmente perdido e condenado a uma morte terrível? Não havia como saber. A mensagem das constelações, ele teria a imaginado devido às circunstâncias desesperadoras? Ou teria ele visto a verdade uma vez...

Irmã Aloysius (para um garoto que dorme sobre o banco da igreja)

Endireite-se! 


\section{Padre Flynn}

...e agora precisava se agarrar a ela sem mais confirmações?

Alguns de vocês na igreja hoje conhecem exatamente a crise de fé que eu descrevo. E eu quero dizer a vocês: a dúvida pode ser um vínculo tão poderoso e sustentador quanto a certeza. Quando vocês estiverem perdidos, vocês não estão sozinhos. Em nome do Pai, do Filho e do Espírito Santo, amém.

Por favor, levantem-se. 